I N T ER N ATIONAL MONETARY FUND

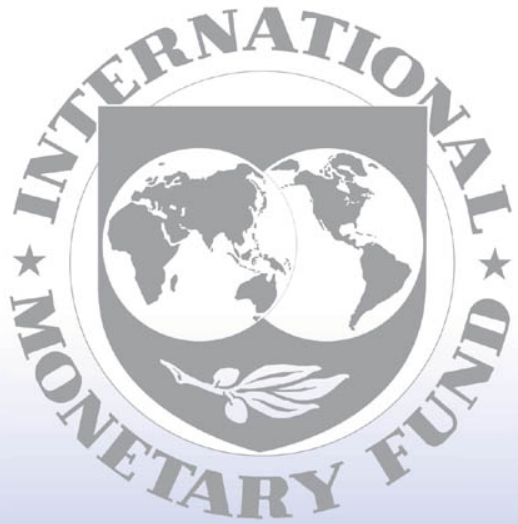

Staff

Country

Reports 


\title{
Azerbaijan Republic: 2001 Article IV Consultation, First Review Under the Poverty Reduction and Growth Facility, and Request for Waiver of Performance Criteria- Staff Report; Staff Supplement; Public Information Notice on the Executive Board Discussion; and Statement by the Executive Director for Azerbaijan Republic.
}

Under Article IV of the IMF's Articles of Agreement, the IMF holds bilateral discussions with members, usually every year. In the context of a combined discussion of the 2001 Article IV consultation with Azerbaijan Republic and First Review Under the Poverty Reduction and Growth Facility, and Request for Waiver of Performance Criteria, the following documents have been released and are included in this package:

- the staff report for the 2001 Article IV consultation and First Review Under the Poverty Reduction and Growth Facility and Request for Waiver of Performance Criteria, prepared by a staff team of the IMF, following discussions that ended on December 19, 2001, with the officials of Azerbaijan Republic on economic developments and policies. Based on information available at the time of these discussions, the staff report was completed on February 6, 2002. The views expressed in the staff report are those of the staff team and do not necessarily reflect the views of the Executive Board of the IMF;

- a staff supplement of February 6, updating information on recent economic developments;

- a Public Information Notice (PIN) summarizing the views of the Executive Board as expressed during its February 20, 2002 discussion of the staff report that concluded the Article IV consultation;

- a statement by the Executive Director for Azerbaijan Republic.

The document listed below has been or will be separately released.

\section{Selected Issues and Statistical Appendix}

The policy of publication of staff reports and other documents allows for the deletion of market-sensitive information.

To assist the IMF in evaluating the publication policy, reader comments are invited and may be sent by e-mail to Publicationpolicy@imf.org.

Copies of this report are available to the public from

Intemational Monetary Fund - Publication Services

$70019^{\text {th }}$ Street, N.W. - Washington, D.C. 20431

Telephone: (202) 623-7430 - Telefax: (202) 623-7201

E-mail: publications@imf.org Internet: http://Www.imf org

Price: $\$ 15.00$ a copy

\author{
International Monetary Fund \\ Washington, D.C.
}




\section{INTERNATIONAL MONETARY FUND}

\section{AZERBAIJAN REPUBLIC}

\section{Staff Report for the 2001 Article IV Consultation, First Review Under the Poverty Reduction and Growth Facility, and Request for Waiver of Performance Criteria}

Prepared by European II and Policy Development and Review Departments

Approved by Oleh Havrylyshyn and Martin Fetherston

February 6, 2002

Contents

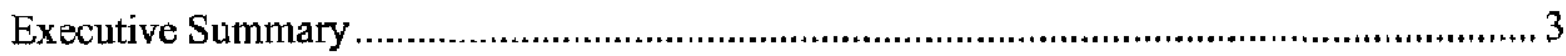

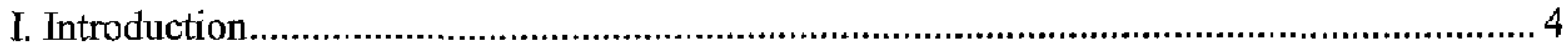

II. Recent Developments and Program Implementation ........................................................5

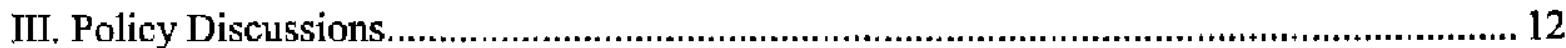

A. Macroeconomic Framework ......................................................................... 12

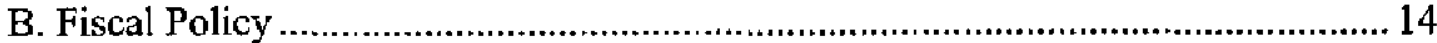

C. Monetary and Exchange Rate Policies and Financial Sector Reform ................... 18

D. Energy Sector Financial Discipline ................................................................. 20

E. External Sector Policies........................................................................................ 21

F. Poverty Reduction Strategy Paper .......................................................................21

IV. Balance of Payments and Capacity to Repay........................................................... 21

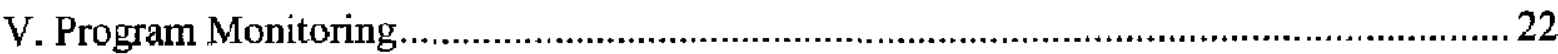

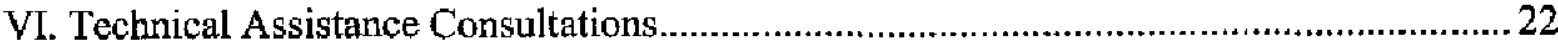

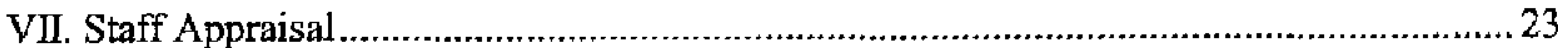

Text Boxes

Box 1. Structural Performance Criteria and Benchmarks, End-September 2000 ..............10

Box 2. Structural Conditionality Streamlining Assessment.............................................13

Box 3. Integration of SOCAR's Quasi-Fiscal Activities into the State Budget.................18 
Figures

1. Monetary Developments, 2001 6

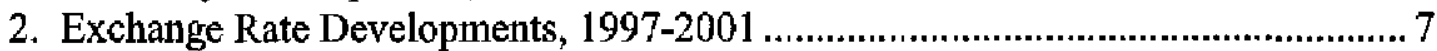

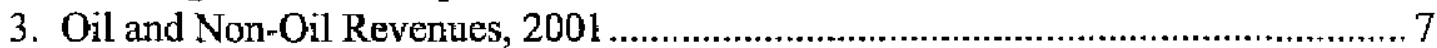

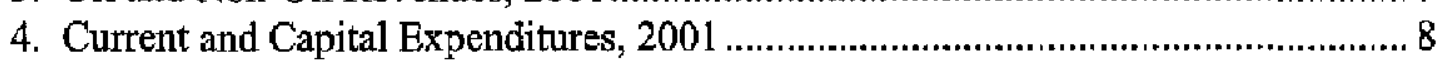

Tables

1. Selected Economic and Financial Indicators, 2000-2005 26

2. Quantitative Performance Criteria and Benchmarks for the PRGF, April 1, 2001 - December 31, 2002 …..................................................27

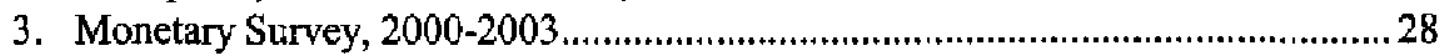

4. Summary Accounts of the Azerbaijan National Bank, 2000-2003 ....................29

5. Consolidated Government Operations, 2001-2003..............................................30

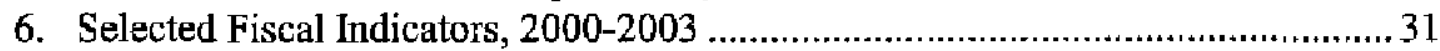

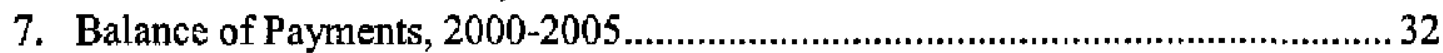

8. External Finaneing Needs and Sources ...............................................................33

9. Capacity to Repay the Fund, 1999-2005 ..........................................................34

10. Prior Actions for the Completion of the First Review, and Structural Performance Criteria and Benchmarks for end-March 2002 …................... 35

11. Review and Phasing of Disbursements Under the Proposed

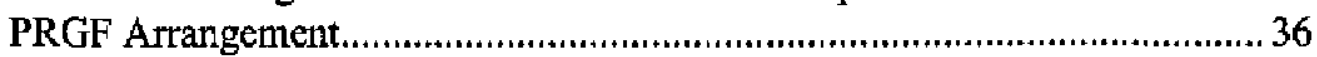

Appendices

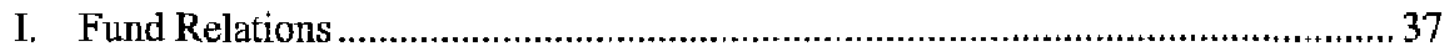

II. Relations with the World Bank ...................................................................41

III. Revision of Monetary Data .....................................................................43

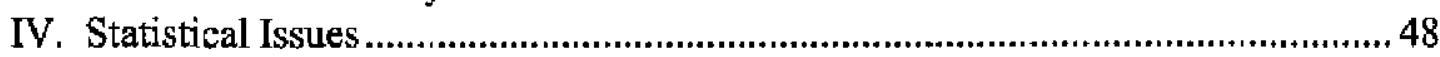

V. Technical Consultation Note .......................................................................... 51 


\section{EXECUTIVE SUMMARY}

\section{Background}

A three-year arrangement under the PRGF, in an amount equivalent to SDR 80.45 million (50 percent of quota) was approved on July $2,2001$.

\section{Performance under the program}

- Economic and financlal performance was satisfactory, and all quantitative performance criteria were met. Implementation of structural reforms was somewhat slower than programmed and the authorities are requesting waivers for nonobservance of three structural performance criteria for end-September 2001 and the continuous performance criterion on the stock of external arrears (now cleared). The adoption of regulations on the oil fund budget was done on time. The policies called for in the structural performance criteria on the revised law on the Chamber of Accounts, the removal of Azerbaijan National Bank (ANB) deposits from the International Bank, and the adoption of a reform program for the Customs Commitfee were implemented with delay.

- Real GDP growth was 9 percent, slightly above the program target, and end-year inflation was 1.3 percent. The external current account deficit was broadly unchanged from 2000 , at about 2.3 percent of GDP. Reserve money grew slower than programmed, and the manat depreciated by 4.2 percent against the U.S. dollar.

- Fiscal policy was tighter than programmed, with a consolidated government surplus of 1.5 percent of $\mathrm{GDP}$, compared with a program deficit target of 0.5 percent of GDP.

\section{Medium term prospects and outlook for 2002}

- Azerbaijan's medium-term prospects remain uncertain, the to uncertainties in both oil prices and energy sector jnvestments. Delays in these major energy sector investment plans would have a significant impact on Azerbaijan's balance of payments and growth prospects.

- For 2002, real GDP growth is projected at 8.5 percent, while the CPI is likely to increase by 3 percent. Because of lower oil prices, the external current aecount deficit is expected to be 5 percent of GDP worse than originally programmed.

- The 2002 budget projects a consolidated government deficit of 0.1 percent of GDP, and provides for adequate provisioning of utility consumption, increased social expenditures, and some of the implicit subsidies related to previous preferential tariffs. SOCAR will be granted a tax credit for the value of unpaid fuel deliveries to Azenergy and Azerigaz, and this tax credit and SOCAR subsidy will be included in the quarterly reports on budget execution.

- The government has adopted a comprehensive reform program in the energy sector, including measures to enhance payments discipline, improve the efficiency of the utility companies, accelerate privatization, unify domestic and world oil prices; and review and adjust utility tariffs. 


\section{INTRODUCTION}

1. Article IV consultation discussions, and discussions on the first review under Azerbaijan's PRGF arrangement, were held in Baku during December 6-19, 2001. ${ }^{1}$ Earlier missions (in August and November 2001) had focused on the 2002 budget and the government's energy sector reform plan. ${ }^{2}$

2. The Executive Board completed Azerbaijan's 2000 Article IV consultation on August 1, 2000 (EBM/00/79). Directors commended the authorities on macroeconomic policy adjustments that had helped reduce the impact of extemal shocks on output, while maintaining financial stability. Directors noted, however, that growth had been concentrated in oil and oilrelated sectors, and urged the authorities to accelerate structural reforms so as to assure sustained and broad-based growth, leading to a significant reduction in poverty. The last Board discussion on Azerbaijan (July 2, 2001) led to the approval of the PRGF arrangement, and the first disbursement thereunder, in an amount of SDR 8.05 million (Appendix I). ${ }^{3}$ At that time, the Directors commended the authorities on the continuing strong economic performance, including the acceleration of structural reforms since the expiration of Azerbaijan's previous PRGF/EFF arrangement. While welcoming the authorities' commitment to tackle the quasi-fiscal subsidies in the energy sector, Directors emphasized the importance of adopting a comprebensive program in this area, to underpin the economic stability already achieved and to facilitate a broadening of economic growth.

3. In the attached letter of intent (LOI) to the Managing Director, dated February 6, 2002 (Attachment I), the authorities discuss their performance under the PRGF arrangement to date and their planned economic policies for 2002, and propose performance criteria, indicative targets and benchmarks for end-March and end-June, as weil as quantitative performance criteria and indicative targets for end-September and end-December 2002. Azerbaijan continues to avail itself of the transitional arrangements of Article XIV. However, the

\footnotetext{
I The mission consisted of Mr. Wakeman-Linn (head), Messrs. Abdoun and van Selm (EU2), Ms. Aturupane (PDR), Mr. Danninger (FAD), Mr. Surin (interpreter, BLS) and Ms. Manapsal (staff assistant, EU2). The mission was assisted by Mr. Mered, the Fund resident representative, as well as by Mr. Khan, the Fund resident treasury advisor, and Mr. Barrand, the Fund resident tax administration advisor. The mission met with the President, Prime Minister, National Bank Governor, Minister of Finance, Minister of Economic Development, other senior officials, and representatives of the diplomatic community. Mr. Siegenthaler (Assistant to the Executive Director) participated in several meetings with the authorities.

${ }^{2}$ In addition to the people noted above, the August mission included Mr. Wolfson (ICM) and Mr. Fletcher (FAD), while the November mission included Mr. Symansky (FAD).

${ }^{3}$ Relations with the World Bank are set out in Appendix II.
} 
authorities have indicated their intertion to accept the obligations of Article VIII, sections 2, 3, and $4 .^{4}$

\section{RECENT DEVELOPMENTS AND PROGRAM IMPLEMENTATION}

4. Economic developments in 2001 were in line with program projections. Despite the shocks to the international economy, and the resulting reduction in oil prices, real GDP growth was an estimated 9.0 percent, exceeding the program target of 8.5 percent, with substantial growth occurring in virtually all sectors of the economy (Table 1).

5. Financial policies were somewhat tighter than programmed. All quantitative performance criteria for end-September 2001 were met (Table 2), Notwithstanding the greater-than-projected increase in net international reserves of the Azerbaijan National Bank (ANB), reserve money grew somewhat slower than programmed and broad money growth was broadly in line with program targets (Tables 3 and 4). ${ }^{5}$ However, dollarization continued, as foreign currency deposits increased to over 42 percent of total broad money, up from 37.5 percent at end-2000. As a result, total broad noney grew faster than programmed (Figure 1).

\footnotetext{
${ }^{4}$ Discussions continue on minor issues that ned to be resolved before Azerbaijan can accept the obligations of Article VIII.

${ }^{5}$ There have been a number of changes in the monetary accounts since the approval of Azerbaijan's PRGF arrangement, including a previously articipated reclassification of accounts to more correctly capture net credit to government; the revocation of Agroprom's banking license, and the resulting removal of its loans from bank credit and the ANB's claims on Agroprom from credit to banks; and the removal of oil fund deposits from the monetary survey. The "program" figures cited in the tables for this paper are the original Boardapproved figures, adjusted for these accounting changes. Appendix III provides a detailed explanation of the derivation of these adjusted program figures.

${ }^{6}$ The staff and the authorities are both uncertain about how to explain the continually increasing leve] of dollarization, particularly in light of the macroeconomic stability of recent years, the relatively healthy reserve position of the central bank, and the modest and fairly steady rate of depreciation of the manat in the last two years. However, it is suspected that it may be related to the large and growing role of oil-a dollarized industry-in Azerbaijan's economy. The staff will continue to examine this issue with the authorities. It should also be noted that, because of a lack of information on cash foreign exchange in circulation, the dollarization figures cited above may not accurately reflect the trends in total foreign exchange holdings as a share of broad money.
} 
Figure 1. Azerbaijan: Monetary Developments, 2001

(12-month percent change, end of period)

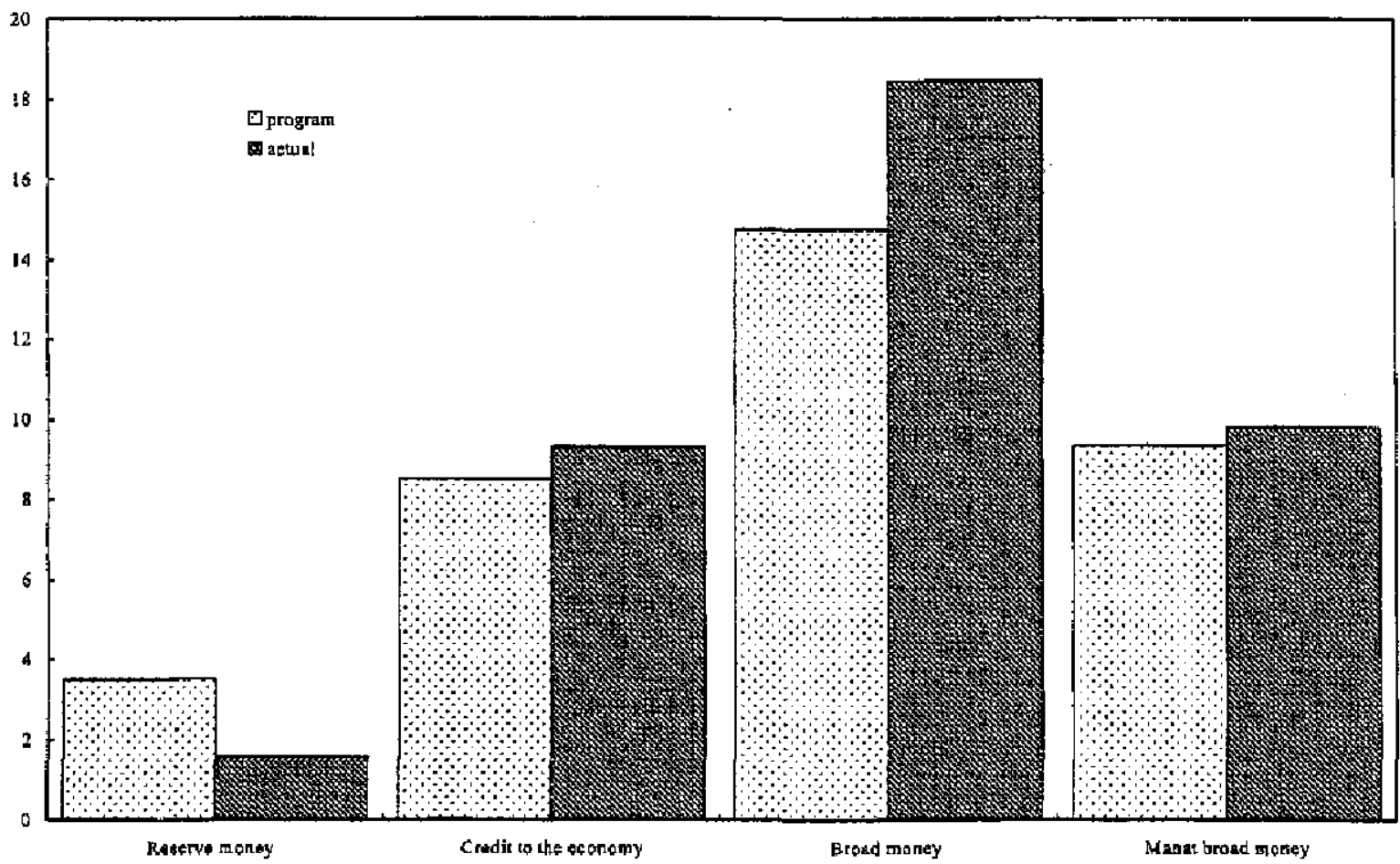

6. The ANB continued its policy of managed float of the manat, intervening on both sides of the market, as necessary, to smooth out temporary fluctuations in the exchange rate, but not resisting persistent exchange rate pressures. This led to a 4.2 percent depreciation of the nominal exchange rate, and a slight real depreciation (Figure 2) in 2001.

7. Fiscal policy was similarly tighter than programmed, with a consolidated government surplus of 1.5 percent of GDP, compared to a program deficit target of 0.5 percent of GDP (Tables 5 and 6). This surplus occurred despite a modest shortfall in revenues ( 0.7 percent of GDP, Figure 3 ), due in part to the abandonment of negotiated tax targets for large state-owned enterprises, and was necessitated by a shortfall in several financing items (a delay in the World Bank SAC-I, lower than projected privatization proceeds and treasury bill sales, and slower than anticipated disbursal of foreign project loans). The authorities responded to this shortfall in financing by reducing foreign-financed capital expenditures and constraining wages (largely through a postponement of a planned wage increase) and expenditures on goods and services (Figure 4). Despite these shortfalls, for the year the government avoided accumulating arrears on non-utility expenditures, and thus appears to have adhered to the end-December indicative ceiling on such arrears. ${ }^{8}$

${ }^{8}$ As noted in the LOI (paragraph 2), the end-June indicative ceiling on non-utility arrears was exceeded by a modest amount (manat 74 billion); by end-September this had been reduced to manat 8 billion, and by end-October it had been eliminated. 
Figure 2. Azerbaijan: Exchange Rate Developments, 1997-2001

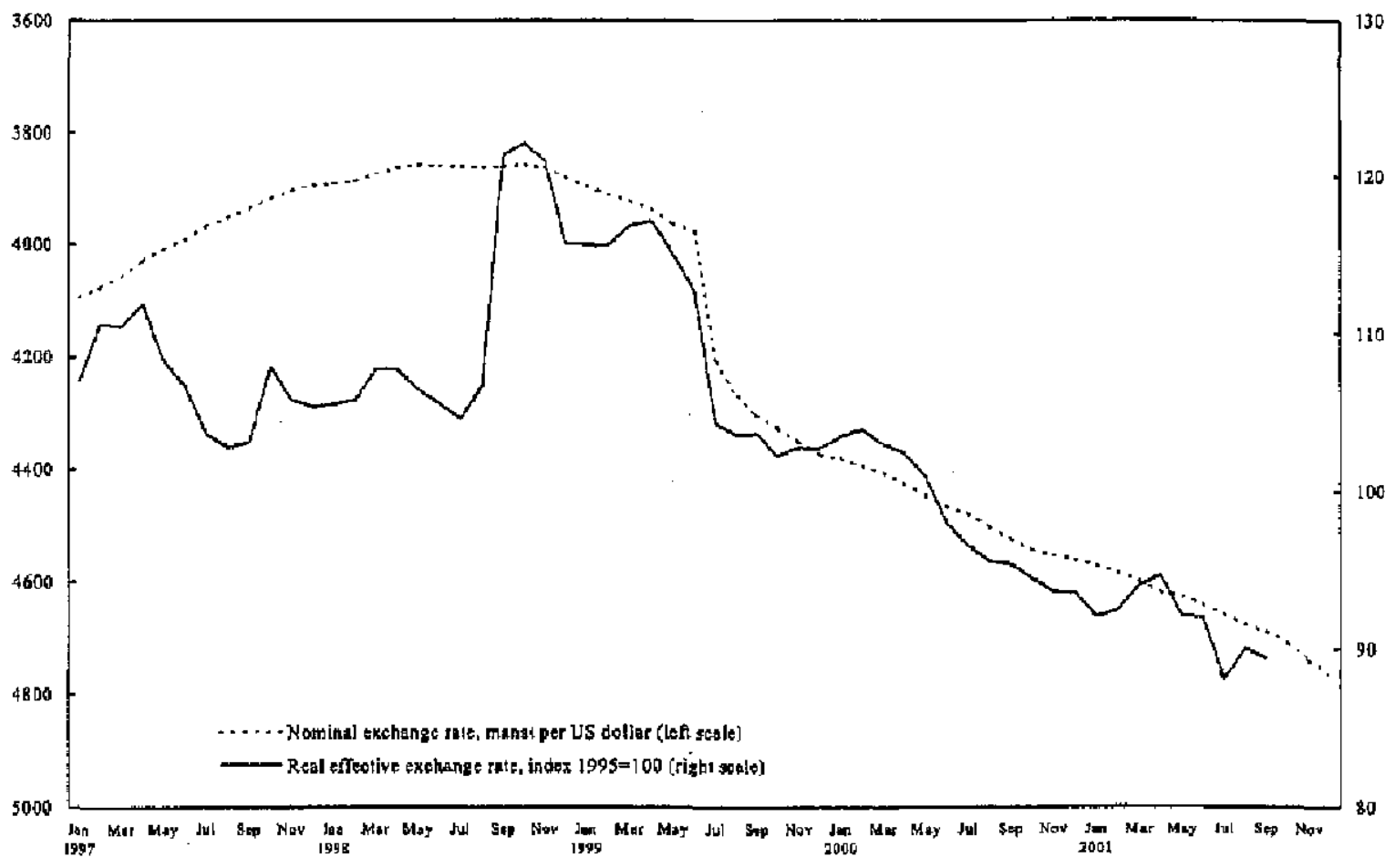

Figure 3. Azerbaijan: Oil and Non-Oil Revenues, 2002

(In percent of GDP)

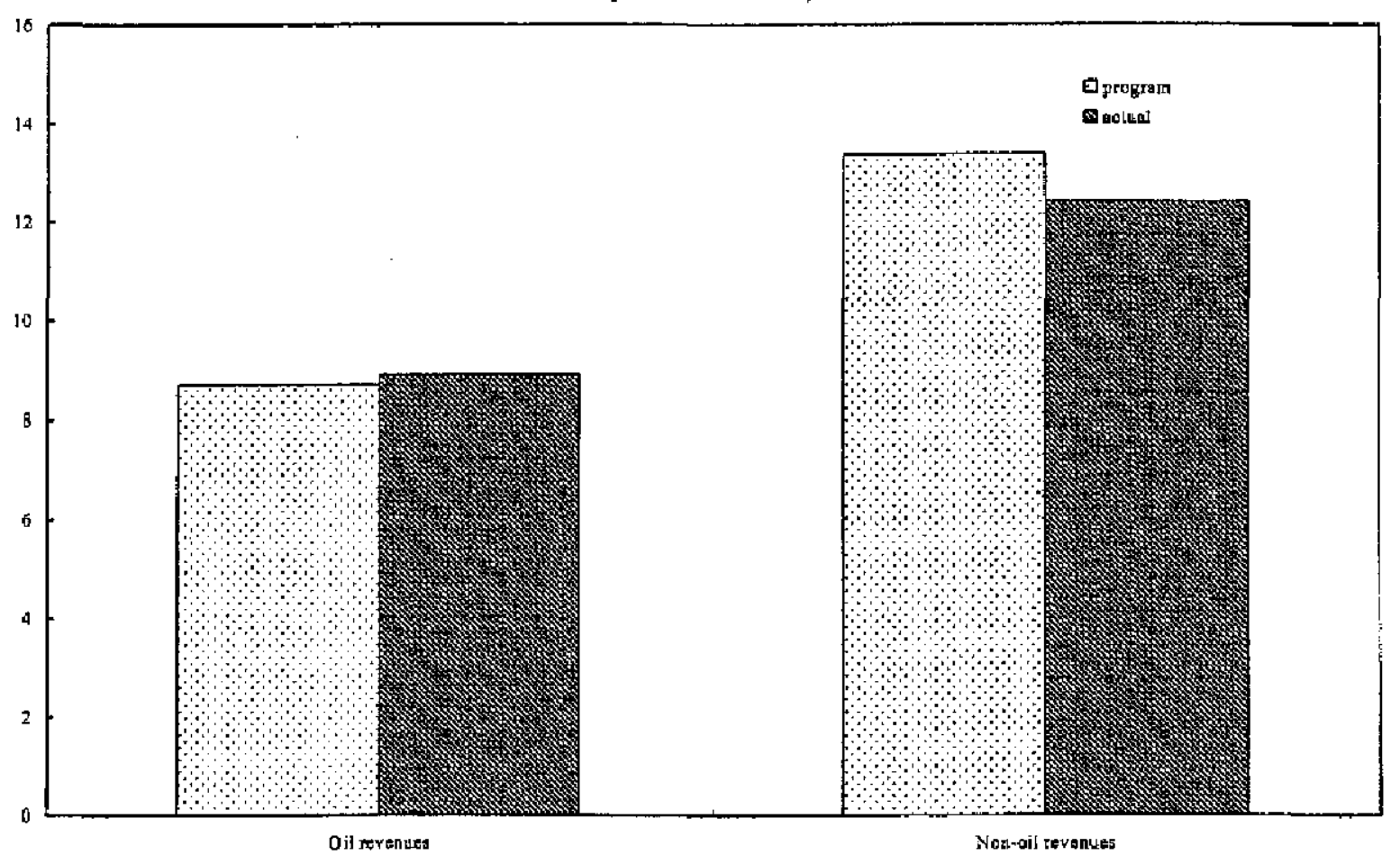


Figure 4. Azerbaijan: Current and Capital Expenditures, 2001

(Annual Percentage Change)

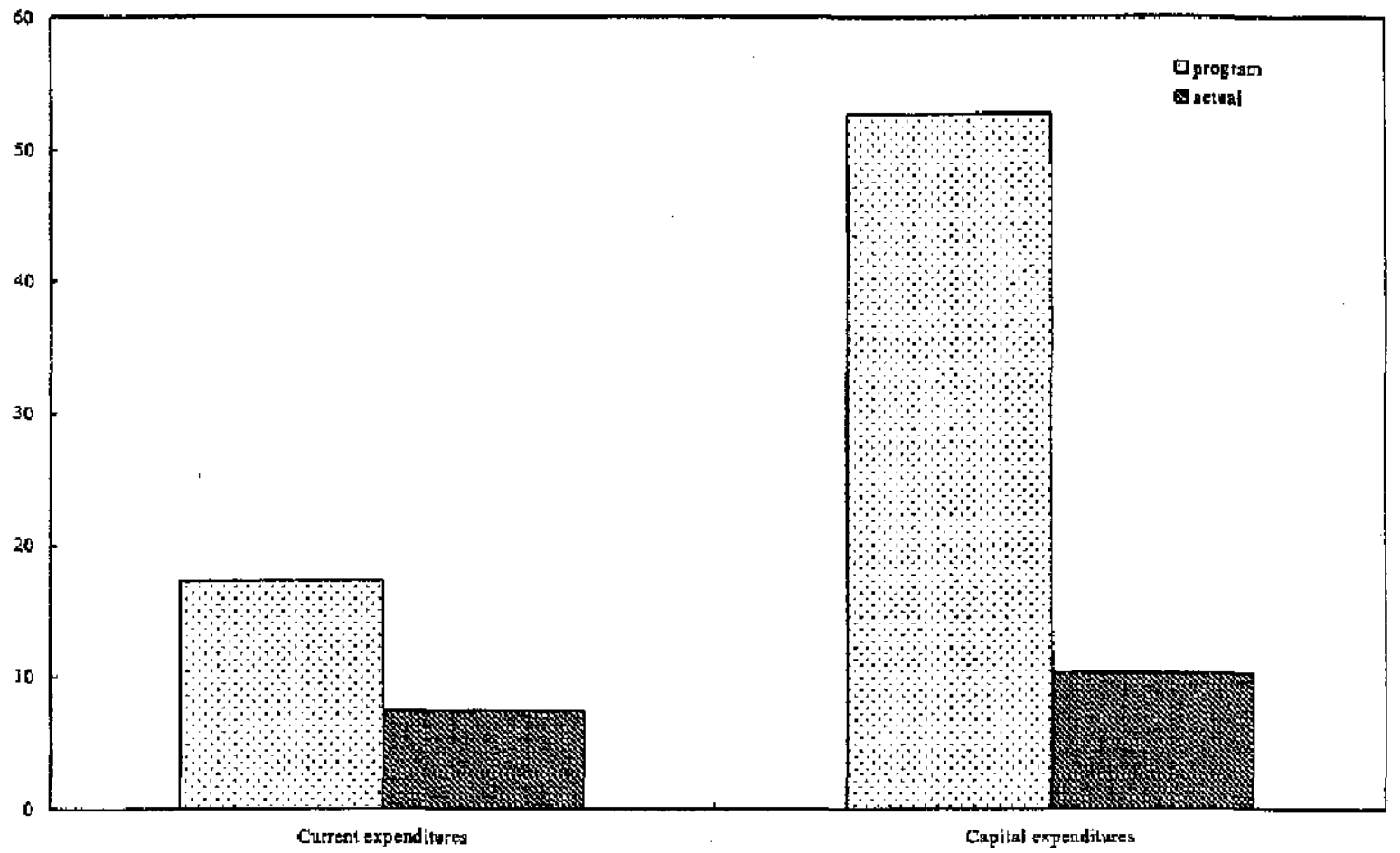

8. As a result of the tighter-than-programmed financial policies, inflation was slightly lower than programmed, with an end-period consumer price inflation rate of 1.3 percent, compared to the program target of 2.5 percent.

9. The external eurrent account deficit was broadly unchanged from 2000 , at an estimated 2.3 percent of GDP (Table 7). This smaller-than-programmed deficit was due to lower non-oil imports. This in turn was the result of the tight financial policies, strong agricultural production-which reduced food imports-and the fact that the $2000 \mathrm{import}$ total included substantial, one-time imports. ${ }^{9}$ While the improvement in the overall balance of payments, relative to projections, was somewhat less than for the current account-largely due to lower-than-projected public sector borrowing-the increase in gross reserves of the ANB was nonetheless US\$49 million more than programmed.

10. Azerbaijan became in violation of the continuous performance criterion on the stock of external arrears on October 1,2001 , as a US $\$ 1.7$ million government loan due to Uzbekistan on that date was not paid, pending resolution of a related debt for goods delivered by Azerbaijan to Uzbekistan. The Azeri authorities have since paid all but US\$520,000 of the outstanding amount. This balance is equal to the value of the goods previously delivered by an

${ }^{9}$ In 2000 , imports included two aircraft (US $\$ 130$ million), as well as a vessel (US\$32 million) for repair and re-export. Excluding these items, 2001 non-oil inports grew about 5 percent. 
Azeri enterprise to Uzbekistan, the value of which (according to the original contract) was to be applied to the state debt of Azerbaijan to Uzbekistan. The Azeri authorities thus consider this debt paid in full, while the Uzbeks have not yet agreed to this view. The staff has urged the authorities to resolve this issue as quickly as possible. ${ }^{10}$

11. Azerbaijan has continued to make substantial progress on structural reforms. All four policy actions subject to structural performance criteria, as well as those subject to benchmarks for end-September 2001, have been fulfilled, albeit in some cases more slowly than programmed (Box 1). The adoption of regulations on the oil fund budget was done by the end-September deadline. Through the combination of a presidential decree and a memorandum of understanding between the Ministry of Finance and the Oil Fund, the authorities have adopted procedures that ensure the preparation, execution, audit and reporting of a consolicated fiscal position.

12. A revised law on the Chamber of Accounts--designed in close cooperation with the staffs of the World Bank and the Fund-was approved by parliament in December 2001. However, delays in the preparation of this law led to its being submitted to parliament in November, after the end-September date specified in the performance criterion.

\section{Similarly, the ANB has removed all deposits from the International Bank and} adopted a regulation prohibiting such deposits in the future. "However, there was a delay in the elimination of two small accounts in Iranian rials. While the value of such deposits was reduced from about US $\$ 65$ million at end-2000 to less than the equivalent of US $\$ 2,000$ by end-September, the failure to eliminate these accounts by that date (they were subsequently closed in October) was a technical violation of the performance criterion.

14. Finally, delays beyond the control of the authorities prevented them from implementing the final structural performance criterion-adoption of a comprehensive reform program for the Customs Committee-by end-September, as called for in the program. The reform program was to be based on the results of an independent external evaluation of the Committee; the first tender to select the company to conduct this evaluation closed with only one bidder. Since Azeri law requires a minimum of three bids for a tender to be valid, the tender had to be rerun, and the winner of the tender was chosen in early October 2001. The draft report was delivered to the authorities, and shared with the Fund staff in midJanuary. Based on that report, and following consultations with Fund staff, the authorities have now adopted a comprehensive reform program for the Customs Committee, as described in the LOI (paragraph 9).

\footnotetext{
${ }^{10}$ For program purposes; this amount is treated as in dispute, and not as arrears.

${ }^{11}$ In the context of amending the Central Bark Law in 2002, the authorities intend to include a provision that will prohibit the ANB from holding deposits in institutions that it regulates.
} 
15. Two structural benchmarks were implemented on time: the adoption of regulations for the implementation of the new tax code, and the inclusion in the draft 2002 budget of adequate funding for the Chamber of Accounts. While the authorities had not adopted a comprehensive program to strengthen financial ciscipline in the energy sector by end September (the final structural benchmark), they have, as explained below, now adopted a strong and comprehensive reform program in this area.

\begin{tabular}{|l|l|l|}
\hline \multicolumn{2}{|c|}{ Box 1. Structural Performance Criteria and Benchmarks } \\
End-September 2001
\end{tabular}


16. Stractural reforms continue in other areas as well. In the banking sector, building on the results of the diagnostic study of commercial banks, the ANB has strengthened its banking supervision efforts, including through the closure of five banks, the announcement of an increase in the minimum capital requirement (from US\$2 million to US\$2.5 million), ${ }^{12}$ the strict enforcement of prudential standards, and the close monitoring of troubied banks. A revised Law on Banks is being prepared, in consultation with MAE and LEG, and is expected to be submitted to parliament in the first quarter of 2002. The ANB has continued to improve the operations of the payments system, is making progress on the design of an improved small-value payments system, and has substantially strengthened its internal operations, including in particular its accounting and audit departments. ${ }^{13}$ Finally, the ANB, in cooperation with MAE, has conducted a study of factors inbibiting competition in the banking sector. In the coming months, in consultation with the Fund and World Bank staffs, the authorities will develop an action plan to address these factors. As a first step, the ANB has increased the ceiling on the foreign share of banking sector capital, from 30 to 50 percent of the total, and will consider eliminating the ceiling entirely by the end of 2002 .

\section{With regard to structural reforms in the fiscal area, the government has made} significant progress in addressing the recommendations in the 2000 Report on the Observance of Standards and Codes (ROSC) (Supplement 1). A revised Budget Systems Law has been prepared, in close consultation with the staffs of the World Bank and the Fund, which will greatly increase the level of detail in the budget, as well as the information provided to parliament and the public. They have also continued progress on computerization of the treasury system. As part of the effort to streamline the budget system, starting January 1, 2002, the Disability and Employment Funds have been merged with the Social Protection Fund, and their transactions will be executed by the treasury. Work has continued on the development of a Medium Term Expenditure Framework (MTEF), and the authorities have decided that, starting in 2003, all capital expenditures by the state and oil fund budgets must come from a government-approved Public Investment Program (PIP). Work on the preparation of a PIP has begun, with the assistance of the World Bank.

18. There has been continued progress in tax administration, including through the strengthening of the Large Taxpayer Unit and increased reliance on no-contact filing. Most important, the government has succeeded in moving away from negotiated tax payments for large state-enterprises (except for the state oil company, SOCAR, for reasons discussed below), and now requires all taxpayers to pay taxes based on their legal liabilities.

\footnotetext{
${ }^{12}$ The staff had been expecting a more substantial increase in the capital requirement, in support of the ANB's goal of encouraging consolidation in the banking sector.
}

${ }^{13} \mathrm{~A}$ safeguards assessment of the ANB is underway. A Stage One report was approved by management on December 14,2001. Based on the preliminary findings of that report, an onsite assessment was conducted from January 7-18, 2002. A number of minor safeguards issues were identified and discussed with the authorities. 
19. Finally, progress continues in other areas, including efforts to enhance governance. Important reforms initiated in 2001 include the strengthening of the organization and authority of the Chamber of Accounts, the passage of an improved procurement law, the development of an anti-corruption law, which includes a requirement for asset and income declaration by government officials (and which has passed the first reading in pariiament), and accelerated progress in privatization (notably the signing of a long-term management contract for the Baku electricity distribution network). In many of these areas, the authorities have worked in close cooperation with the World Bank.

20. Azerbaijan continues to provide the Fund staff with timely and broadly accurate economic statistics. While problems remain with these statistics (Appendix IV), the authorities are working to strengthen them, and the staff is satisfied that the existing statistics provide a satisfactory basis for assessing economic developments in Azerbaijan. Provision of data to the Fund on international reserves, foreign currency liquidity and external debt falls short of the detail in the Special Data Dissemination Standard (SDDS) benchmarks established for surveillance purposes.

\section{Policy Discussions}

\section{A. Macroeconomic Framework}

21. The staff and authorities agreed there was a need to adjust the program's envisioned macroeconomic framework for 2002, in light of the much lower oil price forecasts compared to those anticipated at the time the three-year PRGF arrangement was originally approved. ${ }^{14}$ However, given the strong macroeconomic performance in 2001 , with significant growth across all sectors, and the anticipated acceleration in oil sector investments in 2002, it was agreed that real GDP growth for 2002 was likely to be unchanged from the original program projections, and would again be broad-based. ${ }^{15}$

22. Price developments are subject to two contradictory pressures. On the one hand, the substantial decline in oil prices is projected to lead to a decline in the GDP deflator of 3 percent. With regard to consumer prices, however, planned adjustments in the domestic price of energy products (discussed below) mean that the CPI is likely to increase somewhat faster than originally targeted for 2002; thus the staff and authorities have agreed on a target for consumer price inflation of 3 percent.

\footnotetext{
${ }^{14}$ The projections assume an average price of oil of US\$19 per barrel for 2002, consistent with the World Economic Outlook (WEO) forecast at the time of progran review discussions, compared to US $\$ 24.40$ at the time of the original program approval. For $2003-05$, the projections assume a price of US $\$ 20$ per barrel, reflecting the latest WEO forecasts.
}

${ }^{15}$ The structural content of the program is described in Box 2 . 
23. Investment prospects are largely unchanged from original projections. Two of the three major energy sector investments-the Baku-Tbilisi-Ceyhan (BTC) main oil export pipeline, and the first phase of full field development of the Azeri-Chirag-Guneshli (ACG) oil fields-are proceeding largely as anticipated, and major investments are expected during 2002-04. The third project-the Shah Deniz gas field and associated export pipeline--has been delayed by difficulties in reaching certain agreements, most notably a transit agreement with Georgia. The most important agreements have now been reached.

\section{Box 2. Structural Conditionality Streamlining Assessment}

1. Coverage of Structural Conditionality in the Program

Structural Conditionality for end-March 2002 covers the following:

- fiscal poltcy, through a structural benchmark on the new Budget Systems Law. The conditionality is relevant for the fiscal objectives of the program;

- banking sector, through a performance criterion and a structural benchmark. The conditionality is critical to safeguard the integrity of the banking system and to establish a level playing field in the banking sector;

- trade pollcy, through a structural performance criterion. Further liberalization of the trade regime is essential for the balanced development of Azerbaijan's economy:

- energy sector, through a prior action and a structural performance criterion. Arrears and nonpayments in the domestic energy sector pose a serious potential threat to medium-term macroeconomic stability;

- governance issues, through a prior action on both the Chamber of Accounts and the Customs Committee, and a structural benchnark on the Customs Committee. Making Azerbaijan's stupreme audit institution operational is a central element of the effort to improve governance, as is the reform program for the Customs Committee.

2. Status of Structural Conditionality from Earlier Programs

Azerbajjan's previous Fund program expired in March 2000 without completion of the final review, because six key structural measures were not implemented. The six measures were: (1) completion of an external audit of SOCAR, (2) approval of the new Tax Code, (3) adoption of a new privatization program, (4) adoption of the Civil Service Law, (5) submitting a plan on the restructuring of the Cabinet of Ministers, and (6) merging three state-owned banks. All these measures were fully implemented at the time of Board approval of the current program, in July 2001. All structural performance criteria and benchmarts under the current program for endSeptember 2001 have also been implemented - see Box 1 .

3. Structural Areas Covered by Bank Lending and Conditionallty

The World Bank is currently identifying a reform program and the correspording policy measures that could be part of a structural adjustment credit to be approved in the first quarter of 2002. The credit components being identified include reforms in the (i) public sector; (ii) social sectors; (iii) financial sector; (iv) eliminating the quasi-fiscal deficit in the utilities sectors; ( $v$ ) industrial privatization; and (wi) privatization and regulatory reform in the utilities sectors. Key policy measures will be selected as prior actions before presenting the proposed credit to the Board. The EBRD plays an important role in banking sector reform.

4. Other Relevant Structural Conditions not Included in the Current Program Contrary to the previous program, the current program does not include conditionality on privatization. The World Bank takes the lead on this issue. 
24. The balance of payments projections have changed due to two major factors. The first is the decline in oil prices, which will contribute to an almost 26 percent deterioration in Azerbaijan's terms of trade in 2002. The second important, but less significant, factor is the lower-than-anticipated imports in $2001,{ }^{15}$ which led to lower import forecasts. Overall, the current account deficit is thus expected to be US $\$ 285$ million, or 5 percent of GDP, worse than originally projected. Roughly one third of this is due to higher oil imports, which will be financed by the investors. Most of the rest will be directly offset by lower capital repatriation by oil companies, leading to a projected US $\$ 103$ million decline in the balance of payments, most of which will be reflected in a lower build up of oil fund assets.

25. Azerbaijan's medium-term prospects remain highly uncertain, due to both oil prices and energy sector investments. While the degree of uncertainty related to those investments has eased in the last 9 months, substantial delays-particularly of the Shah Deniz investment plans-cannot be ruled out. Such delays would have significant impacts on Azerbaijan's balance of payments and growth prospects. Further declines in the price of oil could complicate fiscal policy, as each US\$1 decline in the price of a barrel of oil costs the state budget an estimated 170 billion manat, or 0.5 percent of GDP, in revenue.

\section{B. Fiscal Policy}

26. Discussions on fiscal issues focused on revenue projections and planned tax policy changes, utility consumption by budgetary organizations, the explicit incorporation into the 2002 budget of subsidies for utility consumers (to replace abolished preferential tariffs), and the incorporation into the 2002 budget of the implicit subsidies previously provided to the utility companies (Azerenergy and Azerigas) by the SOCAR.

27. Overall, these policies are expected to lead to a general government deficit (excluding the oil fund) of 2.7 percent of GDP, compared to 3.4 percent of GDP in the original program, and a consolidated government deficit of 0.1 percent of GDP. The major source of financing for the general govemment deficit (almost two-thirds of the total) will be external project loans. Other major sources of financing will be a planned disbursement from the World Bark's SAC and privatization proceeds (each about 0.5 percent of GDP), with modest treasury bill financing anticipated.

\section{Revenues}

28. The authorities proposed a wide range of tax policy changes for 2002. The staff supported plans to reduce the payroll tax rate from 33 to 29 percent (previously, the combined tax on wages, including the income tax, could reach as high as 63 percent). Understanding was also teached on reducing the number of brackets and the rates for the income tax, paid for by

${ }^{15}$ The original projections for 2001 imports did not adjust for the one-time imports. 
the elimination of a deduction for large families. Finally, understandings were reached on the elimination of the opportunity to deduct investments from company profits twice. ${ }^{16}$

\section{The authorities had contemplated a more substantial reduction in income tax} rates, as well as a reduction in the enterprise proflt tax. The staff urged caution, bowever, particularly in light of the fact that data constraints limit the authorities' ability to estimate the impact of tax policy changes on revenue projections. In the end, the authorities agreed with the need for caution and will carefully consider additional tax reductions in 2003. Also, the authorities reduced the VAT threshold by about two thirds, against staff advice on this issue, as they felt the government was losing substantial revenue due to the high threshold. The staff is not persuaded that they will generate additional revenue from this reform, and continue to urge the authorities to undo this tax policy change.

30. Based on these new tax policies, the mission held extensive discussions on the revenue forecasts for 2002. With regard to taxes from SOCAR (oil revenues), a careful evaluation of the company's cash flow prospects, in light of the new oil price projections, sbows that the company will not be in a position to pay its tax liabilities in full in cash. ${ }^{17}$ Nonetheless, a reduction in non-essential expenditures (in part related to the privatization of selected noncore activities), as well as the full-year effects of the scheme to replace fuel oil with natural gas in electricity production-thereby freeing up oil for exports-means SOCAR should be able to pay about manat 340 billion more in taxes in 2002 than in 2001.

31. Non-oil revenue is expected to increase by 1.4 percent of GDP, as the combination of GDP growth (nominal non-oil GDP is projected to grow 9 percent), the revenue impact of the energy sector investments, the full-year effect of imposing VAT on the destination basis, and the revised depreciation rules are expected to lead to a significant increase in revenues.

\section{Expenditures}

32. Expenditure policy changes in $\mathbf{2 0 0 2}$ have been largely driven by four factors: the need to ensure that budgetary organizations pay in full for their utility consumption; the incorporation into the budget of some of the previously implicit subsidies related to preferential utility, gas and transport tariffs; the desire to increase expenditures on health, education and social protection; and continuation of the policy of decompressing the government wage scale.

\footnotetext{
${ }^{16}$ Prior to this, all investments were eligible for 100 percent expensing, and some were also eligible for depreciation (despite the fact that they had already been expensed). The new system eliminates expensing, while allowing accelerated depreciation for some investments.

${ }^{17}$ The major reason is that SOCAR will be delivering natural gas and fuel oil to the utilities worth roughly manat 1.7 trillion, but will receive virtually no payment in return. This issue is addressed in the context of discussions on the implicit subsidies, below.
} 
33. Prior to 2002, budgetary organizations have routinely run arrears on utility consumption. In the 2002 budget, a substantial (manat 53 billion) increase was made in allocations for utility consumption by budgetary organizations. This new allocation would have fully covered utility consumption in 2001 . In addition, a presidential decree calls for the termination of service to budgetary organizations that attempt to consume beyond approved limits, and holds heads of such organizations responsible for any over-consumption.

34. Also prior to 2002, many consumers benefitted from half-price or free gas, electricity and transport. Effective January 1, 2002, all such preferential tariffs have been eliminated. For needy consumers (orphans, refugees, internally displaced persons (IDPs), and pensioners), the equivalent subsidy will be provided explicitly through the budget; this measure will cost 144 billion manat. In addition, as all uniformed personnel had previously been entitled to free transport throughout the country, the elimination of these benefits has been combined with an offsetting increase in their wages.

35. Third, consistent with their commitments in the Interim Poverty Reduction Strategy Paper (I-PRSP), the government has increased expenditures on education, health and social protection. Combined budgeted expenditures in these throe categories have increased by roughly 0.7 percent of GDP relative to 2001 . Finally, the continuation of the policy of decompressing the civil service wage scale, plus the effect of the increased wages for uniformed personnel discussed above, will result in wage increases in 2002 totaling some manat 354 billion.

36. In addition to these state budget expenditures, the oil fund will begin significant capital expenditures in 2002. (In 2001, oil fund expenditures were limited to operational expenditures and a very modest amount-less than 0.1 percent of GDP—of capital expenditures.) Roughly manat 150 billion will be spent by the oil fund to constnuct houses and improve agricultural and other infrastructure facilities for refugees and IDPs.

\section{Incorporation Into the Budget of the SOCAR Subsidies to Azerenergy and Azerigas}

37. In their original Memorandurn of Economic and Financial Policies (MEFP), the authorities indicated their intention to terminate the practice of asking SOCAR to provide fuel to Azerenergy and Azerigas without payment. Instead, they would explicitly include any subsidies to be provided to Azerenergy and Azerigas in the state budget, starting in 2002 (EBS/01/91, Attachment III, paragraph 14). However, in discussions on the 2002 budget, the authorities were reluctant to adopt this reform measure.

38. The authorities had essentially two concerns. First, they feared that if the budget explicitly subsidized the energy consumption of Azerenergy and Azerigas, It would create a moral hazard problem, sending a signal to consumers that they need not pay their utility bills, since the government was covering the cost. Second, they were reluctant to cover the full costs of these companies, as they feared that a significant portion of those costs reflected waste, inefficiency, and theft. 
39. The staff argued that, if this reform were part of a comprehensive program to enhance financial discipline in the energy sector, rather than reducing the incentive for consumers to pay, it would give the government a strong argument for enforcing such payments. Under the system prevailing through 2001, no one appears to pay for the fuel costs of Azerenergy and Azerigas. In reality, however, the staff noted that the budget was already bearing the burden of these subsidies: since SOCAR was not paid by the utilities, SOCAR in turn could not pay its full legal tax liabilities. The value of these implicit subsidies in 2001 was roughly equal to the shortfall in SOCAR's tax payments.

40. If the government explicitly incorporated these subsidies into the budget, and SOCAR were to pay its full legal tax liabilities, it would be clear to everyone how much the government was paying to subsidize utility consumption. ${ }^{19}$ The government could then argue that people should pay their utility bills, since this would reduce the needed subsidies and free government revenue for other, more vital, expenditures. With regard to waste and theft, the staff noted that these costs were also already being borne by the budget; making them explicit would increase the pressure to reduce such unnecessary costs.

41. The authorities agreed to these arguments, in the context of a comprehensive energy sector reform program (discussed below), but proposed a phased scheme. In 2002, while these subsidies will not be explicitly included in the approved state budget, they will be handled as detailed in the LOI, paragraph 11 and Box 3. A presidential decree to this effect has been issued, and the government has publicly acknowledged the implicit subsidy for 2000 and 2001 and the projected subsidy for 2002 . Adhering to these commitments throughout 2002 will be a structural performance criterion (LOI, paragraph 14).

\section{Oll Fund}

42. Now that the asset management and budget rules for the oil fund have been adopted, the staff and authorities have agreed it is time to turn attention to two additional issues. First, whille the rules for the oil fund require that its expenditures come from a governmentapproved MTEF and PIP, the government has not yet produced such documents. The government aims to produce them for the first time in 2002, in consultation with the staffs of the World Bank and the Fund, and to ensure that they are meaningful, prioritized documents.

43. Second, it is now time to make decisions about how the oil fund fits into the government's medium-term development plans. The staff urged the authorities to begin thinking about rules for determining the level and composition of spending from the oil fund over time, to ensure that the oil fund expenditures fit into a coherent consolidated budget that contributes to the government's medium term development objectives. While the authorities indicated a willingness to address these questions, they were not yet prepared to engage the staff in a meaningful discussion of the issues involved. Discussions on these issues, as well as

\footnotetext{
${ }^{19}$ The implicit subsidies in this form in 2001, for example, were more than 6 times actual health expenditures, and almost double actual education expenditures.
} 
the importance of eventually formally integrating the state and oil fund budgets, will continue in the coming months. 20

\section{Box 3. Integration of SOCAR's Quasi-Fiscal Activities Into the State Budget}

A key provision of the govemment's comprehensive energy sector reform plan is the integration of SOCAR's quasi-fiscal activities into the state budget. However, given the size of these subsidies, it is impossible simply to have the budget cover them in cash. As a result, in cooperation with $F A D$, the government has adopted a gradual plan for the incorporation of these subsidies into the budget.

In 2002 the government will assess through on-site monitoring the utilities' energy use and their ability to pay for inputs. The unpaid energy inputs will be declared a subsidy at the end of each quarter, with SOCAR granted a tax credit for this subsidy, and the subsidy and tax credit will be included in quarterly public reports on budget execution. Beginning in 2003 the government will formally incorporate the energy subsidy into the state budget.

Initially, the energy subsidy and associated tax credit will be executed via a non-cash book-entry scheme: the government will record the value of unpaid energy input as a subsidy and simultaneously credit SOCAR with a tax payment for the same amount. In 2002, to avoid an impact on the cash budget, the tax credit would only apply toward SOCAR's tax debt and that part of its current obligations that SOCAR is not expected to pay in cast.

As the government's energy sector financial discipline scheme takes hold, this should lead to increased collections by the utilities and thus increased cash payments by them to SOCAR. The size of the subsidy will decline, and SOCAR will be able to pay its full tax obligation in cash.

\section{Monetary and Exchange Rate Policies and Financial Sector Reform}

\section{The staff and authorities agreed that the thrust of monetary policy has been} sound in recent years, and that there is no need for a change in the basic direction of policy. The ANB will continue to target a low level of consumer price inflation, while aiming to ensure adequate holdings of foreign exchange reserves. Gross reserve coverage declined less than progranmed in 2001, and remains at a relatively comfortable 4.8 months of 2002 non-oil imports. The staff agreed with the authorities that a further decline in reserve coverage

20 The importance of developing a medium-term strategy for the use of oil fund assets was made clear by a recent policy discussion. The authorities raised the possibility of using oil fund assets to pay for SOCAR's share of BTC equity investments in 2002-04 (an estimated US\$170 million). The staff, while acknowledging the importance of ensuring financing for BTC, argued that the government should not be investing in commercial activities. In addition, diversion of oil fund assets to finance oil sector investments would undermine its stated purpose of entancing the development of the non-energy sectors of the economy. The authorities eventually concurred with the staff on this issue, and are working with the staff to find an alternative way for SOCAR to finance its share of BTC. 
in 2002 would be appropriate, but in light of the continuing uncertainties in the country's medium- to long-term balance of payments prospects, any such decline should be modest. Therefore, agreement was reached on a target of increasing gross reserves by US\$24 million, leading to a projected 4.5 months' reserve coverage at end-2002. Combined with the inflation target and real GDP projection for 2002, as well as the shared belief that velocity of manat broad money is likely to be broadly unchanged in 2002 , this will leave room for a modest expansion of credit, as credit to the economy will grow by slightly more than nominal GDP.

45. In light of the fairly steady rate of depreciation of the manat in recent years, the staff engaged the authorities in a discussion and review of the nature of exchange rate policy, seeking to determine whether the ANB was in fact following a policy of a managed floating exchange rate, or whether they were implementing an unannounced crawling peg policy. The authorities explained that they intervene in the foreign exchange market to offset temporary exchange rate pressures, but do not persistently intervene on one side of the market to offset more fundamental pressures. This was confirmed by a review of the ANB's interventions in the last two years, which show repeated interventions on both sides of the market, but no sustained intervention on either side. In light of this evidence that the market is in fact determining the exchange rate, and the earlier-noted modest rate of real depreciation in 2001 , it is the staff's assessment that the level of the nominal exchange rate is broadly appropriate at this time. There is no indication that competitiveness in the non-energy sector has been adversely affected by the exchange rate policy. However, there is a need to consider how exchange rate policy should evolve in the coming years, as both expenditures from the oil fund and total oil sector revenues are expected to increase substantially. The authorities reiterated their intention to accept the obligations of Article VII, sections 2, 3, and 4, and are working with the staff on revised procedures for issuance of tax clearance certificates (the one potential restriction identified by Legal and MAE in their review of Azerbaijan's exchange rate policies).

46. While progress continues on banking sector reforms (LOI, paragraphs 5 and 6), there has been a lack of progress in efforts to privatize the remaining shares of International Bank (IBA). The staff noted that it would be impossible to develop a truly competitive banking system in Azerbaijan while the government has a stake in this dominant bank. Progress on rehabilitating United Universal Bank (the other state-owned bank), however, has been more encouraging, with the Ministry of Finance finally completing the recapitalization of the bank, strict controls placed on the bank by the ANB pending further strengthening of the bank's capacity, and international consultants recently hired to assist in this process. The authorities agreed that adoption of timetables for full privatization of IBA and preparation for privatization of United Universal Bank, in consultation with the staffs of the Fund and World Bank, should be a structural performance criterion for end-March 2002.

47. The ANB expressed concern over the level of dollarization of the Azeri economy and noted its intention to address this problem. Effective December 18,2001, the ANB has begun requiring that all payments made in Azerbaijan be in manats. One additional measure they are considering is to introduce restrictions on the importation of foreign currency. The staff noted that this would not be an appropriate economic policy, and would lead to divergent 
cash and non-cash exchange rates. The staff explained that many countries have struggled to reverse dollarization, to little effect. It was agreed the staff would prepare a review of the experiences of other countries that have combated dollarization, on the basis of which we would seek to reach understandings on appropriate policy responses.

\section{Azerbaijan has taken tough measures to eliminate funding sources for} international crime, including terrorism, and to prevent money laundering. These measures include two presidential decrees in implementation of UN resolutions 1073 and 1373 , and instructions by the ANB to commercial banks to strengthen control on account transactions and to report any suspicious transactions. The ANB has provided banks with a list of suspected terrorists and criminal organizations, and has instructed them to put under strict supervision all transactions that could be initiated by any of the listed. The ANB has also distributed a summary of the "Wolfsberg Principles" to prevent money laundering and recommended that banks incorporate these principles in their internal procedures.

\section{Energy Sector Financial Discipline}

49. The staff and authorities held extensive discussions, over several missions and in conjunction with the staffs of the World Bank and EBRD, on the nature of a reform program to enhance financial discipline in the energy sector. ${ }^{20}$ While this program was to be adopted by end-September 2001 (a structural benchmark), delays in initiating its preparation, and the complicated nature of any truly comprehensive program, resulted in the program finally being adopted only in January 2002.

50. The program (LOI, paragraph 11) is comprehensive and ambitious, and is supported by both the staffs of the Fund and the World Bank. It includes measures to enhance payments by budgetary organizations, state-ownec enterprises and households; improve the efficiency of the utility companies as well as the larger energy-consuming stateowned enterprises; accelerate privatization in the sector; unify domestic and world market energy prices; and review, and adjust as necessary, utility tariffs. Important components of this reform program have already been adopted (LOI, paragraph 12), and development of a timetable for unifying domestic and world market prices (export prices in the case of oil, and import prices in the case of natural gas) for energy products is a proposed structural benchmark for end-March 2002. However, both the authorities and the staff recognize that this must be a long-term effort: improving efficiency, combating the culture of non-payment prevailing in the sector, and eventually eliminating subsidies worth one quarter of GDP cannot be done in months, but only in years. Nonetheless, the time-bound action plan the authorities have adopted is designed to produce significant results already in 2002.

\footnotetext{
${ }^{20}$ The staff estimates the quasi-fiscal subsidies in the energy sector, at world market prices, at roughly equal to 25 percent of GDP in 2000 (the last year for which full data are available).
} 


\section{E. External Sector Policies}

51. Azerbaijan continues to have a generally liberal trade policy, and the government has reiterated its commitment to further liberalize trade. Consistent with their commitments in the original MEFP, the government has committed to adopt by end-March 2002 a timetable for the gradual reduction of the number of specific import tariffs, as well as the weighted average tariff (a proposed structural performance criterion). In addition, in an effort to accelerate the process of WTO accession, the authorities have arranged for a WTO accession advisor to the Minister of Economic Development. Third, during 2002, subject to improvements in administrative capacity at the Customs Committee, the government will contemplate repiacing the ban on scrap metal exports with an export licensing scheme (LOI, paragraph 10).

\section{F. Poverty Reduction Strategy Paper}

\section{The authorities are making satisfactory progress in the preparation of a Poverty} Reduction Strategy Paper (PRSP), building on the interim version submitted to Fund and World Bank managements in June 2001. Sixteen sectoral working groups, including representation from government, parliament and NGOs, have been established and have prepared draft sectoral policy notes. On the basis of these notes, the government intends to organize a series of public discussions prior to the preparation of a full draft of the PRSP. The full PRSP will then be the subject of a national seminar. The government aims to complete the PRSP by July 2002. The staff believes there may be a need to extend this timetable somewhat, in order to ensure an effective participatory process.

\section{BaLance of Payments and Capacity to RePay}

53. The medium-term balance of payments projections assumes the most recent WEO projections for oil prices, as noted above, and full development of the BTC, ACG and Shah Deniz projects. The current account deficit is expected to increase from 23 percent of GDP in 2002 to an average of 31 percent in 2003-2004 before declining to 18 percent in 2005, with these deficits largely financed by foreign investment in the oil sector. The financing gap for the period 2004-2005 is projected to average about $\$ 98$ million per year. However, these projections depend critically on oil price assumptions (an increase of US\$1 per barrel, for a year, would reduce the projected financing gap for that year by about US\$36 million) and developments with regard to the major oil and gas sector projects.

54. Azerbaijan's external financing needs in 2002 (Table 8) will be covered by the proposed disbursements from the Fund (US\$42 million) and World Bank (US\$30 million in baiance of payments financing), as well as bilateral support, including from Gernany and the United States (following the suspension of the probibition of U.S. financial support to the government of Azerbaijan). In 2003, anticipated disbursements from the Fund and World Bank, as well as bilateral donots, are also expected to close the financing gap. Residual projected financing gaps in 2004 and 2005 will need to be addressed in the future.

55. Azerbaijan has had no difficulties in repaying the Fund, and the staff expects that to continue to be the case (Table 9). With the exception of the dispute with Uzbekistan, 
Azerbaijan has a good record of honoring its external obligations. ${ }^{22}$ Its external debt ratio is moderate (at about 22 percent of GDP in 2001) and its debt service obligations are around 5 percent of exports of goods and services. Obligations to the Fund are projected to peak in 2003, at less than 4 percent of exports of goods and services, or 10 percent of gross reserves.

\section{Program Monitoring}

56. Measures to be implemented prior to the completion of the review, as well as the structural performance criteria and benchmarks for end-March 2002, are listed in Table 10 and described in the LOI. Quantitative performance criteria for end-March and endSeptember 2002, as well as indicative targets for end-June and end-December 2002, are specified in the LOI, Table $1 .^{23}$ The updated disbursement schedule is presented in Table 11.

57. As noted above, three end-September 2001 structural performance criteria and one structural benchmark were missed, in part due to delays by the authorities. These delays can largely be attributed to coordination problems - the failure of anyone in the government to monitor commitments, and progress toward their implementation, on a timely basis. To prevent a recurrence of such problems, the anthorlties have adopted procedures for the monitoring of reforms and program commitments (LOI, paragraph 13).

\section{Technical assistance Consultations}

\section{Technical Consultation discussions indicated that technical assistance (TA)} provided by the Fund has generally been well received and successfully implemented. An assessment of recent technical assistance from the Fund and future TA needs was discussed with the authorities and modified in the view of the authorities' comments (Appendix V). The authorities were especially appreciative of the work done by resident advisors on the creation of a single treasury account and the development of a Government Financial Management Information System for the treasury, on tax administration, and on banking supervision and restructuring. The intensive technical assistance that helped in the introduction of a Real Time Gross Settlements System for high value payments in early 2001 was also much appreciated.

59. Looking forward, the authorities stressed the need for continued technical assistance to develop the government's capacity in the fiscal and monetary areas. In the fiscal area, support was requested to further develop the treasury's Government Financial Management Information System and to strengthen the auditing capacity of the Ministry of Taxes. In the monetary field, the authorities requested TA to develop the new Banking Systems Law, and an

\footnotetext{
${ }^{22}$ The outstanding debt to Turkmenistan remains in dispute despite the Azeri authorities' efforts to reach a resolution. As a result, there is still no agreement on the principal, a repayment schedule or interest obligations with regard to this debt.
}

${ }^{23}$ As explained in the LOI, net credit to government will be measured excluding any unspent funds that have been transferred to the treasury from the oil fund. 
action plan to improve competition in the banking sector, and to help develop the small payments system. The authorities also requested further technical assistance in strengthening macroeconomic statistics, including a resident national accounts statistics advisor. A mission that will assess the quality of all macroeconomic statistics is scheduled for April 2002.

\section{STAFF APpraISAL}

60. Program implementation to date has been strong, notwithstanding delays that led to the need for several waivers. Financial policies continue to be consistent with macroeconomic stability, and the authorities have adapted well to the changing international environment. The accelerated pace of structural reforms, which began well before the approval of the PRGF amangement, continues. The continuation of macroeconomic stability, structural reforms and enhanced governance should stimulate growth and job creation in the non-oil sectors of the economy in the coming months and years, and thereby contribute to the government's poverty reduction goals.

61. The staff believes the authorities' fiseal stance remains appropriate in light of the macroeconomic prospects for the country. However, there will be a need to carefully monitor revenue developments, and to be prepared to adjust the budget if developmentsparticularly those related to the oil sector-should turn out less positive than currently expected. The staff urges the authorities to strengthen revenue forecasts and the operations of the treasury bill market, which should both contribute to improved expenditure management and avoidance in the future of pension or other arrears. In addition, it will be important for the authorities to strengthen efforts to develop a solid MTEF and PIP, both to support the preparation of a meaningful PRSP and to ensure oil fund revenues are used to support the government's poverty reduction strategy.

62. The most crucial part of the government's reform plan is the program to enhance financial discipline in the energy sector. Given the size of the quasi-fiscal subsidies in the sector, it will be impossible to enhance the efficiency of the economy, and accelerate job creation in a sustainable fashion, without substantially enhancing payments discipline. In that context, the staff welcomes both the comprehensive program the government has adopted and the significant initial steps already taken. Acknowledgement of the subsidies being provided to Azerenergy and Azerigas, and their inclusion in the reports on budget execution - this action will increase teported revenues and expenditures each by more than 20 percent-is a bold and important move, which should help create support for other elements of this reform program. In addition, the authorities' planned public awareness program will also help develop this necessary support.

63. The staff believes now is the time to develop a careful, and detalled, plan for incorporating the oil fund into the government's overall medium-term development strategy. The staff welcomes the progress made in 2001 on the asset management and investment rules, as well as on the careful integration of the planning, execution and monitoring of the oil fund and state budgets in the context of a truly consolidated budget. However, the recent debate over the possible use of oil fund assets to finance commercial pipeline developments emphasizes the risks of baving a pool of funds available, without clear 
guidelines regarding the legitimate use of those funds - both in terms of what they can be spent on and of the tining of any such expenditures. The staff urges the authorities to develop such guidelines during the course of 2002, in consultation with the Fund and World Bank.

\section{The staff is encouraged by the reforms in the banking sector, but is concerned} about the lack of progress in privatizing the remaining state-owned banks. While good progress is being made in rehabilitating United Universal Bank-with technical and financial assistance from the World Bank-there remains much to do before the bank will be able to operate as an effective commercial bank. It will be important for the management of United Universal to make effective use of the international advisors being provided to them. Now that the bank has received its final capital injection, the staff urges the ANB to ensure that prudential requirements are enforced on United Universal, just like any other bank. The process of privatizing of IBA appears to have come to a temporary halt, for reasons that are unclear. The staff urges the authorities to move quickly to sell the remaining government stake in IBA to fit and proper investors. Without such a step, it will be impossible to create a competitive banking system that can support the development of a diverse economy.

65. The staff believes the exchange rate of the manat is appropriate, as is the exchange rate policy being followed by the ANB. The on-site safeguard assessment report is being prepared as required under the Safeguards Policy, but since staff has not yet obtained the authorities' formal comments on the report, the assessment will not be completed by the time of the Executive Board's consideration of the first program review. Nevertheless, the staff proposes to compiete the review, given the limited risks of misuse and misreporting identified during the on-site assessment and the authorities' commitment to addressing the identified weaknesses. Staff expects that the assessment will be completed by early March.

66. The staff is satisfied that the existing economic statistics provide a satisfactory basis for analyzing economic developments in Azerbaijan. Nonetheless, there is a need to strengthen the statistical system, and the staff urges the authorities to continue their efforts in this regard, in cooperation with the staff of the Fund.

\section{The staff is encouraged by the progress on improving governance in 2001 and} urges the authorities to accelerate that progress in 2002. The staffing, funding and expansion of the authority of the Chamber of Accounts (the supreme audit institution, reporting to parliament); passage of an improved procurement law; commitment to public reporting and auditing of the activities of the oil fund; and improvements in tax administration have contributed to enhancing governance in Azerbaijan. In 2002, it will be important to build on those efforts, and to extend the efforts to improving governance in the Customs Committee, in the context of the recently approved reform program. It will also be important to adhere to the rules regarding oil fund expenditures.

68. The risks to program implementation are largely the same as noted at the time the program was originally approved, although the staff believes those risks have been somewhat reduced. First, while there remain risks related to the major energy sector projects, progress in recent months significantly reduces those risks. Also, the fact that the program is now built on much lower oil price projections reduces the risk related to possible future 
movements in oil prices. Second, while the concem about the ability of the government to make decisions and implement reforms in a timely fashion has been proven justified by events, the staff is hopeful that the new procedures for monitoring the implementation of program commitments will reduce this risk in the future.

69. Overall, the staff continues to believe the program bas good prospects for success. The authorities are requesting waivers of one continuous and three structural performance criteria; the staff supports these requests, since all policies subject to performance criteria have been implemented and the delays did not jeopardize achievement of the program's objectives. Given the authorities' strong track record in implementing sound financial policies, the impressive track record of structural reforms in the last two years, and the solid performance to date under the PRGF arrangement, the staff recommends completion of the first review under the PRGF arrangement.

70. The staff proposes that Azerbaijan remain on an annual Article IV consultation cycle. 
$-26-$

Table 1. Azertajian: Selected Economic and Financial Indicators, 2000-2005

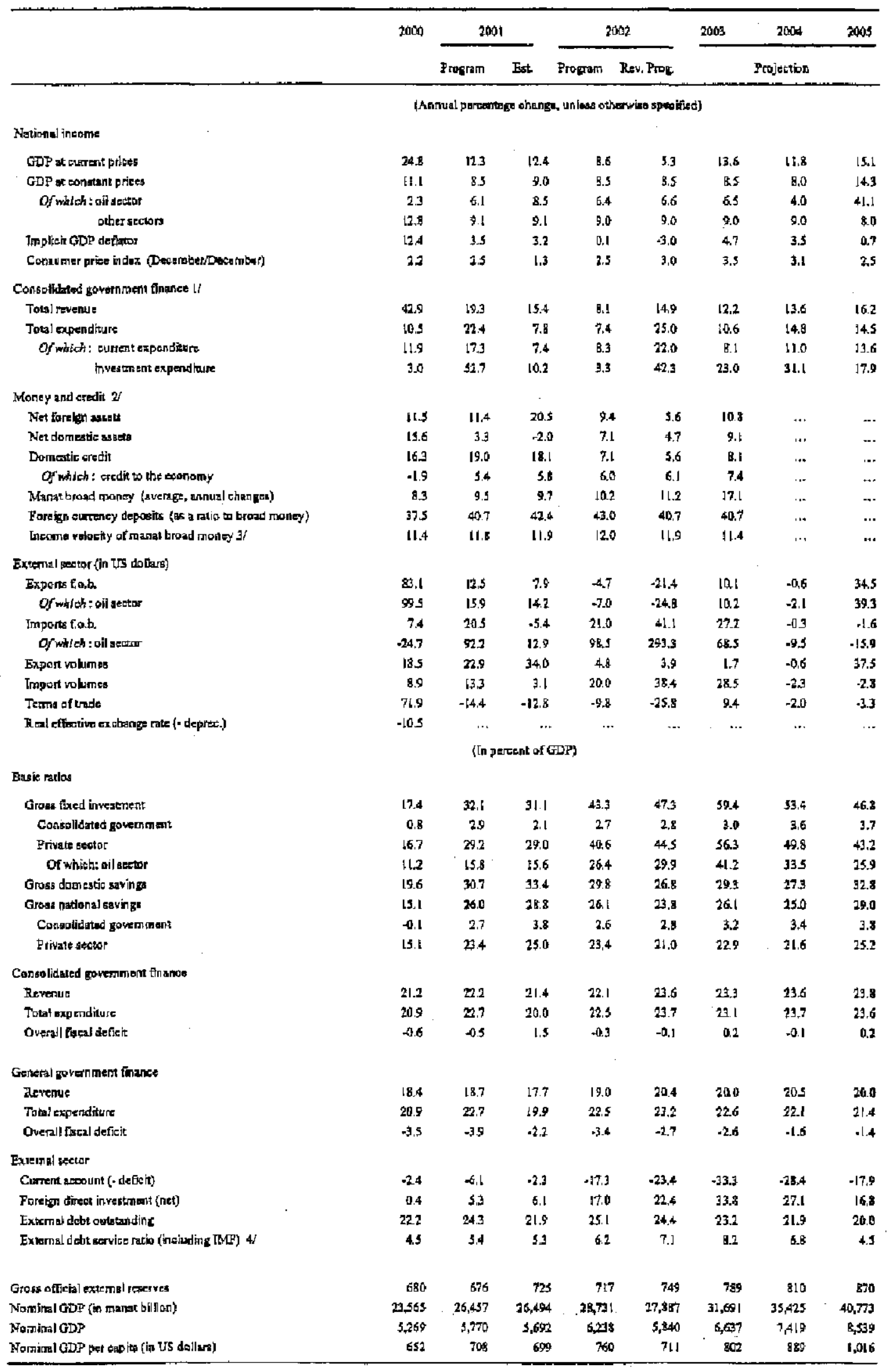

Sourcer: Azeri guthoritifes and staft estimates and projertions

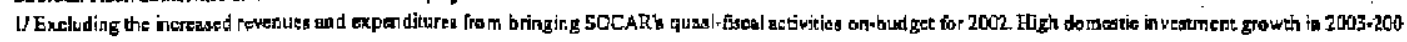
lasgely reflects projected investnerts trom Oll Fupd resources

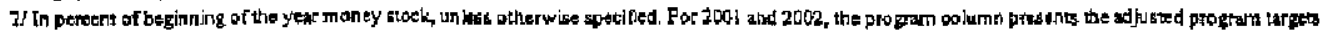

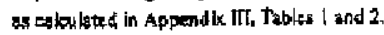

$3 /$ Th $\operatorname{cerm}$ of nomal! GDP.

$4 /$ In pereent of exports of goods and services. 
Table 2. Azertaijan: Quantitative Perfonnance Criteria and Renchmarks for the PRGF, April 1 2001- Dexember 31, 2002

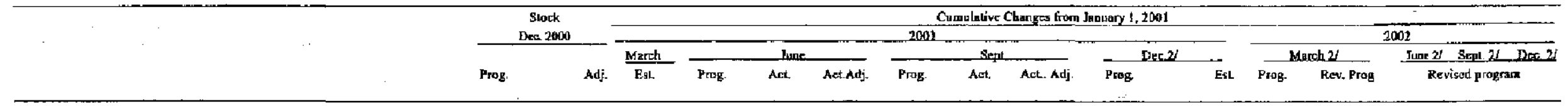

(In billions of manzas, unless olkerwise sperificil)

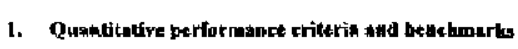

Ne1 international reserves of the ANB pis UAS mittion)

Net domestic assets of the ANB

Nel eredn to the Eenefal goreniment fram the ANB if

Overall consolitated fiscai deficit, enchuding Oil fund nevenues

New Nosconcessional External Debt Contracted or Guarantited by the

Cansolitinated Gavernmemt or the ANH (exeluding the IMF)

Less than ont ridr's matsrity

Medium-and foggteron debt, less than five year

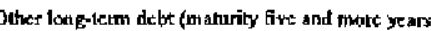

2. Coutinurous perfinmance trilerion

Stock of Oulstanting Nonresctedulable Extemal Anctars of the

Consolidatad Government and the ANB

\section{Indidcative bargets}

Stoek or ANB's manat reserve money

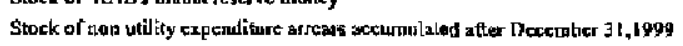

\begin{tabular}{|c|c|c|c|c|c|c|c|c|c|c|c|c|c|c|}
\hline $3 / 4$ & .15 & 1 & 5 & 4 & 1 & 93 & 91 & 25 & BS & 30 & 81 & 100 & 108 & 115 \\
\hline 199 & -251 & -106 & -291 & -288 & -63 & $-60 !$ & -593 & -69 & -379 & -58 & 41 & -356 & -348 & -332 \\
\hline-90 & -69 & -17 & -42 & -39 & 0 & -237 & -229 & -19 & -72 & -19 & -147 & -75 & 92 & -100 \\
\hline-821 & -221 & -430 & -359 & -436 & 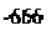 & -722 & -397 & $-1,027$ & -592 & $-1,247$ & -797 & $-1,095$ & $-1,301$ & \\
\hline
\end{tabular}

$-2$

0

...

$\begin{array}{rrr}0 & 0 & 0 \\ 0 & 0 & 0 \\ 0 & 40 & 0\end{array}$

n

$1,542 \quad 1,542$

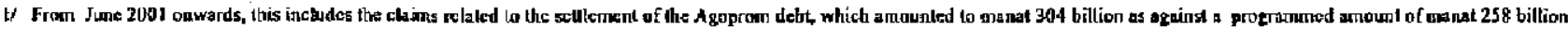

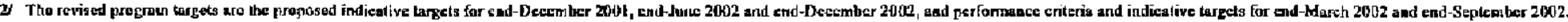


Table 3. Azcribaijan: Monctary Survey, 2000-2003 1/2/

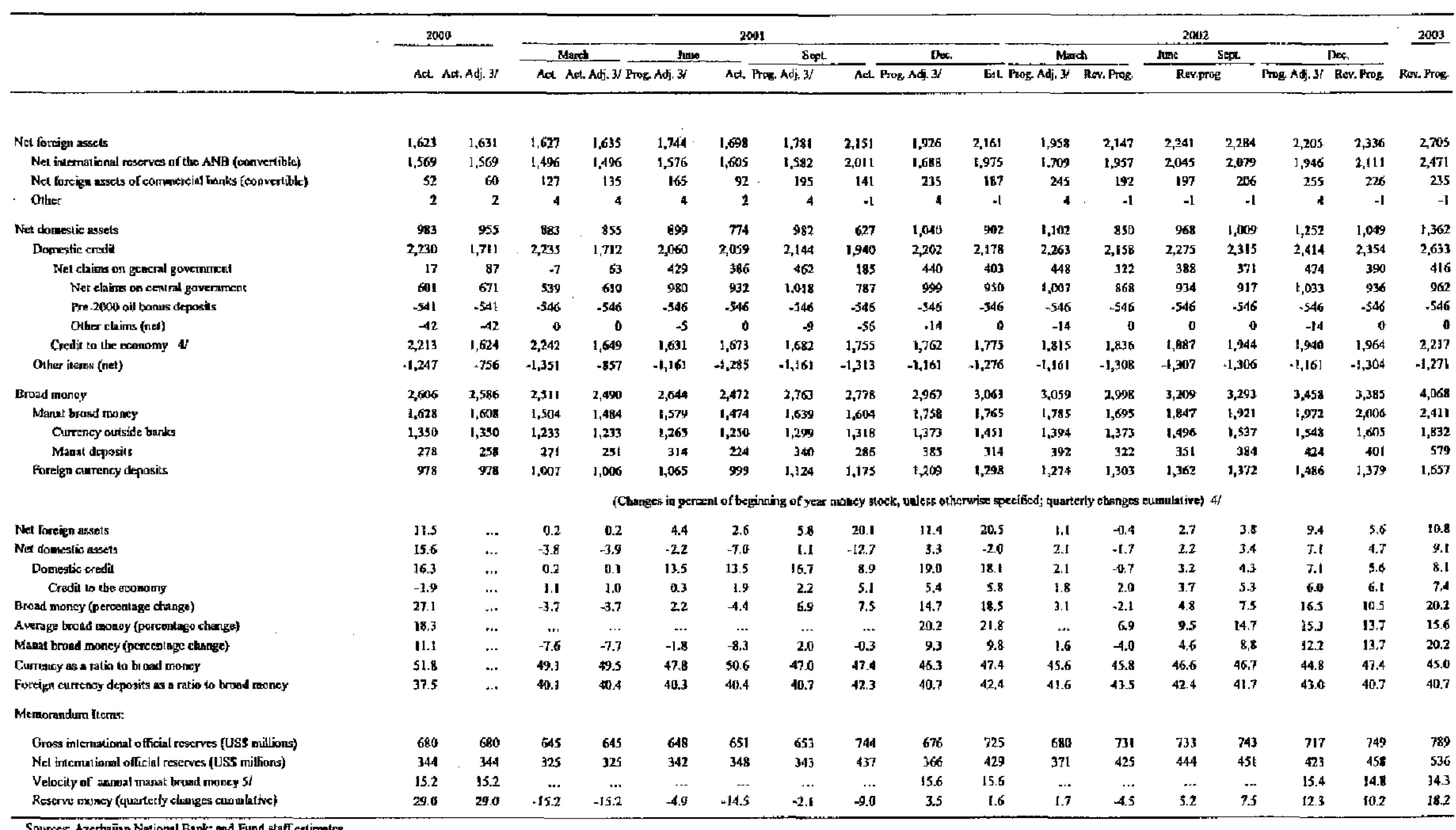

\section{Sources: Azerbaīan National Eank; and Fund otaff estimates.}

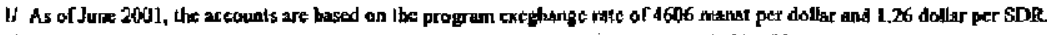

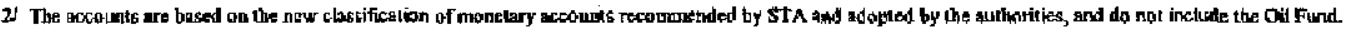

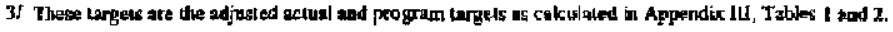

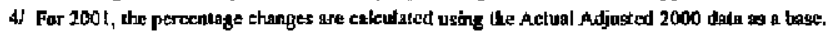

St Velocity in derined a noninal GDP divided by average broad money. 
Table 4. Azerbaijan: Surnmaty Accounts of the Azerbaijan National Bank, 2000-2003 I/ $2 /$ (In billions of manats)

\begin{tabular}{|c|c|c|c|c|c|c|c|c|c|c|c|c|c|c|c|c|c|}
\hline \multirow{4}{*}{ Thet interantional restrves (carremibte) } & \multicolumn{2}{|c|}{2000} & \multicolumn{8}{|c|}{2001} & \multicolumn{6}{|c|}{2002} & \multirow{4}{*}{$\frac{\frac{2003}{\text { Rsv. howg }}}{2,471}$} \\
\hline & \multirow{3}{*}{$\begin{array}{c}\text { Atet } \\
1,569\end{array}$} & \multirow{3}{*}{$\frac{\text { Act Adij- }}{1,569)}$} & \multicolumn{2}{|c|}{ Manst } & \multirow{2}{*}{ henc Al. } & \multirow{2}{*}{\multicolumn{2}{|c|}{ 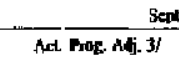 }} & \multirow{2}{*}{\multicolumn{2}{|c|}{ Adt Prog Adjar }} & \multirow[b]{2}{*}{ Est } & \multicolumn{2}{|c|}{ Morch } & \multirow{2}{*}{\multicolumn{2}{|c|}{ 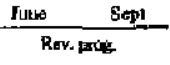 }} & \multicolumn{2}{|c|}{$-\frac{\mathbf{D}_{x_{2}}}{-}$} & \\
\hline & & & Aat & Ast Acti. 1 & & & & & & & Prag Adj 3 & Rev. Prog & & & Prest Af 3 & Pere, Proge. & \\
\hline & & & 1.996 & $1,4 \%$ & 1,576 & 1,605 & 1,582 & $2,01 \mathrm{t}$ & $1,6 \$$ & 1,975 & 1,710 & 1,957 & 2,045 & 3079 & 1,946 & 2,111 & \\
\hline Gross internationdid nesorvss (cortuertible) & 3,102 & 3,102 & 2,970 & $29 \% 0$ & 2983 & 2,999 & 3,009 & 3,426 & 3.112 & 3,339 & 3,132 & 3,365 & 3,374 & 3,474 & 3,302 & 3,452 & 3,536 \\
\hline 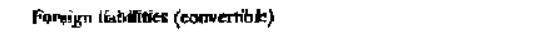 & $-1, \$, \$ 4$ & $-1,534$ & $-1,474$ & $+1,474$ & $.1,406$ & $-1,555$ & $-1,427$ & $-1,415$ & $-1,425$ & $-1,36 d$ & $-1,422$ & $-t, 408$ & $\cdot 1,329$ & $-1,346$ & $-4,735$ & $-1,340$ & $-1,165$ \\
\hline Net domestc assets & 199 & 199 & -52 & 57 & 105 & -93 & 147 & 100 & 192 & Itso & 192 & -242 & $-\$ 57$ & -149 & 107 & -133 & -133 \\
\hline Domestic eredit & 612 & $\mathbf{6 1 2}$ & 158 & 458 & $\$ 61$ & 3 300 & 601 & 64 & 597 & 243 & 608 & 180 & 263 & 269 & $\$ 63$ & 285 & 273 \\
\hline 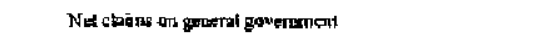 & 90 & -90 & .159 & -159 & 199 & 172 & 315 & .22 & 198 & 142 & 195 & 67 & 134 & 122 & 129 & 106 & 81 \\
\hline Net chiarns on cratral government & $\$ 52$ & 452 & $36 \mathrm{~T}$ & 387 & 744 & 719 & 761 & 524 & 741 & 6AB & 741 & 613 & 685 & 669 & 675 & 652 & 628 \\
\hline Pte -2000 oil harius deposits & -541 & $-5+1$ & .546 & .546 & -546 & -546 & .546 & -546 & -546 & $-5 * 6$ & -546 & -546 & -546 & -546 & .546 & $-\$ 46$ & -546 \\
\hline Clains on banks & 701 & 701 & 617 & 617 & 363 & 197 & 388 & 86 & 102 & 101 & 413 & 113 & 123 & E4 & 434 & 179 & 191 \\
\hline Other inenis (net) & +13 & $\$ 13$ & .511 & -511 & -456 & 462 & -566 & -466 & -156 & -423 & -956 & -122 & $-4 \neq 0$ & פום- & $-456^{\circ}$ & -418 & -406 \\
\hline Resiwe maney & 1,764 & 1,767 & 1,499 & 1,499 & 1,681 & $1,5: 2$ & 1,730 & 1,609 & 1,825 & 1,795 & $1,86 \mathrm{t}$ & 1,714 & 1,888 & 1,930 & 2,054 & 1,078 & 2,338 \\
\hline 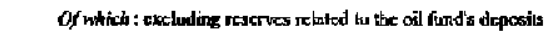 & $t, 642$ & 1,642 & 1,499 & 1,499 & $1,68 \mathrm{II}$ & 1,512 & 1,730 & 1,609 & 1,826 & 1,795 & 1,857 & 1,314 & $\mathbf{1 , 8 8 8}$ & $t, 930$ & 2,050 & $1,9 \pi$ & 2,338 \\
\hline Matal tesenve numey & 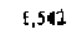 & 1,542 & 1.431 & $1,43 t$ & 1,561 & 1,422 & 1,603 & 1,505 & 1,695 & 1,681 & 1,720 & 1,623 & 1,774 & 1,82I & $\mathrm{t}, \mathbf{8 9 2}$ & 1,855 & 2,211 \\
\hline Cantenty in cisculming & 1,420 & 1,420 & 1,314 & 1.314 & 1,348 & $\mathrm{t}, \mathbf{3 1 \mathrm { R }}$ & 1,366 & 1,396 & 1,444 & 1.534 & 1,466 & 1,442 & 1,572 & 1,615 & 1,62: & 1,697 & 1,497 \\
\hline Bank reserves & 122 & 122 & 117 & 117 & 213 & 105 & 237 & 109 & 151 & 147 & 254 & 183 & 202 & 2017 & 263 & 158 & 314 \\
\hline Reserves in fortigu curenciss & 223 & 223 & 65 & 65 & 116 & 87 & 122 & 99 & 130 & $10 T$ & 137 & 82 & 197 & 101 & $15 k$ & I16 & 120 \\
\hline Olher depasits & 2 & 2 & 4 & 4 & 4 & 3 & 4 & 9 & 4 & 7 & 4 & 7 & 7 & 7 & 4 & 1 & 7 \\
\hline
\end{tabular}

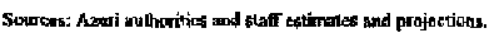

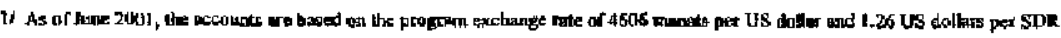

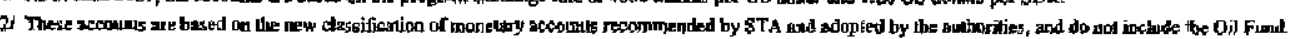

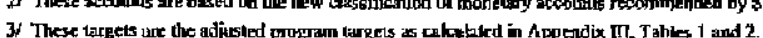


Table 5. Azabaijar : Consolidated Government Operations, 2001-2003 (In billions of manats)

\begin{tabular}{|c|c|c|c|c|c|c|c|c|c|c|c|c|}
\hline & \multicolumn{3}{|c|}{2001} & \multicolumn{7}{|c|}{2002} & \multicolumn{2}{|c|}{3003} \\
\hline & \multicolumn{2}{|c|}{ Budgo Program } & \multirow[t]{2}{*}{ Proj. } & \multirow[t]{2}{*}{ QI } & \multirow{2}{*}{\multicolumn{2}{|c|}{$\frac{\mathrm{Q}^{2}}{\text { Roviand Progem }}$}} & \multirow[t]{2}{*}{ Q4 } & \multicolumn{3}{|c|}{ Yaser } & \multirow{2}{*}{\multicolumn{2}{|c|}{ PIogam Rex.Prog 2/ }} \\
\hline & & & & & & & & Progran & Fudgat & Rev, Prop $\mathbf{z}$ & & \\
\hline Total reverille and grants & 3,954 & 3,886 & 9,678 & 1,439 & $1,54 B$ & 1,626 & 1,967 & 6,367 & 6,538 & 6,580 & 6,942 & 7,370 \\
\hline Totol reveative & 5,910 & 5,842 & 5,650 & 1,435 & 1,548 & 1,625 & 1,873 & 0,314 & 6,491 & 6,491 & 6,892 & 7,281 \\
\hline Tax tevente & 3,969 & 3,502 & 3,916 & 3,043 & $1,3,4$ & $1,20.5$ & 1,264 & 4,372 & 4,648 & 4,648 & 4,997 & 5,179 \\
\hline hiome tax & 1,106 & 1,091 & 1,06 & 283 & 201 & $\$ 20$ & 126 & 1,289 & 1,230 & 1,230 & 1,566 & 1,455 \\
\hline Individual intoms $\mathbf{c x}$ & 640 & 515 & 445 & .722 & 230 & 138 & $i \Delta d$ & 613 & 530 & 530 & 744 & 978 \\
\hline 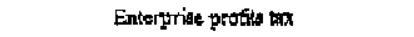 & 566 & 576 & 696 & 161 & 172 & 182 & 186 & 674 & $70 \mathrm{n}$ & 700 & 822 & 87 \\
\hline Of which : ail sector & $\ldots$ & 513 & 267 & $\ldots$ & $\ldots$ & $\ldots$ & $\ldots$ & $\mathbf{W 7}$ & $\cdots$ & 260 & 307 & 375 \\
\hline Social socurity cothrbutions & 587 & 587 & 582 & 14 & 147 & 175 & 178 & 617 & 643 & sa3 & 699 & T16 \\
\hline Velus dded ux [VAT] & $1, \mathbf{0 0 8}$ & 1,183 & 1,275 & 373 & $\$ 19$ & 408 & 436 & 1,315 & 1,635 & i, E35 & 1,517 & $1,8,5,4$ \\
\hline Of which: on petroleum products & $\ldots$ & 328 & 429 & $\ldots$ & $\ldots$ & ... & $\ldots$ & 321 & $\cdots$ & 540 & 321 & 615 \\
\hline Exsine taxen & 530 & 272 & 379 & $1+3$ & 122 & 138 & 133 & 300 & 495 & 495 & 135 & 543 \\
\hline Texes op imierrationsl trade & $45:$ & 589 & 475 & tog & .22 & 124 & 138 & $6+7$ & 492 & 492 & 672 & 471 \\
\hline Other iaxex & 120 & 180 & 198 & 22 & 24 & 5 & 31 & 195 & 153 & 293 & 208 & 174 \\
\hline Nonlax revenue & $1,94 \mathbf{1}$ & 1,940 & 5,740 & 396 & 114 & 420 & 613 & 1,942 & 1,843 & 1,843 & 1.894 & 2,102 \\
\hline Of which: Oil Fund revenues $H$ & 977 & 897 & 917 & 215 & 118 & 209 & 237 & 869 & 880 & 880 & 811 & 1,025 \\
\hline expubudgetary & 215 & 227 & 215 & 49 & 54 & 59 & 73 & 246 & 2015 & 235 & 253 & 367 \\
\hline Total grates f(Gurent) & 44 & 44 & 28 & 0 & 0 & 0 & 89 & 48 & 47 & BS & 51 & 89 \\
\hline Total expenditure & E, 156 & 6,016 & 5,296 & 1,420 & 1,628 & 1,520 & 1,940 & 0,460 & 6,557 & 5,610 & 7,126 & 7,323 \\
\hline Curtent expenditure & 4,921 & 4,927 & 4,510 & 1.173 & 1.333 & 1,328 & 1,067 & 5,333 & 3,458 & 5,501 & 5,859 & 5,947 \\
\hline 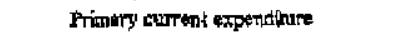 & 4,799 & 4,805 & 4,390 & 1,140 & 1,304 & 1,306 & 1,630 & 5,224 & $5,3 * 3$ & 5,386 & 5,748 & 5,815 \\
\hline Wogea and salarieg & 1,31 & $1,3: 1$ & 1,148 & $3: 8$ & 415 & 336 & 430 & 9,414 & $1,50 x$ & 1,502 & 1,5399 & 1,598 \\
\hline coods and services & 1,365 & 1,345 & 1,206 & 304 & 368 & 338 & 427 & 1,522 & $1,4,5$ & 1,435 & 1,689 & 1,616 \\
\hline Transfers to households & 1,699 & 1,700 & 9,671 & 458 & 437 & 516 & 593 & 1,872 & 1,973 & 1,979 & 2,064 & $2,1,72$ \\
\hline Of libitah: ancialprotedion & 1,350 & 1,350 & 1,550 & 339 & 942 & 371 & 104 & 1,506 & $1,45 ?$ & 1,457 & 1,668 & 1,592 \\
\hline Subaidiea & 110 & 110 & 110 & 16 & 16 & 40 & 84 & IE & 3]4 & 156 & $\mathbf{a z}$ & 124 \\
\hline Ol Fond (aperating expendimses) & 0 & 0 & 0 & $\mathbf{I}$ & l & 1 & 2 & 0 & 3 & 3 & 0 & 3 \\
\hline Other & 313 & 319 & 256 & 4) & 65 & 76 & 135 & 328 & 317 & 317 & 347 & 353 \\
\hline Or which : extrebudgetery & 205 & 237 & 205 & 37 & 61 & 54 & 73 & 246 & 235 & 233 & 263 & 267 \\
\hline Interest & 122 & 128 & 120 & 27 & 29 & 23 & 36 & III & 115 & 115 & ill & I3I \\
\hline domestic & 31 & 31 & 25 & 10 & 6 & 6 & $E$ & 27 & 29 & 29 & 32 & $3 \%$ \\
\hline extertial & 91 & $\$ 1$ & 9 & ד & 23 & 16 & 30 & 84 & 36 & 85 & 79 & 54 \\
\hline Current babnes (defisitr-) - & 1,033 & $9 \leq 9$ & 1,168 & 366 & 215 & 299 & 390 & 1,027 & 1,080 & 1,080 & 1,084 & 1.474 \\
\hline Investment experiditurs and net lending & 1,235 & 1,089 & 780 & 256 & 295 & 295 & 273 & 1,125 & 1,119 & 1,119 & 1,268 & 1,376 \\
\hline Domestica By-thathued & 345 & 345 & 315 & 136 & 128 & 159 & 167 & 416 & $\$ 90$ & 590 & 523 & 758 \\
\hline Foreign-finaneed & 889 & 743 & 47] & 121 & 167 & 136 & 106 & 709 & 590 & 929 & 244 & 618 \\
\hline Stariatical diereprency & 0 & 0 & -3 & 0 & 0 & 0 & 0 & 0 & 0 & 0 & 0 & G \\
\hline Congabidated gavernonent dotioth, aseh basis & -200 & เ & 385 & 10 & .80 & 3 & 27 & -58 & 40 & .59 & .184 & 48 \\
\hline Exchuding Dil Fund (gerteral govermme ni) & $-1,179$ & $-1,027$ & -580 & -167 & -259 & .167 &.$|7|$ & 967 & .764 & .764 & -955 & -812 \\
\hline Exchuding forreign project loams & 687 & 613 & 865 & 131 & 87 & 139 & ] & $6: 1$ & 490 & 490 & 360 & 665 \\
\hline Finaneing & 202 & .130 & .585 & -10 & 79 & -4 & .27 & 98 & 40 & 39 & 184 & 0 \\
\hline Danssotic (bet) & -826 & .740 & 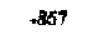 & .364 & .79 & .132 & .129 & -876 & -599 & .599 & 825 & .932 \\
\hline Banking 5yatem 3 & 53 & -4 & 52 & -8 & 66 & -17 & 19 & 13 & id & $\mathbf{3 3}$ & J6 & 26 \\
\hline or which-fressory bith & 50 & w. & 6 & 0 & -2 & 0 & 36 & $\ldots$ & 34 & 34 & .. & SD \\
\hline Oilfund & $-T_{2} \mathbb{8} \mathbf{6}$ & .920 & $-1,050$ & .176 & -179 & -171 & .198 & $-1,099$ & .725 & .725 & $-1,041$ & $-1,108$ \\
\hline Nonbank seetor & 10 & 10 & -64 & 5 & $s$ & 3 & 9 & 0 & 20 & 20 & 0 & 0 \\
\hline Privatizarions and ocher sale of assets & 200 & 200 & IDI & 20 & 30 & 50 & 59 & 210 & 150 & iso & 140 & 150 \\
\hline Other & 64 & -14 & 83 & 31 & 0 & 0 & 0 & 0 & -31 & -11 & 0 & 0 \\
\hline Extemel (net) & 7,028 & 870 & $4 \$ 1$ & 295 & 138 & 129 & 97 & 974 & 6.39 & 639 & 1,010 & 933 \\
\hline Loans & 1,071 & 913 & 514 & 281 & 173 & 153 & 112 & 1,090 & 720 & 730 & 3,075 & tioni \\
\hline Projecl loane & 888 & 742 & 489 & 137 & 173 & 153 & נונ & 710 & 576 & 576 & 745 & 619 \\
\hline Ou boruses & 23 & 32 & 23 & 0 & 0 & 0 & 0 & 230 & 0 & 0 & 230 & 239 \\
\hline Workd Bark SAC & 160 & i38 & 0 & 143 & 0 & 0 & 0 & 100 & {$[4]$} & $14]$ & 100 & 143 \\
\hline Amortization due & 43 & -43 & 3 & .25 & -15 & -24 & -15 & -56 & -80 & -80 & -66 & -68 \\
\hline Change in excemal strears & & & 1 & +1 & 0 & $\cdot 0$ & 0 & & 0 & -1 & & \\
\hline Frnameing gap & 0 & 0 & 0 & 0 & 0 & 0 & 0 & $\theta$ & 0 & 0 & 0 & 48 \\
\hline
\end{tabular}

Soutees: Ameri authorities and staft estimates and projections.

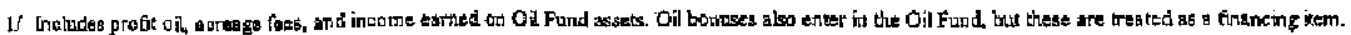

2f Exa hudes quati-fiscal energy seator revenues and expenditurec. Revenue and expenditure include 42 bilion manat from a gont by Germany which was bigned after the buedget tor 2002 was passed.

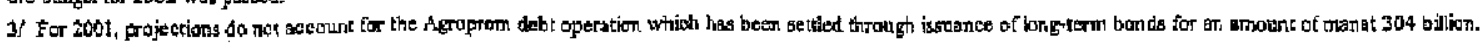
CInternational Monetary Fund. Not for Redistribution 
Table 6. Azerbaijan: Selected Fiscal Indicators, 2000-2003

(In percent of GDP, unless otherwise specified)

\begin{tabular}{|c|c|c|c|c|c|c|c|}
\hline & \multirow{2}{*}{$\begin{array}{l}2000 \\
\text { Act. 1/ }\end{array}$} & \multicolumn{2}{|c|}{2001} & \multicolumn{3}{|c|}{2002} & \multirow{2}{*}{$\frac{2003}{\text { Projection } 2 /}$} \\
\hline & & Program & Proj. & Program & Budget & & \\
\hline Total revenue and grants & 21.2 & 22.2 & 21.4 & 22.1 & 23.4 & 23.6 & 23.3 \\
\hline Total teremile & 20.8 & 22.1 & 21.3 & 22.0 & 23.3 & 23.3 & 23,0 \\
\hline Of which : tax revenue & 14.5 & 14.8 & 14.8 & 15.2 & 16.7 & 16.7 & 36.3 \\
\hline montax revenue & 6.3 & 7.3 & 6.6 & 6.8 & 6.6 & 6,6 & 6.6 \\
\hline Of which : oil revenue & 7.5 & 8.7 & 8.9 & 7.9 & 9.4 & 9,4 & 9.5 \\
\hline nonoil revenuse & 13.3 & 13.4 & $\$ 2.4$ & 14.1 & 13.9 & 13.9 & 13.5 \\
\hline Nonoil revenue (percent of nanoil GDP) & 17.7 & 17.8 & 26.3 & 18.2 & 17.2 & 17.2 & 17.0 \\
\hline Total grants (current) & 0,3 & 0,2 & 0.1 & 0.2 & 0.2 & 0.3 & 0.3 \\
\hline Total expenditure & 20.9 & 22.7 & 20.0 & 22.3 & 23.6 & 23.7 & 23.1 \\
\hline Primary expenditure & 20.5 & 22.3 & 19.5 & 22,1 & 23.2 & 23.3 & 22.7 \\
\hline Primary current expenditure & 17.4 & 182 & 16.6 & $18.2^{-}$ & 19.2 & 19.3 & 18.3 \\
\hline Of which : wage bill & 4.6 & 5.0 & 4.3 & 4.9 & 5.4 & 5.4 & 5.0 \\
\hline goods and services & 4.8 & 52 & 4.6 & 3.3 & 5.1 & 5.1 & 5.1 \\
\hline transfers & 67 & 6.4 & 6.3 & 6.5 & 7.1 & 7.1 & 6.7 \\
\hline Domestically financed investment and net lending & 1.3 & 1.3 & 1.2 & 1.4 & 2.1 & 2.1 & 2,4 \\
\hline Foreign-financed investment & 1.7 & 2.8 & 1.8 & 2.5 & 1.9 & 1.9 & 2.0 \\
\hline Interest on public debt & 0.4 & 0.5 & 0.5 & 0.4 & 0.4 & 0.4 & 0.4 \\
\hline Wages' primary expenditure (in percentage) & 26.5 & 27.3 & 26.1 & 27.1 & 28.1 & 27.9 & 27.5 \\
\hline Transfers / primary expenditure (in percentage) & 38.3 & 35.4 & 38.1 & 33.8 & 36.9 & 36.6 & 36.7 \\
\hline Wages' ron-oil revenue (in percentage) & 34.9 & 37.1 & 34.9 & 34.8 & 38.8 & 38.8 & 37,4 \\
\hline Transfers / nonoil revenue (in percentage) & 50.4 & $4 B .0$ & 50.8 & 46,1 & 50.9 & 50.9 & 49.9 \\
\hline Expenditure in eductation and bealth & 4.7 & 4.8 & 4.8 & 3.2 & 4.8 & 4.8 & 5.1 \\
\hline Education & 3.8 & 3.8 & 3.8 & 4.0 & 3.9 & 3.9 & 4.0 \\
\hline Health & 0.9 & 1.0 & 1.0 & 1.1 & 1.0 & 1.0 & 1.1 \\
\hline Military expenditure & 2.1 & 2.0 & 1.9 & 2.0 & 2.2 & 2.2 & 22 \\
\hline Current expenditure & 17.8 & 18.6 & 17,0 & 18.6 & 19.6. & 19.7 & 18.8 \\
\hline Investment expenditure & 3.0 & 4.1 & 3.0 & 3.9 & 4.0 & 4.0 & 4.3 \\
\hline Current balance ( $+=$ surphus $)$ & 3.4 & 3.6 & 4.4 & 3.6 & 3.9 & 3.9 & 4.5 \\
\hline Primary balance $(+=$ sutplus) & -0.3 & 0.0 & 1.9 & 0.0 & 0.3 & 0.3 & 0.6 \\
\hline Primary balarce, excluding oil ( + -surplus) & .7 .8 & -8.7 & -7.0 & -7.8 & $-9,1$ & -9.1 & -8.9 \\
\hline Primary balance (excl. externally firanced investment) & 1.4 & 2.8 & 3.7 & 2.5 & 2.2 & 2.2 & 2.5 \\
\hline Consalidared government deficit, cash basis & -0.6 & -0.5 & 1.5 & -0.3 & -0.1 & $-0,1$ & 0.2 \\
\hline Exchudins Oil Fund (general government) & -3.5 & .3 .9 & .2 .2 & -3.4 & -2.7 & -2.7 & -2.6 \\
\hline Excluding foreign project loans & 1.0 & 2.3 & 3.2 & 2.1 & 1.8 & 1.8 & 2.1 \\
\hline Non-oil balance & .8 .2 & -9.2 & -7.5 & -8.2 & $\cdots$ & -9.5 & -9.3 \\
\hline \multicolumn{8}{|l|}{ Memorandum items: } \\
\hline Total external assistance, excludiug IMF & 3.6 & 3,4 & 1.9 & 3.6 & 2.6 & 2.6 & 3.3 \\
\hline Project financing & 1.7 & 2.8 & 2.8 & 2.3 & 2.1 & 2.1 & 2.0 \\
\hline Program fingucing & 1.9 & 0.6 & 0.1 & 1,1 & 0.5 & 0.5 & 1,2 \\
\hline Fjnancing gap & 0.0 & 0.0 & 0.0 & 0.0 & 0.0 & 0.0 & 0.2 \\
\hline
\end{tabular}

Sources: Azeri authorities and staff estimates and projections.

1/ Differences to board approved estimates from June 200 j are due to the change to the new classification of monetary accounts and revised tigures for ron-oil revenue is 2000 .

2/ Excludes quasi-fiscal energy sector revenues and expenditures. Revenue and expenditure include 42 billion manat from a grant by Germany which was signed aiter the budget for 2002 was passed. 
Table 7. Azerbaijan: Balance of Payments, 2000-2005

(ln miltions of U.S dolterg)

\begin{tabular}{|c|c|c|c|c|c|c|c|c|c|c|c|}
\hline & \multirow{2}{*}{$\begin{array}{r}2000 \\
\text { Bst. }\end{array}$} & \multicolumn{5}{|c|}{2001} & \multicolumn{2}{|c|}{2002} & \multirow{2}{*}{20003} & \multirow{2}{*}{$\frac{2004}{\text { rojections }}$} & \multirow[t]{2}{*}{2005} \\
\hline & & $\frac{Q 1+Q 2}{\text { Act. }}$ & $\frac{Q^{3}}{\mathrm{PEO}_{\mathrm{O}}}$ & $\frac{84}{80 j}$ & \multicolumn{2}{|c|}{ Year } & Progrem I & Rev, prog & & & \\
\hline Exportte, f.o.b. & 1,877 & 980 & 619 & 427 & 2,121 & 2,025 & 2,022 & 1,593 & 1,753 & 1,743 & 2,345 \\
\hline Of which: oil and other produes & 1,598 & 885 & 563 & 3งร & 1,863 & 1,824 & 2,732 & 1,372 & $1, \$ 12$ & 3,480 & 2,062 \\
\hline other $1 /$ & 279 & 94 & 35 & 53 & 259 & 201 & 290 & 221 & 241 & 263 & 283 \\
\hline Imports, fa.b. & $-1,599$ & $-\$ 51$ & -414 & -397 & $-1, \mathbf{8 5 4}$ & $-1,457$ & $.2,243$ & $-2,055$ & $-2,613$ & $-2,605$ & $-2,563$ \\
\hline Of which: oil seeior & -147 & -60 & -40 & .66 & -282 & .166 & .559 & -651 & $-1,097$ & -593 & -815 \\
\hline alber If & $-1,393$ & -590 & -374 & .326 & $-1,521$ & $-i, 291$ & $-3,6.84$ & $-1,403$ & $-1,5 ! 5$ & $-1,612$ & $-1,778$ \\
\hline Trade bajanse & 338 & 329 & 305 & 35 & 257 & 568 & -221 & -462 & -860 & -863 & -219 \\
\hline Services (net) & .225 & -186 & 98 & -153 & -352 & -438 & -625 & -737 & $-1,137$ & $-1,070$ & -979 \\
\hline Expogts & 260 & 127 & 84 & 64 & 292 & 275 & $3 i 7$ & 295 & 309 & 329 & 351 \\
\hline himports & -485 & -313 & -182 & -218 & -644 & .713 & .942 & $\cdot 1_{r}, 033$ & $-1,446$ & $-1,399$ & $.1,3,30$ \\
\hline Of which: oil sertor & -154 & -129 & -105 & $-13 j$ & .260 & -365 & -502 & -612 & -973 & .905 & .797 \\
\hline Intearte & -310 & -182 & $=100$ & .54 & .367 & -335 & -329 & -259 & .264 & -221 & .376 \\
\hline Investrnent insome (net) & .237 & -140 & .83 & -25 & -281 & -248 & -242 & -177 & -172 & -130 & -285 \\
\hline a/w prefit of oil consortitum & -293 & -162 & -89 & -42 & .358 & -299 & -395 & .219 & .240 & -231 & 404 \\
\hline Compersation of employera & -47 & -26 & -52 & -12 & -45 & -50 & 45 & $-5 \$$ & .55 & .52 & 58 \\
\hline Interese on public debr (hreluding Fund) & -26 & .16 & $-s$ & -16 & -41 & -37 & 42 & -31 & .36 & .35 & -32 \\
\hline Transfers (net) & 73 & 11 & 24 & 16 & 100 & 71 & 98 & 94 & 32 & 49 & 49 \\
\hline Pojvate & 11 & 2 & 10 & 4 & 29 & 35 & 32 & 16 & 16 & 16 & 16 \\
\hline Public & 62 & 29 & 14 & 13 & 71 & 55 & 66 & 79 & 37 & 33 & 33 \\
\hline Curtent accounc balance & -124 & -8 & 30 & -156 & -381 & -134 & $-1,078$ & $-1,364$ & $-2,209$ & $-2,106$ & $-1,525$ \\
\hline Net direct investment & 119 & 12 & 127 & 212 & 314 & 351 & 1,109 & 1,307 & 2,291 & 2,061 & 1,485 \\
\hline Oil sompganies &.-16 & -31 & 101 & 173 & 56.1 & 243 & 933 & 5,191 & 2,172 & $1, \$ 41$ & 1,362 \\
\hline sontracted & 454 & 760 & 257 & 265 & 761 & 783 & 3,471 & 1,528 & 2,513 & 2,765 & $2, \mathrm{DBB}$ \\
\hline cupital tepaurivtion & .569 & -291 & $-16 !$ & .93 & 607 & -545 & -587 & -437 & -491 & -474 & .776 \\
\hline botuls & 100 & 0 & 5 & 0 & 7 & 5 & 50 & 0 & s0 & 50 & 50 \\
\hline Other & 135 & 43 & 26 & 39 & 153 & 108 & 196 & 116 & 119 & 120 & 123 \\
\hline Public aectot capjital & 239 & 59 & 10 & 19 & 166 & 87 & 152 & 131 & 104 & 80 & 76 \\
\hline Medjum Lang-tem bonowing & 257 & 77 & 17 & 36 & 217 & 129 & 209 & 186 & 166 & 135 & $\mathrm{~J} 24$ \\
\hline Budget aupport & 0 & 0 & 0 & $B$ & 0 & 0 & 0 & 30 & 30 & 0 & $\theta$ \\
\hline Otter iongtam lours & 257 & 7 & 17 & 36 & 217 & 129 & 209 & 156 & 136 & 135 & 124 \\
\hline Sebeduled amortization & -18 & -18 & -7 & - & -91 & -41 & -57 & -55 & -63 &.$\$ 5$ & 48 \\
\hline Other (inetuding shart term capital) & 102 & 51 & $4]$ & -23 & 100 & 70 & 100 & 107 & 100 & 100 & 300 \\
\hline Capilal anount belanse & 460 & 122 & 179 & 208 & 580 & 508 & 1,361 & 4,545 & 2,494 & 2,241 & $1,6 \in]$ \\
\hline Enots and orrissions & -96 & $\rightarrow$ & 43 & 0 & -16 & -52 & 0 & 0 & 0 & 0 & 3 \\
\hline Overall bolance & 231 & 105 & 166 & 52 & 213 & 323 & 284 & $18]$ & 286 & 136 & 136 \\
\hline Finencing & -281 & -105 & -166 & -52 & -264 & .323 & -327 & $\cdot 181$ & -290 & .190 & -278 \\
\hline Chastge in Het toreigin tosets of NBA (uncrease $n$ ) & .59 & 6 & -88 & 3 & .35 & .79 & .89 & 30 & .78 & -55 & -101 \\
\hline Net credit from the Fund & .52 & .22 & 4 & -16 & .39 & 54 & +8 & $-s$ & -38 & -34 & $-4]$ \\
\hline Disbursements' purchisses & 0 & 0 & 10 & $a$ & 0 & 10 & 0 & 42 & 32 & 16 & D \\
\hline Repayments/repurchases & .52 & -22 & -6 & -16 & .39 & 44 & 48 & -48 & .70 & -51 & 41 \\
\hline Change in poss official nerves (increase -) & .7 & 28 & -93 & 19 & 4 & -49 & -41 & .24 & -40 & -21 & -60 \\
\hline Change In other Bureign lizbilities (inctense +) & 0 & 0 & 0 & 0 & 0 & 0 & 0 & 0 & 0 & D & 0 \\
\hline Change is errears (destesess -) & 0 & 0 & 0 & 0.2 & 0 & 0.2 & a & -0.2 & 0 & 0 & 0 \\
\hline Change in oil fund astets (o ingreasse) & .247 & 84 & -78 & -55 & -302 & -217 & -239 & -152 & -212 & -135 & .177 \\
\hline Adjustrnent (Oil Fund required reserva) 2 & 25 & -27 & 0 & 0 & .27 & -27 & 0 & 0 & 0 & 0 & 0 \\
\hline Financirg gap $3 /$ & $\theta$ & 0 & 0 & 0 & so & 0 & 44 & 0 & 5 & $5 s$ & 142 \\
\hline Memorandum isens: & & & & & & & & & & & \\
\hline Current account deficit (in percent of GDP) & & & & & & & & & & & \\
\hline Gncludiag vil stetor ingonts & -2.4 & -2.3 & 0.6 & -2.3 & -6.1 & .23 & -173 & -23.4 & -33.3 & -28.4 & $-17,9$ \\
\hline Exciuding oil secur imports & 3.4 & 13.0 & 9.0 & 7,0 & 3.3 & 7.0 & -0.3 & -1.6 & -2.1 & -2.8 & 1.3 \\
\hline Gross official reserves (USS5 inillions) & 680 & $\ldots$ & $\ldots$ & $\ldots$ & 676 & 725 & 217 & 749 & $7 \mathrm{Bg}$ & 810 & 870 \\
\hline Gross official rescrves (ita months of imports e. i.f.) & 3.8 & $\ldots$ & $\ldots$ & $\ldots$ & 2.5 & 2.8 & 2.3 & 2.2 & 2.4 & 2.5 & 3.0 \\
\hline Gross offeial reserves (in months of nom-oil irtigots e.i.f.) & 3.0 & $\ldots$ & $\ldots$ & $\ldots$ & 3.8 & 4.8 & 3.7 & 4.5 & 4.5 & 4.3 & 4.1 \\
\hline Gross ofjicial teserves $f$ broad nonty & 1.2 & $\cdots$ & $\ldots$ & $\ldots$ & 1.0 & 1.J & 0.9 & 1.0 & 0.9 & $\ldots$ & $\cdots$ \\
\hline Oil fund assets & 270 & $\ldots$ & $\ldots$ & $\ldots$ & 472 & 487 & 710 & 698 & 851 & 986 & 1,163 \\
\hline WBO oil priec (USS per barre?) & 28.3 & $\ldots$ & $\cdots$ & ... & 27.2 & 24.1 & 24.4 & 18.5 & 20.0 & 20.0 & 20.0 \\
\hline
\end{tabular}

Sources: Azeri authorities and staff estimates and projections

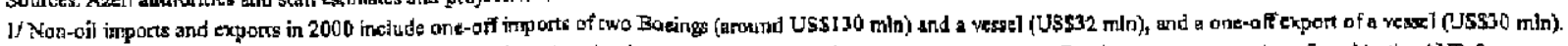

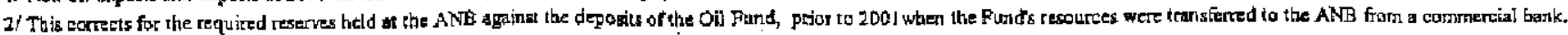


Table 8. Azerbaijan: External Financing Needs and Sources (In millions of US dollars)

\begin{tabular}{|c|c|c|c|c|c|c|c|}
\hline & 1999 & 2000 & 2001 & 2002 & 2003 & 2004 & 2005 \\
\hline Gross financing needs & 876.8 & 447.5 & 481.0 & $1,642.6$ & $2,593.8$ & $2,367.0$ & $1,850.7$ \\
\hline Current account deficit (incl. official transfers) & 588.2 & 110.1 & 120.5 & $1,358.2$ & $2,204.5$ & $2,103.0$ & $1,523.5$ \\
\hline Debt amortization & 13.7 & 18.1 & 41.4 & 55.0 & 62.6 & 55.1 & 47.8 \\
\hline Medium and long-term debt & 13.7 & 18.1 & 41.4 & 55.0 & 62.6 & 55.1 & 47.8 \\
\hline Short term debt & - & - & - & - & -- & - & -- \\
\hline Gross reserve accumulation (+ increase) & 223.9 & 7.0 & 45.3 & 24.4 & 40.0 & 20.8 & 59.7 \\
\hline Oil Fund accumulation (+ increase) & 23.5 & 246.5 & 216.8 & 151.6 & 212.2 & 135.0 & 177.1 \\
\hline IMF repurchases and repayments, and charges & 27.5 & 65.8 & 57.0 & 53.3 & 74.6 & 53.1 & 42.5 \\
\hline Gross financing sources & 876.8 & 447.5 & 481.0 & $1,642.6$ & $2,593.8$ & $2,367.0$ & $1,850.7$ \\
\hline Foreign direct investment (net) & 510.1 & 119.3 & 351.2 & $1,307.3$ & $2,291.0$ & $2,061.1$ & $1,484.8$ \\
\hline Debt financing & 228.2 & 256.8 & 128.8 & 186.0 & 166.4 & 135.2 & 124.0 \\
\hline IMF purchases & 109.8 & -- & 10.0 & 42.4 & 32.3 & 16.2 & - \\
\hline Other flows & 28.7 & 71.4 & -9.0 & 106.8 & 99.6 & 100.0 & 100.0 \\
\hline Financing gap & -- & -- & - & - & 4,5 & 54.5 & 141.8 \\
\hline
\end{tabular}

Sources: Azerbaijan authorities; and Fund staff estimates and projections. 
Table 9: Azerbaijan : Capacity to Repay the Fund, 1999-2005 (In millions of SDR's)

\begin{tabular}{|c|c|c|c|c|c|c|c|}
\hline & \multirow[t]{2}{*}{1999} & \multirow[t]{2}{*}{2000} & 2001 & 2002 & & 2004 & 2005 \\
\hline & & & \multicolumn{5}{|c|}{ Projections } \\
\hline Outstanding use of Fund credit & 296.7 & 257.7 & 230.4 & 226.3 & 196.1 & 168.7 & 135.1 \\
\hline IMF obligations & 20.1 & 49.6 & 45.8 & 42.5 & 59.4 & 42.3 & 33.9 \\
\hline Purchases and Disbursements & 80.3 & 0.0 & $8: 1$ & 33.8 & 25.7 & 12.9 & 0.0 \\
\hline Repporchases and Repayments & 11.7 & 39,0 & 35.3 & 37.8 & 56,0 & 40.3 & 32.6 \\
\hline Charges & 8.4 & 10.6 & 10.4 & 4.7 & 3.4 & 2.0 & 1.3 \\
\hline \multicolumn{8}{|l|}{$\begin{array}{l}\text { Outstanding use of Fund credit } \\
\text { as a ratio of }\end{array}$} \\
\hline Exports of goods and services & 31.6 & 16.0 & 12.8 & 15.5 & 12.3 & 10.6 & 6.6 \\
\hline Exterual public debt & 42.1 & 29.2 & 23.6 & 20.5 & 16.6 & 13.5 & 10.4 \\
\hline Gross official reserves & 60.3 & 50.3 & 40.6 & 39.0 & 32.2 & 27.0 & 20.3 \\
\hline GDP & 8.9 & 6.5 & 5.2 & 5.0 & 3.8 & 3.0 & 2.1 \\
\hline Quota & 184.4 & 160.1 & 143.2 & 140.7 & 121.9 & 104.8 & 84.6 \\
\hline \multicolumn{8}{|l|}{$\begin{array}{l}\text { Debt service obligations to IMF } \\
\text { as a ratio of }\end{array}$} \\
\hline Exports of goods and sevvices & 2.1 & 3.1 & 2.5 & 2.9 & 3.7 & 2.6 & 1.6 \\
\hline External public debt. & 2.9 & 5.6 & 4.7 & 3.9 & 5.0 & 3.4 & 2.6 \\
\hline Gross official reserves & 4.1 & 9.7 & 8.1 & 7.3 & 9.8 & 6.8 & 5.1 \\
\hline GDP & 0.6 & 1.3 & 1.1 & 1.0 & 1.3 & 0.8 & 0.6 \\
\hline Quote & 12.5 & 30.8 & 28.4 & 26.4 & 36.9 & 26.3 & 21.0 \\
\hline $\begin{array}{l}\text { Memorandum item: } \\
\text { quota (million SDR) }\end{array}$ & 160.9 & 160.9 & 160.9 & 160.9 & 160.9 & 160.9 & 160.9 \\
\hline
\end{tabular}

Source: Staff estimates and projections. 


\section{Table 10. Azerbaijan: Prior Actions for the Completion of the First Review, and Structural Performance Criteria and Benchmarks \\ for end-March 2002}

\section{Prior Action}

- Adoption of a program of reforn of the Customs Committee, based on the report of the internationally reputable firm hired to evaluate the Committee, and in consultation with the Fund staff.

- Submission to parliament of a revised law on the Chamber of Accounts, giving this organization the authority to audit all government bodies, including all budgetary and and extra-budgetary funds.

- Issue a decree indicating that subsidies to Azerenergy and Azerigas will be included in the 2003 state budget, and that in 2002 these subsidies will be included in quarterly public reports on the execution of the consolidated government budget.

\section{Structural Performance Criteria}

- Adoption of a timetable for the unification of domestic and export prices for natural gas, oil and oil products.

- Adoption, in consultation with Fund staff, of a timetable for the gradual reduction of the number of specific tariffs and the weighted average tariff, consistent with the commitments in the MEFP.

- Adoption of a timetable for the full privatization of the International Bank, and a timetable for the preparation of the United Universal Joint Stock Bank for privatization.

\section{Structural Benchmarks}

- Submission to Parliament of the new Banking System Law.

- Submission to Parliament of a new Budget Systems Law that is consistent with best international practices.

- Adoption of a concrete timetable for the implementation, in 2002, of all short term elements of the Customs Committee reform program. 
Table 11. Azerbaijan: Review and Phasing of Disbursements Under the Proposed PRGF Arrangement

(In millions of SDRs)

\begin{tabular}{|c|c|c|}
\hline Date of Disbursement & Conditions & Disbursement \\
\hline July 2,2001 & $\begin{array}{l}\text { Disbursed upon Board approval of the } \\
\text { PRGF arrangement }\end{array}$ & 8.05 \\
\hline On or after October 15,2001 & $\begin{array}{l}\text { Completion of the first review; end- } \\
\text { September } 2001 \text { performance criteria }\end{array}$ & 8.05 \\
\hline On or after April 15, 2002 & $\begin{array}{l}\text { Completion of the second review; end- } \\
\text { March } 2002 \text { performance criteria }\end{array}$ & 12.87 \\
\hline On or after October 15, 2002 & $\begin{array}{l}\text { Completion of the third review; end- } \\
\text { September } 2002 \text { performance criteria }\end{array}$ & 12.87 \\
\hline On or after April 15, 2003 & $\begin{array}{l}\text { Approval of the fourth review; end-March } \\
2003 \text { performance criteria }\end{array}$ & 12.87 \\
\hline On or after October 15,2003 & $\begin{array}{l}\text { Completion of the fifth review; end- } \\
\text { September } 2003 \text { performance criteria }\end{array}$ & 12.87 \\
\hline On or after April 15, 2004 & $\begin{array}{l}\text { Completion of final review; end-March } \\
2004 \text { performance criteria }\end{array}$ & 12.87 \\
\hline
\end{tabular}




\section{Azerbaijan: Fund Relations}

As of Novernber 30, 2001

1. Membership Status: Joined: 09/18/1992; Article XTV

2. General Resources Account:

Quota

Fund Holdings of Currency

SDR Million

160.90

\% Quota

306.24

100.0

Reserve position in Fund

0.01

190.3

0.0

3. SDR Department:

$\underline{\text { SDR Million }}$

Holdings

0.59

\%Allocation

N/A

4. Outstanding Purchases and Loans:

SDR Million

Extended arrangements

52.46

$\%$ Ouota

56.32

32.6

Contingency and Compensatory

36.56

35.0

Systemic Transformation

89.95

22.7

PRGF arrangements

5. Financial Arrangements:

\begin{tabular}{lcccc}
\hline Type & $\begin{array}{c}\text { Approval } \\
\text { Date }\end{array}$ & $\begin{array}{c}\text { Expiration } \\
\text { Date }\end{array}$ & $\begin{array}{c}\text { Amount Approved } \\
\text { (SDR Million) }\end{array}$ & $\begin{array}{c}\text { Anount Drawn } \\
\text { (SDR Million) }\end{array}$ \\
PRGF & $07 / 06 / 2001$ & $07 / 05 / 2004$ & 80.45 & 8.05 \\
EFF & $12 / 20 / 1996$ & $03 / 19 / 2000$ & 58.50 & 53.24 \\
ESAF/PRGF & $12 / 20 / 1996$ & $03 / 19 / 2000$ & 93.60 & 81.90
\end{tabular}

6. Projected Obligations to Fund:

(SDR million; based on existing use of resources and present holdings of SDRs):

\begin{tabular}{|c|c|c|c|c|c|}
\hline \multicolumn{2}{|l|}{ Overdue } & \multicolumn{4}{|c|}{ Forthcoming } \\
\hline $11 / 30 / 2001$ & 2001 & 2002 & 2003 & 2004 & 2005 \\
\hline Principal & 0.4 & 37.8 & 56.0 & 40.3 & 32.6 \\
\hline Charges/Interest & 0.2 & 4.3 & 3.1 & 1.9 & 1.2 \\
\hline Total & 0.6 & 42.1 & 59.1 & 42.2 & 33.8 \\
\hline
\end{tabular}

\section{Safeguards assessment}

Under the Fund's safeguards assessment policy, the Azerbaijan National Bank is subject to a full Stage One safeguards assessment with respect to the PRGF that was approved on July 6, 2001 , which is scheduled to expire on July 5,2004. A Stage One safeguards assessment of the Azerbaijan National Bank was completed on December 14, 2001. Based on the preliminary findings of that report, an on-site assessment was conducted from January 7-18, 2002. The mission identified a number of relatively minor safeguards issues. The safeguards assessment report is in the process of being finalized and will be completed before the second review of the PRGF arrangement in June 2002. 


\section{Exchange rate arrangements}

The currency of Azerbaijan is the manat which became sole legal tender on January 1, 1994. Currently, the exchange rate is allowed to float against all currencies. Noncash exchange rates are determined five times a week at the foreign exchange auctions conducted by the Baku Interbank Currency Exchange (BICEX). Exchange rates for cash transactions are quoted by commercial banks licensed to deal in foreign exchange on the basis of market conditions. The Azerbaijan National Bank (ANB) determines an official exchange rate against the U.S. dollar every day, equal to a weighted average of all foreign exchange markets, including the off-auction interbank market, the retail intra-bank market, and the bank note market located in foreign exchange bureaus.

Azerbaijan has been classified by the staff with the group of countries whose exchange rate regimes are managed floats.

\section{Article IV Consultation}

The 2000 Article TV consultation with Azerbaijan was concluded on August 1, 2000.

\section{ROSCs}

A fiscal transparency ROSC module was prepared by FAD (SM/00/278, 12/12/01).

\section{Resident Representative}

Mr. Michael Mered, the Fund's fourth Resident Representative took up his daties in Baku in July 2000 .

\section{Resident Advisers}

An adviser on the establishment of the Treasury in the Ministry of Finance, Mr. Nurcan Aktürk, was stationed in Baku from December 1994 until September 1996. He was succeeded by Mr. B.K. Chaturvedi, whose assigament was extended twice, first through August 2000, and then through May 2001. Mr. B.K.Chaturvedi has been replaced by Mr. A. Khan whose assignment is from May 2001 to March 2002. A technical long-term adviser for tax administration, Mr. Mark Zariski, was stationed in Baku from April 1995 until April 1996. A new advisor on tax administration, Mr. Peter Barrand, has been stationed in Baku since January 2001, and his assignment has recently been extended to November 2002 . Mr. Isaac Svartsman was resident advisor in the ANB for bank supervision and restructuring from September 1998 to April 2001. 
Azerbaijan: Technical Assistance 1995-2002

\begin{tabular}{|c|c|c|}
\hline Fund Dept. & Area of Assistance & Mission Dates \\
\hline $\mathrm{FAD}$ & Social safety net & February 1995 \\
\hline MAE & Central bank operations & March 1995 \\
\hline FAD & Tax administration & April 1995 \\
\hline STA & Balance of payments statistics & April 1995 \\
\hline STA & Monetary statistics & May 1995 \\
\hline MAE & Central bank operations & October 1995 \\
\hline FAD & Treasury project inspection & December 1995 \\
\hline FAD & Tax administration project inspection & December 1995 \\
\hline FAD & Tax policy & February 1996 \\
\hline STA & Balance of payments statistics & March 1996 \\
\hline MAE & Central bank operations and banking sector reform & July/August 1996 \\
\hline $\mathrm{FAD}$ & Treasury project inspection & September 1996 \\
\hline FAD & Expenditure policy & October 1996 \\
\hline FAD & Treasury project inspection & December 1996 \\
\hline STA & Monetary statistics & December 1996 \\
\hline MAE & Foreign exchange management & January 1997 \\
\hline MAE & Financial market development & January 1997 \\
\hline FAD & Tax administration & January 1997 \\
\hline MAE & Multitopic mission & March 1997 \\
\hline STA & Balance of payments statistics & April 1997 \\
\hline MAE & Bank restructuring and payments systems & May 1997 \\
\hline FAD & Tax administration & August 1997 \\
\hline LEG & Tax code legisiation & September 1997 \\
\hline MAE & Multitopic mission & October 1997 \\
\hline FAD & Treasury project inspection & April/May 1998 \\
\hline MAE & Bank restructuring & May 1998 \\
\hline BCS & Book entry system & October 1998 \\
\hline LEG & Tax code legislation & November 1998 \\
\hline FAD & Tax administration & December 1998 \\
\hline LEG & Tax code & Jan./Feb. 1999 \\
\hline STA & Balance of payments statistics & Mar./April 1999 \\
\hline LEG & Tax code & Mar./April 1999 \\
\hline MAE & Bank restructuring & April/May 1999 \\
\hline FAD & Tax administration & Sept./Oct. 1999 \\
\hline MAE & Bank restructuring & Oct./Nov. 1999 \\
\hline STA & Price statistics & November 1999 \\
\hline STA & National accounts statistics & November 1999 \\
\hline FAD & Tax administration & Jan. $/ F e b .2000$ \\
\hline FAD & Customs administration & March/April 2000 \\
\hline FAD & Expenditure policy & April/May 2000 \\
\hline LEG & Tax code & September 2000 \\
\hline MAE & Bank restructuring & October 2000 \\
\hline FAD & Treasury computerization & Oct./Nov. 2000 \\
\hline STA & Price statistics & November 2000 \\
\hline
\end{tabular}




\begin{tabular}{lll}
\hline Fund Dept. & Area of Assistance & Mission Dates \\
\hline STA & National accounts and GDDS & November 2000 \\
STA & Money and banking statistics & Nov/ Dec. 2000 \\
STA & National accounts and GDDS & February 2001 \\
STA & Price statistics & February 2001 \\
STA & Balance of Payments Statistics & April 2001 \\
MAE & Banking supervision & May 2001 \\
MAE & Payments system & May 2001 \\
MAE & Central Bank Internal Audit & June 2001 \\
FAD & Customs Administration & June 2001 \\
FAD & Budget systens law & August 2001 \\
MAE & Bank restructuring and monetary operations & June 2001 \\
TRE & Safeguards assessments & January 2002 \\
LEG/MAE & Banking legislation & January 2002 \\
MAE & Central Bank accounting & January 2002 \\
MAE & Payments systern & February 2002 \\
& &
\end{tabular}

Source: International Monetary Fund. 


\section{Azerbaijan: Relations with the World Bank}

Azerbaijan became a member of the IBRD in September 1992 and of the International Development Association in late March 1995.

The current Bank assistance strategy focuses on four main areas: (i) establishment of a policy and instintional framework conducive to efficient and equitable private sector led sustainable growth; (ii) enhancement of competitiveness in critical economic sectors, largely in agriculture; (iii) alleviating poverty; and (iv) resettlement and rehabilitation of Internally Displaced Persons (IDPs). In addition to the above, environment was identified as an urgent issue that the Bank should address. A Country Assistance Strategy was last issued on November 29, 1999 for FY00-02; the next Country Assistance Strategy for FY03-05 is planned for October 2002.

As of December 31,2001 , the Association has committed US $\$ 461.6$ million for 16 operations, of which US\$256.1 million has been disbursed: Petroleum Technical Assistance (US\$20.8 million, approved April 1995); Baku Water Supply (US\$61 million, approved June 1995); Institution Building Technical Assistance (US\$18 million, approved July 1995); Rehabilitation Loan (US\$65 million, August 1995); Gas Rehabilitation (US\$20.2 million, September 1996); Farm Privatization (US\$14.7 million, January 1997); Structural Adjustment Credit (US\$70 million, July 1997 and US\$7 million, March 1999); Urgent Environment Investment (US\$20 million, June 1998); Pilot Reconstruction (US\$20 million, July 1998 and US\$10 million, June 1999), Education Reform (US\$5 million, May 1999), Cultural Heritage Preservation (US\$7.5 million, May 1999); Agriculture Development and Credit (US\$30 million, June 1999);

Irrigation/Drainage (US\$42 million, June 22, 2000); Financial Sector Technical Assistance (US\$5.4 million, June 2001); Health Reform (US\$S million, June 2001) and Highway (US\$40 million, June 2001). Due for Board approval this fiscal year 2002 is a Institutional Building Technical Assistance $\Pi$ (US\$16.8 million) as well a supplemental credit for Baku Water Supply (US\$12.9 million). A Structural Adjustment Credit II (US\$60 million) is underway and planned for Board presentation in the second half of fiscal year 2002 .

The following economic and sector work has also been undertaken: a Country Economic Memorandum in September 1993; an energy sector review in December 1993; studies on the agriculture and financial sectors in July and October 1995, to determine sectoral performance, prospects and constraints; a poverty assessment in February 1996; a National Environmental Action Plan was finalized in cooperation with the government in December 1997; a credit worthiness analysis was made in February 1998 and an energy sector update was completed in June 1998. For 1999, a Public Sector Strategy paper was completed and a Public Sector Reform Workshop was held in March 1999. Work on trade support initiated in FY98 was completed in June 1999, as were informal notes on pension reform (June 1999) and infrastructure privatization (April 1999). For 2000, besides a report on Water and Wastewater, a multi-country paper on Caspian Oil and Gas was presented at the Annual Meetings 2000 in Prague - follow-up efforts continue in 
2002. In addition, a Rural Sector and Infrastructure Report and the Country Economic Memorancum were completed in 2001. Advisory services continue to be provided to the financial and private sectors, including on Environmental Permitting, and Electricity. Due to be completed in June 2002 are the Poverty Assessment, the Country Financial Accountability Assessment and the Country Procurement Assessment Report. The Bank and the IMF assisted the Government in the preparation of an Interim Poverty Reduction Strategy Paper (IPRSP), which was presented in July 2001 - the full PRSP is planned for September 2002. 


\section{REVision of MONETARY DATA}

Since the approval of the three-year PRGF arrangement and the issuance of the Staff Report (EBS/01/91) in June 2001, Azerbaijan's monetary statistics have undergone significant accounting changes, necessitated by four main developments: the reclassification of some monetary accounts, the removal of the Oil Fund and Agroprom Bank from the monetary survey as of June 2001, and the revision of the amount of Agroprom Bank's debt to the ANB that was to be taken over by the government. The purpose of this appendix is to present these changes and to demonstrate their cumulative impact on the monetary aggregates, in order to facilitate the reading of the monetary tables, and in particular the comparison between program targets and actual results. These changes are presented in the attached Appendix IIITable 1(Summary accounts of the ANB) and Appendix III-Table 2 (Monetary survey).

\section{A. Reclassification of Some Monetary Accounts}

In November/December 2000, an STA mission conducted a thorough analysis of Azerbaijan's monetary statistics and found some methodological weaknesses in the compilation of monetary statistics, in the form of misclassifications of various monetary accounts. ${ }^{1}$ Almost all the monetary aggregates were modestly affected by these misclassifications, including net domestic assets (NDA) of the ANB, the ANB's net credit to the general government, total net credit to the general government by the banking system, total credit to the economy, broad money and the net external position of the commercial banks. On the fiscal side, the estimation of the overall deficit was also affected, as this aggregate is defined from the financing side, and hence was affected via the net credit to the general government by the banking system. To redress these weaknesses, the STA mission recommended a new classification of monetary accounts that was adopted by the authorities. ${ }^{2}$

\footnotetext{
${ }^{1}$ This issue was noted in EBS/01/91(Para. 43). The necessary reclassification of the accounts was discussed with the authorities and understanding was reached that program performance would be assessed on the basis of the new classification of monetary accounts. The staff has done a thorough analysis of the purchases made under the old program and concluded that these misclassifications did not result in any case of misreporting.

${ }^{2}$ These misclassifications include, inter- alia, several government accounts with the ANB and commercial banks, which were previously treated as other liabilities (in other items net, OIN), and are now incorporated into the government's net position vis-a-vis the ANB and the commercial banks, respectively; some commercial banks' gross claims on the general government which were mistakenly treated as claims on the private sector, and bave been reclassified as claims on general government; and government foreign currency deposits which were previously included in broad money, and are now part of the govenment's net financial position vis a vis the banking system.
} 
Tables $1 \mathrm{~b}$ and $2 \mathrm{~b}$ compare the program targets as approved by the Executive Board, (first column) and the adjusted program numbers based on the new classification of monetary accounts (second column). The adjusted data bave been estimated on the basis of the March 2001 monetary accounts under the new classification, and derived by using the flows of the monetary program. For example, in Table 1.b., the program target for net credit to the general government for end-September 2001 was 166 billion, corresponding to a cumulative increase of manat 328 billion since April 1, 2001; and the adjusted program target is manat 169 billion, corresponding to an identical flow during the same period. In Table 2.b, credit to the economy was programmed to reach mana 2,452 billion in September 2001 (manat +32 billion); and the adjusted program target is manat 2,274 billion as against manat 2,242 billion at end-March 2001 (+manat 32 billion).

\section{B. The Removal of the Oil Fund}

At the time of program approval, the Oil Fund was part of the monetary survey, mainly for transparency reasons but also for practical reasons because all the Fund's resources were managed by the ANB and appeared in its balance sheet; the ANB's balance sheet was, to that effect, the main source of information regarding the Oil Fund assets. However, starting in August 2001, following the enactment of the regulations on the Oil Fund's asset management, the Management of the Oil Fund took over the responsibility of managing and investing the oil fund assets, and established its own periodic reporting on the Fund's financial situation. In view of this new situation and the fact that the Oil Fund has no monetary impact, the staff has decided to remove it from the monetary survey and the summary accounts of the ANB; in these last two tables, the Oil Fund was treated as part of foreign assets on the asset side and as government deposits on the liability side.

Tables 1.c and 2.c compare program targets and the adjusted program targets taking into account the cumulative effect of the new classification and the removal of the Oil Fund from the monetary framework starting in June 2001. Compared with $1 . \mathrm{b}$ and $2 . \mathrm{b}$, the affected aggregates are the net foreign assets of the ANB and the net foreign assets of the banking system, which previously comprised also the oil fund assets; and the net domestic assets of the ANB and the net domestic assets of the banking system, which no longer comprise the Oil Fund's deposits.

\section{The Removal of the Agroprom Bank}

The removal of Agroprom Bank from the monetary survey dates back to May 2001 and followed the withdrawal of the bank's banking license, and the transformation of Agroprom into a nonbank financial institution. ${ }^{3}$ The summary accounts of the bank at the time of the removal of its license cculd be summarized as follows (in manat billion); net foreign assets

\footnotetext{
${ }^{3}$ At the time of the preparation of the board documents, Agroprom's summary accounts were not available, which is why the withdrawal of Agroprom's banking license could not be reflected in the monetary program.
} 
$(-8)$; net domestic assets ( +28$)$, including net claims on general government $(-70)$, credit to the economy ( +596$)$ and other items net $(-498)$; and deposits, essentially in foreign currency, $(+20)$.

Tables $1 . \mathrm{d}$ and $2 . \mathrm{d}$ compare program targets and the adjusted program targets taking into account the cumulative effect of the new classification and the removal of the Oil Fund and Agroprom Bank from the monetary framework. While the removal of Agroprom has not affected the summary accounts of the ANB (Table 1.d) ${ }^{4}$, it has affected all the aggregates of the monetary survey. In order to make the adjusted program targets and actual results comparable and to have the flows in the adjusted program equate to those in the program, the end-March 2001 data, which is the base for the adjusted program targets, were adjusted by removing the Agroprom aggregates.

\section{The Revision of Agroprom's Debt to the ANB.}

Following the withdrawal of Agroprom's banking license, the ANB and the Ministry of finance (MOF) signed a convention transferring Agroprom's debt to the ANB to the government. This convention was reflected in the monetary survey (and in the program targets) in the form of an increase in the ANB's claims on general government by manat 258 billion, the provisional estimate of the debt, and a decline by an equivalent amount in the ANB's claims on banks. In August 2001 (after the approval of the PRGF arrangement), and following an exhaustive census and a detailed study of all the loans that would qualify for this operation, the ANB and the MOF agreed to revise upward the amount of this debt by manat 46 billion to manat 304 billion.

Tables 1.e and 2.e compare program targets and the adjusted program targets taking into account the cumulative effect of the new classification, the removal of the Oil Fund and Agroprom Bank, and the upward revision of Agroprom Bank's debt taken over by the govermment. Compared with 1.d and 2.d, the affected aggregates are (in manat billion); net claims on general government $(+46)$, and claims on banks $(-46)$ for the summary accounts of the ANB; and net claims on general government $(+46)$ and other items net $(-46)$ for the monetary survey.

\section{E. The Total Impact of the Revisions}

The attached Tables 1.f and 2.f. summarize the total impact of the revisions described above on the monetary data, and compare for each quarter of the period December 2000-December 2001 , the program targets, the adjusted program targets and the actual results.

\footnotetext{
${ }^{4}$ Agroprom's debt vis a vis the ANB has been transferred to the government, see section D.
} 
Table 1. Azerbaijan: Summary Accounts of the Axerbaijan National Bank, 2000-02 (In billons of manuts)

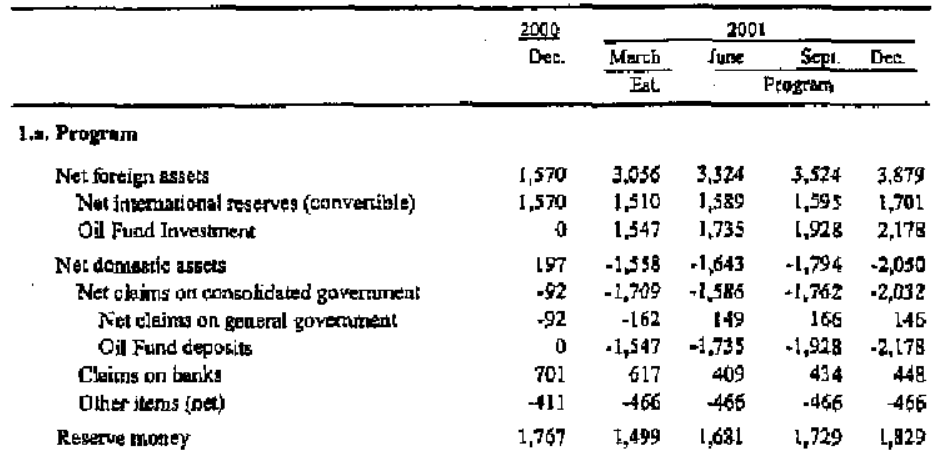

1.b. Incorporatiog the effect of the reclaseffication of the gorermanent accouds

\begin{tabular}{|c|c|c|c|c|c|c|c|c|c|c|}
\hline & \multicolumn{2}{|c|}{2000} & \multicolumn{8}{|c|}{2000} \\
\hline & \multicolumn{2}{|c|}{ D. } & \multicolumn{2}{|c|}{ Warati } & \multicolumn{2}{|r|}{ Junge } & \multicolumn{2}{|c|}{ Sen } & \multicolumn{2}{|c|}{ Def, } \\
\hline & Prog. & Adj, & Prog & Adj. & Prog. & AG. & Prog. & Ad]. & PFog: & Adt. \\
\hline Nex foreigat assets & 1,570 & 1,569 & 3,056 & 3.044 & 3,324 & 3,311 & 3,524 & 3,511 & 3,979 & 3,865 \\
\hline Net international reserves & 1,570 & 1,569 & 1,510 & 1,496 & 1,589 & 1,576 & 1,595 & 1,582 & 1,701 & 1,688 \\
\hline Oil Fund Investment & 0 & 0 & 1,547 & $t .547$ & 1.735 & 1,739 & 1,928 & 1,929 & 2.178 & 2,172 \\
\hline Nat domestic asiels & 197 & 199 & $-1,558$ & $-1,544$ & -1.643 & .1 .629 & .1 .794 & $-1,7 \mathrm{BI}$ & $-2,050$ & $-2,036$ \\
\hline Wet claing on consolidented goverament & -92 & -90 & $-1,709$ & $-1,306$ & $-1,586$ & $-1,583$ & $-1,762$ & $-1,760$ & $-2,032$ & $-2,029$ \\
\hline Net claims or general governument & -92 & -90 & +162 & -153 & 149 & 152 & 16.6 & 169 & 146 & 149 \\
\hline Oil Fund deposiv & i & 0 & $-i, 547$ & $-1,547$ & $-1,735$ & $-1,735$ & -1.928 & $-1,928$ & $-2,178$ & $-2,178$ \\
\hline Claims on banks & 701 & 701 & 617 & 617 & 409 & 409 & 434 & 434 & 448 & 448 \\
\hline Other items (net) & .411 & -413 & -466 & -456 & 466 & 456 & -465 & .456 & -466 & 456 \\
\hline Reserve montr. & 1,767 & 1.767 & 1,499 & 1,499 & 1.081 & 1,681 & 1,729 & 1,729 & 1,829 & 1,829 \\
\hline \multicolumn{11}{|c|}{ Le. Ineorporeting the rede salfeadon efreet and ameludling the Oll Fund } \\
\hline Net Etoreign assets & 1,570 & 1,569 & $3,0,66$ & 1,496 & 3,324 & 1,576 & 3,524 & 1,582 & 3,879 & 1,688 \\
\hline Nat demestic assels & 197 & 199 & $-1,358$ & 3 & $-1,643$ & 105 & $-1,794$ & 147 & $-2,050$ & 142 \\
\hline
\end{tabular}

1.d. Incorporating the reclusallication eficrl, and excluding the Oil Fund and Agraprom haqk; same us 1.e as the removel of Aproprom tar oa effects on the AriB.

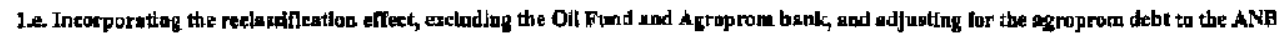

\begin{tabular}{|c|c|c|c|c|c|c|c|c|c|c|}
\hline Net dofieftic asoets & 197 & 199 & $=1,558$ & 3 & $-1,643$ & 105 & $-1,794$ & 147 & $-2,050$ & 142 \\
\hline Net cleims on tobolidated government & -92 & -90 & $-1,709$ & -159 & $-1,586$ & 198 & -1.762 & 215 & $-2,032$ & 195 \\
\hline Ofw; Net elains on general government & -162 & $\mathbf{9 0}$ & -162 & .159 & 149 & 198 & 1.66 & 215 & 146 & 195 \\
\hline Claims on barks & 701 & Jol & 617 & 6.7 & 409 & 353 & 434 & 3888 & 448 & 402 \\
\hline
\end{tabular}

1.f. Incorporating 메 effects

\begin{tabular}{|c|c|c|c|c|c|c|c|c|c|c|c|c|c|c|c|}
\hline & \multicolumn{3}{|c|}{20,00} & \multicolumn{12}{|c|}{2001} \\
\hline & \multicolumn{3}{|c|}{$D_{\text {ex }}$} & \multicolumn{3}{|c|}{ Manth } & \multicolumn{3}{|c|}{ Ilype } & \multicolumn{3}{|c|}{ Sopl. } & \multicolumn{3}{|c|}{ Deg. } \\
\hline & Frog. & Afl Adj. & Act. & Prog & Aet, Adj. & Ant & Prog: & Pog. Adj, & Act. & Prog. & Prog. Adj. & Acth & Prog. & Prog, hadj. & AsL \\
\hline Nel foreign assets & 1,570 & 1,569 & 1.569 & $3,0,56$ & 1.496 & 1,496 & 3,324 & 1,576 & 1,605 & $3,52,4$ & 1,582 & 2,011 & 3,879 & 1,688 & 1,975 \\
\hline Nol donestic assets & 197 & 199 & 199 & $-1,598$ & 3 & 3 & $+1,643$ & 105 & -93 & $-1,79 \mathrm{~d}$ & 147 & -402 & $-2,0 \leqslant 0$ & 142 & -180 \\
\hline Net alaitur on consolidared gaverament & .92 & .90 & .90 & -1.709 & -159 & .159 & $.1,586$ & 198 & 172 & $-1,762$ & 215 & -22 & $-2,032$ & 15.5 & 142 \\
\hline O/w: Net taiths on general goyemment & -92 & .90 & 90 & -162 & -159 & $\cdot 159$ & 149 & 198 & 172 & 166 & 215 & -22 & 146 & 195 & 142 \\
\hline Claims on banks & $70 !$ & 701 & 701 & $6 ! 7$ & 617 & 617 & 409 & 363 & 197 & 434 & 388 & 86 & 448 & 402 & 101 \\
\hline Other iterns (aet) & -411 & -413 & -413 & -456 & -456 & .456 & -465 & -456 & -462 & .466 & -456 & -466 & 466 & 456 & .423 \\
\hline Regerve money & 1,767 & 1,767 & $3,7,67$ & 1,499 & 1,499 & 1,499 & 1.58 .1 & $1,68]$ & 1,512 & 1,720 & 1,730 & 1,609 & 1,829 & 1,829 & 1,795 \\
\hline
\end{tabular}




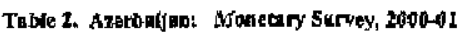
(In blltsans of manats)

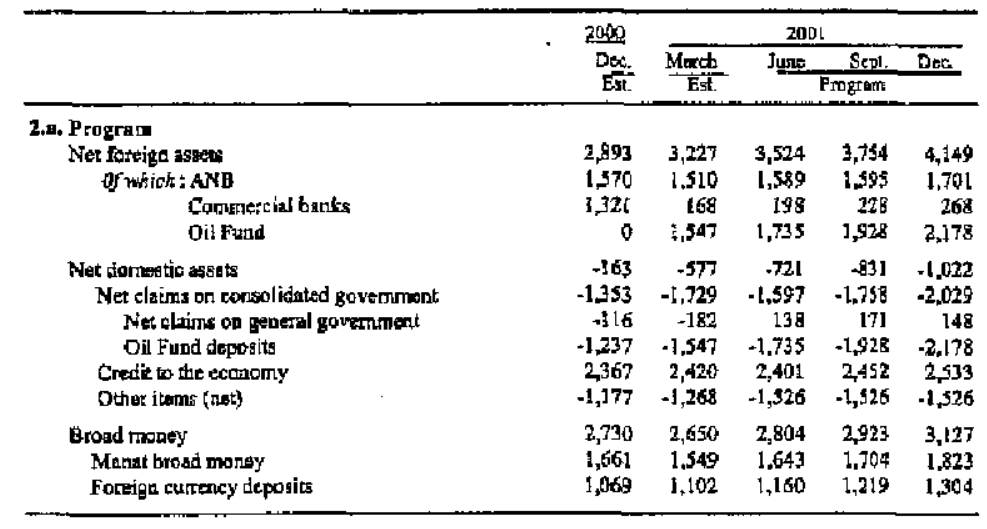

1014.4

2.b. Incorporating the effert of the reclassifleztion of the goverament gceounts

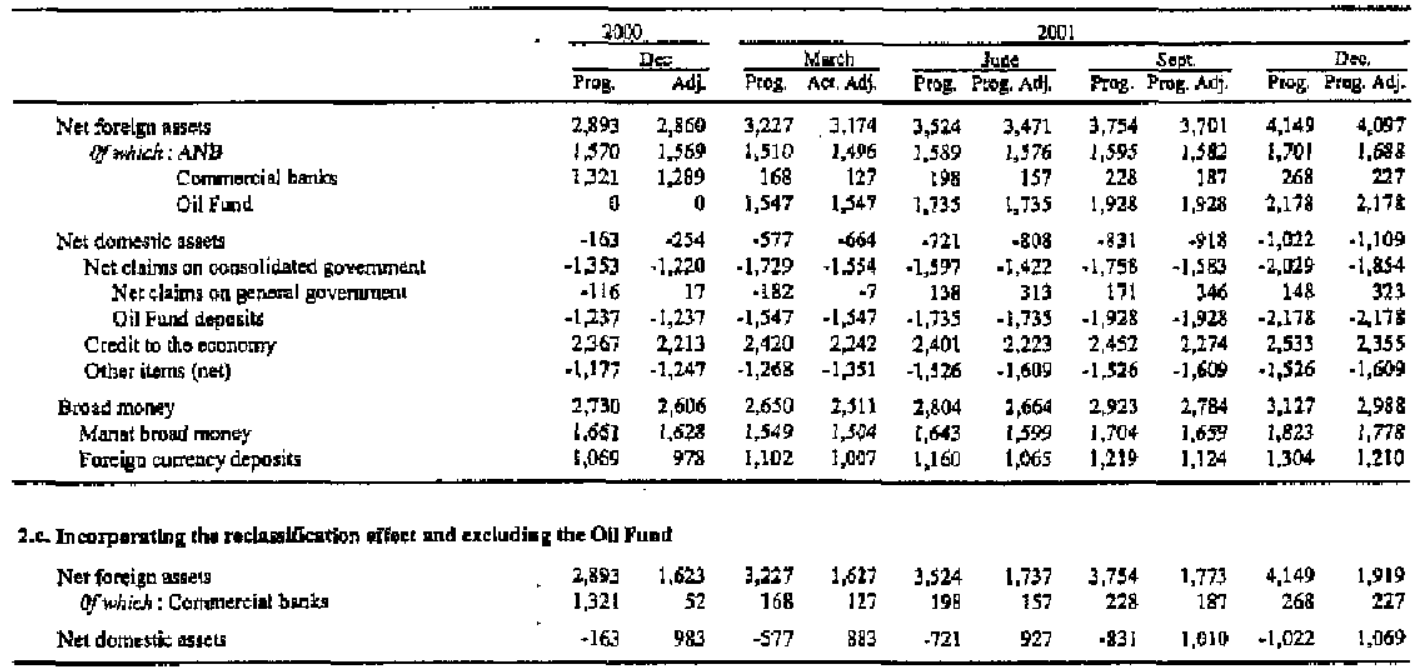

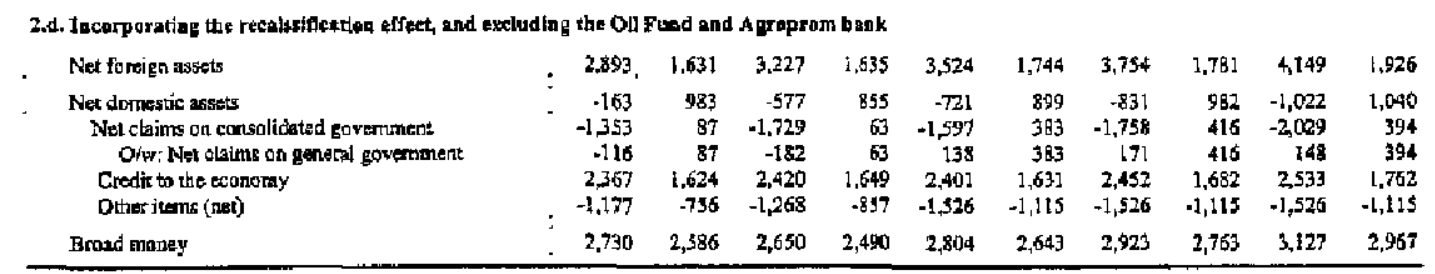

2.e. Ineorporating the reclassification effect, excluding the Oil Furud and Aproprom bank, wd adjustling for the agroprom debt to the ANB

\begin{tabular}{|c|c|c|c|c|c|c|c|c|c|c|}
\hline $\begin{array}{l}\text { Net dornestic agsets } \\
\text { Otw : Net clains or general government } \\
\text { Other therns (net) }\end{array}$ & $\begin{array}{r}-163 \\
-116 \\
-7,177\end{array}$ & $\begin{array}{r}983 \\
87 \\
-796\end{array}$ & $\begin{array}{r}-377 \\
-182 \\
-1,268\end{array}$ & $\begin{array}{r}855 \\
53 \\
-857\end{array}$ & $\begin{array}{r}-721 \\
138 \\
-1,526\end{array}$ & $\begin{array}{r}899 \\
429 \\
-1,161\end{array}$ & $\begin{array}{r}-831 \\
171 \\
-1,526\end{array}$ & $\begin{array}{r}982 \\
462 \\
-1,16 !\end{array}$ & $\begin{array}{r}-1,022 \\
148 \\
-1,525\end{array}$ & $\begin{array}{r}1,040 \\
440 \\
-1,16 !\end{array}$ \\
\hline
\end{tabular}

2.f. Incorporathg all ufects

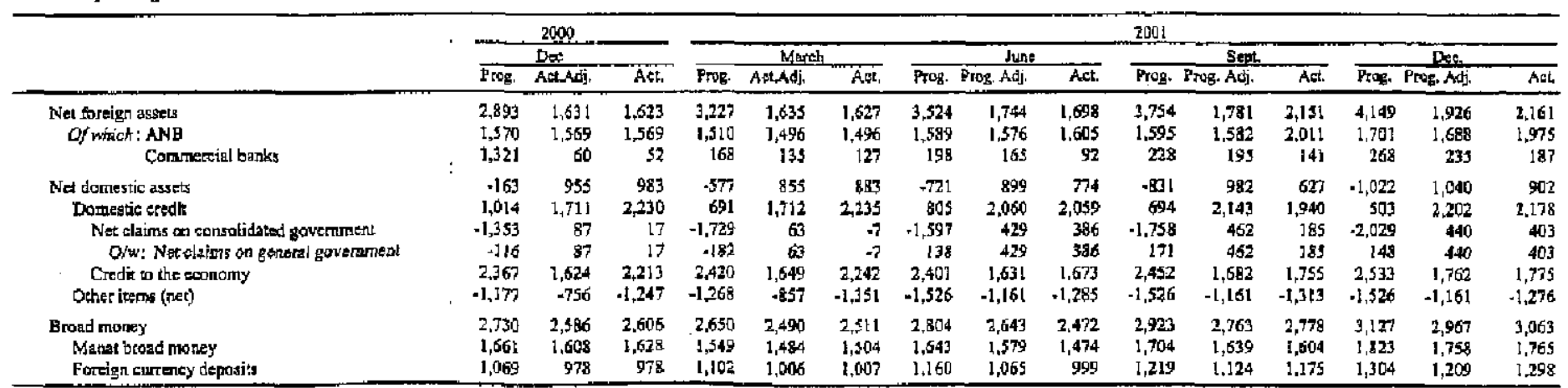




\section{Azerbaijan: Statistical Issues}

Several major issues need to be addressed in the areas of balance of payments, national accounts, and consumer and producer prices. In this connection, extensive technical assistance has already been provided by the Fund (five STA missions since November 2000). It will be important for the authorities to persevere with the implementation of the recommendations derived from this assistance.

\section{Government finance statistics}

The Treasury system has significantly improved with the assistance of an FAD resident advisor, and commitment accounting, introduced from January 1, 1999, is working well. A verification system has also been in place since end-2000. Nonetheless, more work is needed on data on public sector employment and wages.

\section{Money and banking statistics}

An end-2000 STA mission conducted a thorough review of the monetary statistics produced by the Azerbaijan National Bank (ANB), following the full migration to a 3-digit chart of accounts for the ANB and the introduction of a new 4-digit chart of accounts for other depository corporations. The mission also developed new reporting forms to be submitted monthly in an electronic format to STA, and made recommendations to improve the presentation of the analytical balance sheet of theANB. The authorities were in agreement with the mission's recommendations and are now reporting to the Fund on a regular basis. Additional technical assistance in monetary statistics and general statistical organization matters will be provided after the new 4-digit chart of accounts of the ANB becomes fully operational.

\section{External sector statistics}

Weaknesses in the balance of payments compilation include: (i) the fact that vatuation changes of foreign assets and liabilities of the banks and the foreign exchange component of reserve assets are not taken into account in compiling the transactions data; (ii) the fact that the components of gross reserves are not adequately identified; (iii) compilation of nonguaranteed external debt and international investment position data; (iv) pcor data on migrants' transfers; and (v) poor information on non-oil sector foreign direct investments and other capital flows. An STA mission provided assistance on balance of payments and external debt statistics in March-April 2001.

\section{National accounts}

An STA mission visited Baku in February 2001 to address the serious weaknesses in Azerbaijan's national accounts, including most notably a substantial underestimation of the contribution of the oil sector. The authorities have made significant progress in correcting 
this underestimation since then. However, for several economic activities the source data remain weak and the compilation methodology is inaccurate.

\section{Price statisties}

Good progress has been made towards developing a producer price Index (PPI). Three STA missions were undertaken since November 1999 to assist the authorities in developing the PPI. The last of these missions, in February 2001, assisted the authorities in making the final preparations for the calculations and publication of the index. The authorities have started to publish a PPI for the first time in 2001.

A November 1999 STA mission reported major weaknesses in the Consumer Price Index (CPI). The mission reported that specific attention should be paid to the basket of goods and services used and the procedures for updating the weights. The February 2001 price statistics mission made a start in helping the authorities to prepare a new CPI. However, the new household budget survey, on which the new CPI will be based, has not been completed yet. 
Table I. Azerbaijan: Core Statistical Indicators

(As of January 10, 2002)

\begin{tabular}{|c|c|c|c|c|c|c|c|c|c|c|c|c|}
\hline Date of latest observation & $\begin{array}{l}\text { Exchange } \\
\text { Rates } \\
\text { End-Dec. }\end{array}$ & $\begin{array}{c}\text { International } \\
\text { Reserves } \\
\text { End-Dec. } \\
\end{array}$ & \begin{tabular}{|c|} 
Central Bank \\
Balance Sheet \\
End-Dec. \\
\end{tabular} & $\begin{array}{c}\text { Reserve/ Base } \\
\text { Money } \\
\text { End-Dec. }\end{array}$ & $\begin{array}{c}\text { Broad } \\
\text { Money } \\
\text { End-Dec. }\end{array}$ & $\begin{array}{c}\text { Interest } \\
\text { Rates } \\
\text { End-Dec. }\end{array}$ & $\begin{array}{c}\text { Consumer } \\
\text { Price Index } \\
\text { End-Dec. } \\
\end{array}$ & $\begin{array}{l}\text { Exports/ } \\
\text { Imports } \\
\text { Q3 2001 }\end{array}$ & $\begin{array}{c}\text { Current } \\
\text { Account } \\
\text { Balance } \\
\text { Q3 2001 }\end{array}$ & $\begin{array}{c}\text { Overall } \\
\text { Government } \\
\text { Balance } \\
\text { Q3 2001 } \\
\end{array}$ & $\begin{array}{c}\text { GDP } \\
\text { End-Nov. }\end{array}$ & \begin{tabular}{|c} 
Extemal Public \\
Debt/debt service \\
Q3 2001 \\
\end{tabular} \\
\hline Date received & $\operatorname{Fan} .8$ & Jan. 8 & $\operatorname{San} 8$ & Jan. 8 & Jan. 8 & $\operatorname{Jan} .8$ & $\operatorname{Jan} 7$ & Dec. 5 & Dec. 5 & Dee. 5 & Dec.15 & Oct. 26 \\
\hline Frequency of data & D & D & D & D & D & W & M & $\mathbf{M}$ & $\mathrm{Q}$ & Q11 & M & $Q$ \\
\hline Frequency of reporting & D & D & D & $\mathrm{D}$ & D & W & $\mathbf{M}$ & $\mathbf{M}$ & $Q$ & $\mathrm{Q}$ & $\mathbf{M}$ & Q \\
\hline Source of data & A & $\mathrm{A}$ & A & $A$ & A & A & $A$ & A & A & A & A & $\mathbf{A}$ \\
\hline Mode of reporting & C & C & $\mathrm{C}$ & $\mathrm{C}$ & $\mathrm{c}$ & C & C & C & $\mathrm{C}$ & $\mathrm{C}$ & $c$ & $\mathrm{v}$ \\
\hline Confidentiality & $\mathbf{u}$ & $\mathrm{U}$ & $\mathbf{U}$ & $\mathrm{U}$ & $\mathrm{U}$ & $\mathrm{U}$ & $\mathbf{U}$ & $\mathrm{U}$ & $\mathrm{U}$ & $\mathrm{U}$ & $\mathbf{U}$ & B \\
\hline Frequency of publications & D & $M$ & $\mathbf{M}$ & $M$ & $\mathbf{M}$ & $W$ & $M$ & $M$ & $Q$ & $Q$ & $\mathbf{M}$ & $Q$ \\
\hline
\end{tabular}

1/ Deficit calculated from data on financing.

Explanation of abbreviations:

Frequency of data, reporting and publication: D-daily, W-weekly, M-monthly, Q-quarterly.

Soturce of data: A-direct reporting by Central Bank, Ministry of Finance, or other official agency.

Mode of reporting: C-electronic mail or facsimile; $\mathrm{V}$-staff visits.

Confidentiality: U-unrestricted use; B-for use of the Staff and the Executive Board prior to publication. 


\section{AZERBaIJaN: Technical CONSUltation Note}

1. This note summarizes technical assistance (TA) provided to Azerbaijan by the Fund for the past two to three years. Over this period, Azerbaijan has received assistance from the Fiscal Affairs, Monetary and Exchange Affairs, Statistics, Legal, and the Technology and General Services Departments. It also covers future TA needs.

\section{FISCAL AFFaIRs DEPARTMENT (FAD)}

2. The Fiscal Affairs Department has recently provided technical assistance to Azerbaijan in many areas, including public expenditure management, fiscal transparency, tax administration, customs administration, and public expenditure policy. FAD resident advisors are currently installed in the areas of tax administration and treasury computerization.

\section{A. Public Expenditure Management and the Treasury}

\section{Over the past four years, Azerbaijan has received significant assistance in} implementing and expanding the treasury with the aid of a resident treasury advisor. Initially, this TA focused on creating a single treasury account, which the central treasury has been operating since 1998. Subsequently, the resident advisor focused on expanding treasury coverage and reporting procedures, improving commitment accounting and financial planning, improving the budget classification, improving the quality of financial planning, strengthening commitment controls, and establishing registration of verification. In March 2001, a new treasury advisor began a 9-month assignment that focuses on development of a Government Financial Management Information System (GFMIS) for the treasury. The authorities have stressed the need for continuing TA in this area.

4. Treasury operations and control have improved markedly in the last several years as a direct result of FAD assistance. The implementation of the single treasury account and expenditure controls has significantly reduced budgetary arrears and improved financial planning. Assuming the successful completion of the current treasury advisor's assignment, a second assignment should begin sometime in early 2002 and is expected to cover the transition from the pilot phase to full implementation of the GFMIS project.

\section{B. Fiscal Transparency}

5. A mission in February 2000 assisted the authorities in performing an assessment of fiscal transparency, a Report on the Observance of Standards and Codes (ROSC). The Report noted the need to publish reports on the execution of the budget on a more regular basis, enhance the information and analysis provided in the budget, ensure the transparency of Oil Fund operations, strengthen the credibility and capacity of the external audit function, rationalize and simplify regulation of the private sector, and make relations between the government and public sector enterprises more transparent by quantifying, reporting, and eventually eliminating quasi-fiscal activities. 
6. As part of a reform program supported by a Poverty Reduction and Growth Facility (PRGF) arrangement approved July 2, 2001, the authorities are taking steps to address some of the issues noted in the ROSC. Specifically, they have adopted regulations on management of the Oil Fund's assets, committed to published audits of the Oil Fund and to run all nonoperational expenditures of the Oil Fund through the state treasury, established a supreme audit authority, removed some regulatory responsibilities from state-owned enterprises, and committed to making quasi-fiscal utility subsidies explicit in the 2002 budget. An FAD mission visited Baku in August 2001 to provide recommendations on a new organic budget law, which is intended to codify many of the budgetary and transparency reforms. The authorities have requested additional TA in implementing the new budget systems law.

\section{Tax Administration}

7. Following a December 1998 mission on tax administration and in response to the authorities' request for additional technical assistance, $F A D$ assigned a peripatetic expert to Azerbaijan to follow up on the mission's recommendations and to provide additional technical advice. The expert foeused, in particular, on three main areas: (1) changes to the Tax Code which were needed to clarify taxpayers' rights and obligations and to ensure that the tax administration could appropriately carry out its work; (2) reforms in basic tax administration procedures (e.g., taxpayer registration, filing and payment procedures, audit, enforced collection, and taxpayer services); and (3) implementation of modern tax administration procedures in the large taxpayer unit. Based on progress made as a result of this TA, FAD approved the assignment of a long-term tax administration advisor to follow up on these issues starting July 2000 . This assignment was recently extended to September 2002. The advisor will belp the authorities to broaden self-assessment, modernize filing and payments procedures, improve andit and enforcement capacity, strengthen the Large Taxpayer Unit, and improve taxpayer services. The Ministry of Tax has indicated to be especially interested in utilizing this TA to strengthen internal and taxpayer auditing capacities.

8. An assessment of technical assistance to Azerbaijan in tax administration during the past two to three years must take into account the fact that the tax administration at the start of reform program had a weak structure and was under-resourced. Moreover, the tax administration faced the task of implementing a new tax code, with tax officials having received relatively little training in the contents of the new code and with weak understanding of the new code's provisions. Against this background, progress has been positive, but slow. Efforts are still required in a number of critical areas, and substantial progress will need to be made in the last quarter of 2001 if $\mathrm{FAD}$ is to continue its assistance to the tax administration.

\section{Customs Administration}

9. Over the past several years, FAD has provided advice on customs administration on several occasions. On the request of the authorities, an April $2000 \mathrm{FAD}$ mission conducted a diagnosis of the State Customs Committee (SCC)'s organization and procedures and 
prepared a plan of action for its reform and modernization. A June 2001 FAD mission concluded that significant progress made in implementing the recommendations of the April 2000 mission in recent months, including (1) the adoption of a new tariff nomenclature; (2) the adoption of a presidential decree reducing the scope and clarifying the procedures for the granting of exemptions; (3) the adoption of a new structure for the organization of the SCC; (4) the introduction of a code of conduct; (5) the completion of the first phase of a project to link customs offices by wide area network; and (6) the adoption of a law on customs brokers. Specific measures have also been initiated to promote integrity among staff and improve transparency of procedures. On the other hand, the mission reiterated and updated in its aide-mémoire a number of key recommendations of the FAD April 2000 mission including (1) the appointment of a committee to coordinate reforms; (2) the establishment of a tariff and trade policy committee to deal with the tariff reform; (3) a further review of the scope of exemptions, in particular for those under the Oil Production Sharing Agreements; (4) the streamlining of procedures for reliable traders; and (5) the development of a computer system with function capabilities including valuation checks.

10. In the context of Azerbaijan's new PRGF, it was agreed to issue a tender for an external evaluation of the SCC's organization and procedures. The June 2001 FAD mission helped the authorities in preparing the tender and terms of reference for this evaluation. Once the evaluation of the SCC has been completed by the selected company, it is understood that the government will prepare a reform action plan to be implemented in the context of the PRGF-supported program.

11. The recent move made by the SCC to accelerate the customs reform process and the acceptance of an independent evaluation of its organization and procedures should be interpreted as positive signs of a commitment to reform. The authorities have indicated that they expect further FAD technical assistance to help draw up an updated action plan based on the results of the evaluation.

\section{E. Public Expenditure Policy}

12. In August 2000, an FAD mission visited Azerbaijan to provide advice on continuing public expenditure reforms. The main recommendations of the report were to (1) streamline the government sector and decompress wage scales, (2) improve the targeting of social assistance, particularly in the energy sector, (3) reduce the number of staff in the education sector and spend the savings in the sector on goods and services and wage increases, (4) provide more funding for basic health care, and (5) improve management and evaluation of capital spending projects.

13. In general, progress on public expenditure efficiency was slow, but most of the recommendations in the August 2000 report have now been implemented. Improvements have been made in some areas, ineluding the implementation of a new civil service law that decompresses some wages and increased budgeting for health expenditures. Nonetheless, significantly more effort is needed in this area. 


\section{Monetary and Exchange Affairs Department (MAE)}

14. In recent years, MAE has provided technical assistance through a mix of short- and long-term expert visits, staff visits, and multi-topic missions in the areas of systemic bank restructuring and banking supervision, banking legislation, payments systems reform, and monetary and exchange operations. Technical assistance in bank restructuring, bank supervision, and payment system reform has been closely coordinated with the World Bank. At the authorities' request, MAE and the World Bank assisted in developing a strategy for systemic banking restructuring in late 1999. Substantial progress has been made in carrying out the strategy, but these achievements will need to be consolidated through further structural reforms contemplated under the new Fund program and will require continued technical assistance. In conjunction with the recent internal reorganization of the Azerbaijan National Bank (ANB), MAE has also been providing assistance in central bank accounting standards and policies and internal auditing.

\section{A. Banking Restructuring}

15. From September 1998 through April 2001, advice in this area was provided by a resident advisor in bank supervision and bank restructuring, and supported by advice from headquarters and several MAE missions. A major accomplishment was the development of a comprehensive strategy aimed at the restructuring of the state banks, the private banking system and strengthening the prudential framework for barking in the areas of supervision, payments, accounting, and the underlying legal framework. Substantial progress has been made in implementing the strategy, although important elements remain to be completed.

16. A new peripatetic advisor on banking supervision and restructuring began work in August 2001 . He is to advise on any remaining outstanding restructuring issues as needed and to assist in coordinating the work of World Bank and other experts in this area. Under the work plan developed, he is also assisting in a study of impediments to efficiency and competition in the banking system and the development of a plan to reduce the impediments identified. The ANB has stressed the importance of continued TA in this area in 2002 .

\section{B. Banking Supervision}

17. With the assistance of the resident advisor, 12 new or revised supervisory regulations were developed. The advisor also belped develop a new bank reporting form, consistent with international accounting standards, and tenders will soon be requested for software to computerize the off-site reporting process. The development of the new reporting system was also intensively utilized as a training tool for both off-site and on-site supervisors. In addition, he advised on the development of a bank rating system and on the integration and reorganization of the supervisory function, including the expansion and upgrading of staff through outside recruitment under an improved salary structure.

18. Continued assistance will be needed from the new peripatetic advisor to further refine work in these areas, assist in implementing fully new regulations, and provide training to 
reinforce current skills in techniques for off-site analysis and on-site inspection. The work program for the new advisor (which contemplates visits on roughly a quarterly basis through end-2002) also calls for assistance in further developing capacity for resolving problem banks through training and the development of a manual and procedures for this purpose. The work program includes assistance in conducting a Basel core principles self-assessment and in developing an ongoing internal training program.

\section{Legal Assistance}

19. Advice on revising the current commetcial and central banking laws was provided in the context of an April 1999 MAE mission. However, after further review, the authorities opted to draft a completely new commercial banking law, on which work is currently underway with the assistance of TA jointly supported by MAE and the Legal Department. A major thrust of the new law will be to strengthen the framework for corrective action and bank resolution. The authorities are committed to sending the new draft law to Parliament during its current session and have stressed the importance of continued TA in developing the law. Recently, an MAE expert assessed the legal and regulatory framework for the new payment system and concluded that the framework was currently adequate. Once the new banking law has been passed by Parliament, the authorities will contemplate revising the central banking law and are likely to request assistance for this project.

\section{Payment System}

20. Since May 1997, a payments expert has visited Azerbaijan on roughly a quarterly basis. With his assistance, a long-term payments system strategy was developed and adopted, accounts of banks with branch networks were consolidated, a Real Time Gross Settlements (RTGS) system was implemented (in early 2001), and a service bureau arrangement was developed to integrate into the RTGS system some smaller banks that do not possess the necessary SWIFT technology. The implementation of the RTGS is considered to be an important accomplishment that is expected to substantially reduce operating costs and improve liquidity management of commercial banks. It should also reinforce recent effitorts to improve govenment cash management.

21. Two additional visits are contemplated for this expert to assist in completing work on the planning and procurement of an electronic low value payment system, which would handle both card-based and bulk payments. He will also advise on refining the RTGS operation, implementing RTGS interfaces to the new general ledger accounting system, on matters related to the joint ANB/Treasury Department payment system initiative and possibly on implementing a check clearing process. Since the low value payment system project has been expanded from its original conception, follow-up assistance will likely be needed in 2002. The authorities agree that additional TA in this area will be needed in 2002. 


\section{E. Accounting}

22. In the context of a major intemal reorganization of the ANB, an MAE expert advised on carrying out fundamental changes in the functions and procedares of the Accounting and Reporting Department (ARD). As a result, the ARD has moved from being merely a department for recording and consolidating central bank transactions to assuming full responsibility for determination of ANB accounting policy and procedures. Beginning in 2001, another MAE peripatetic expert has been providing advice on improvements in new accounting standards applying to financial institutions to bring them into conformity with international accounting standards, strengthening of ANB accounting procedures, and the development of a modern central bank budgetary system. The development of new accounting standards and procedures applying to financial institutions will be an important step in producing more reliable information on the soundness of commercial banks. Progress in ANB accounting bas been excellent, in large part due to the bard work of the accounting staff, and the support of senior management. Two more visits are scheduled through early 2002 , but additional support in this area is likely to be needed in 2002. This assessment is shared by the authorities.

\section{F. Internal Auditing}

23. In October 2000, an MAE mission assisted in developing an action plan for making the newly established Internal Auditing Department functional. An MAE expert began peripatetic visits in January 2001. Advice has been provided in developing an internal audit charter; annual work plan, internal questionnaire and audit program in support of audit methodology; and in revising the audits procedures manual. Training has also been provided in auditing strategies, policies, and procedures. While progress was initially slow because of the complete lack of familiarity with, and in-house expertise in, auditing, the ANB staff are become more comfortable with international audit practices, and progress is accelerating. IMF staff and the ANB agree that follow-up assistance will be required in 2002, especially to provide training in specific auditing methodologies and to develop an ongoing training program.

\section{G. Monetary and Foreign Exchange Operations}

24. An April 1999 MAE mission provided advice on improving the functioning of the foreign exchange market and ANB intervention policies, upgrading the design of the relatively limited monetary instruments in use, and strengthening ANB/Treasury coordination to improve the functioning of the treasury bill market. While advice in these areas has been implemented and technical improvements have been made in the treasury bill market, market development has been slow because of the Ministry of Finance's concerns about the interest costs on these instruments and the current absence of large treasury financing needs. A. June 2001 MAE mission examined issues related to the market's further development. 
25. With progress on systemic bark restructuring under way, the authorities are now turning their attention to improving the framework and instruments for monetary and exchange policies and developing financial markets. In this context, a request has already been made for a resident advisor to assist in developing ANB capacity in macroeconomic and monetary analysis and forecasting, an issue that will be revisited in detail by the next MAE mission. Additional assistance will also be required in further improving monetary instruments and the operating framework for monetary and exchange policy.

\section{Statistics DePartMeNT (STA)}

\section{A. Balance of Payments Statistics}

26. Over the period 1995-2001, IMF technical assistance in the area of the balance of payments statistics was provided to the ANB during five balance of payments statistics missions. The missions guided the ANB in its substantial efforts to implement the recommendations of the fifth edition of the Balance of Payments Manual (BPM5), with the result that quarterly balance of payments statements are now published regularly in the $B P M S$ format on a timely basis, and antual international inyestment position (IIP) data will be published in the September 2001 issue of International Financial Statistics (IFS). ANB staff have a thorough knowledge of the BPMS methodology, and have largely implemented the $B P M 5$ recommendations, with the exception of the methodology used for direct investment income associated with large investments in the oil sector.

27. All data sources used to compile the balance of payments and IIP data were examined in detail and it was found that, with the exception of those for foreign direct investment in the oil sector, workers remittances, and compensation of employees, the data sources were generally acceptable, although further improvements are required. The areas of greatest need for improvement are (i) identifying goods for processing in the custom statistics, (ii) augmenting the coverage of transactions in the oil sector, (iii) developing data on migrants' transfers, workers remittances, and compensation of employees, (iv) improving the methodology for compiling external debt, (v) excluding valuation changes from the calculation of transactions in the foreign financial assets of commercial banks, (vi) further development of the International Transactions Reporting System, (vii) improving the quality of the IIP data, and (viii) improving the data on shuttle trade.

\section{B. Real Sector Statistics}

28. During the last three years, Azerbaijan has received 6 technical assistance missions in real sector statistics-three in price statistics, two in national accounts statistics, and one in national accounts and GDDS. The two national accounts statistics missions, conducted in 1999 and 2000, assessed the development of source data, reviewed compilation procedures for annual and sub-annual national accounts, developed a medium-term program for improvement of national accounts estimates and prepared a broad-based quality assessment 
of national accounts estimates. The mission provided specific guidance on issues related to the undervaluation of output in the crude petroleum and gas industry, improvement of estimates of unrecorded activities, valuation adjustment of inventories, and implementation of new activity classification. However, for several economic activities, the source data remain weak. In addition, there continue to be weaknesses in the national accounts calculation methodology, especially in the deflators. The authorities have requested further technical assistance in national accounts statistics, including a resident national accounts advisor.

29. The price statistics missions provided technical assistance in developing a producer price index (PPI) and in revising the consumer price index (CPI). For the new PPI, the missions assisted State Statistics Cornnittee (SSC) staff in the selection of a new sample of enterprises, provided detailed instructions and assistance in the selection of products and specifications for pricing, assisted in the redesign of the of data collection forms, and corrected problems that arose in the weights for the index. The authorities started to publish the new PPI in 2001. The missions also evaluated the CPI (price collection procedures, weights tabulation, sampling of items and outlets, etc.) and assisted the SSC in developing a plan for carrying out a short-term project for the development of a new CPI. The SSC expressed interest in obtaining further technical assistance from the Fund on the PPI and the CPI.

\section{Monetary and Financial Statistics}

30. In November-December 2000 , a monetary and financial statistics mission conducted a thorough review of Azerbaijan's monetary statistics, following the full migration to a 3-digit chart of accounts for the ANB and the introduction of a new 4-digit chart of accounts for other depository corporations. The mission found some methodological weaknesses in the compilation of monetary statistics which affect several monetary and fiscal aggregates. The mission developed new report forms for the ANB and other depository corporations that conform to the methodology of the Fund's Monetary and Financial Statistics Manual (MFSM), and made recommendations to improve the presentation of the analytical accounts of the ANB. The authorities agreed with the mission's recommendations and ate now reporting to the Fund on a regular monthly basis. Additional technical assistance in monetary statistics will be provided after the new 4-digit chart of accounts of the ANB becomes fully operational.

\section{Report on the Observance of Standards and Codes (ROSC)}

31. A mission to prepare the ROSC data module, which will include a quality assessment of all macroeconomic statistics, is on the mission schedule for April 2002. 


\section{IJEGAL DEPARTMENT (LEG)}

\section{A. Fiscal and Tax issues}

32. Beginning in September 1997, LEG assisted the tax authorities of Azerbaijan in drafting the Tax Code, which was enacted in 2000. The enacted Tax Code is comprehensive and includes tax administration provisions as well as normative provisions dealing with all the taxes imposed in Azerbaijan, including income and profit taxes and VAT. The enacted Tax Code basically follows LEG's suggestions. In September 2000, assistance in drafting the implementing regulations for the Tax Code was provided. This TA has not been very effective, as some important recommendations were not followed by the authorities. LEG has not been engaged in further TA on taxation since then, except for some minor comments on interpretation issues relating to the Tax Code, which were communicated through FAD's local expert.

\section{B. Banking Issues}

33. Since early 2001 , LEG has been assisting the ANB in the drafting of a new banking law, in close consultation with MAE. A draft banking law, based on the banking laws of Westem European countries and the banking Directives of the European Union, has been prepared. At the request of the ANB, LEG has also prepared a draft of altemative bank insolvency provisions in the banking law that would replace the general insolvency law that currently applies to banks. There are currently ongoing discussions with the ANB on these two drafts, with a view to consolidating them into one law. It is expected that LEG will continue to provide follow-up assistance to the ANB and other government agencies during the process of converting the draft banking law into text which is consistent with the legal practice of Azerbaijan. It is also possible that ANB will request LEG's assistance to explain the draft banking law to the Azerbaijan parliament.

\section{Technology and General Services DePartment (TGS)}

34. In March and September 1998 TGS staff and an external consultant assisted the National Bank in Baku in the implementation of the Book Entry System for initiating the securities depository and the primary issue auction of government securities in the National Bank. The Book Entry System was one component of an overall payment system reforms project coordinated by MAE staff. A third mission was conducted to Baku in December 1998 to assist in the final customization and implementation of the Book Entry System in the National Bank. TGS has not had any missions to Azerbaijan since 1998 and none are anticipated. 


\title{
INTERNATIONAL MONETARY FUND
}

\author{
AZERBAIJAN REPUBLIC \\ Staff Report for the 2001 Article IV Consultation, First Review Under the Poverty \\ Reduction and Growth Facility, and Request for Waiver of Performance Criterla \\ Supplementary Information
}

Prepared by European $\Pi$ and Fiscal Affairs Departments

Approved by Oleh Havrylyshyn and George Abed

February 6, 2002

This note provides an update on developments in data dissemination and fiscal transparency and reviews the status of recommendations in the November 2000 "Report on the Observance of Standards and Codes - Fiscal Transparency Module". For a description of the suggested reform measures together with institutions and practices refer to the original report. ${ }^{1}$ The authorities have accepted to undertake a comprehensive ROSC exercise and a mission led by the Statistics Department will visit Baku in April 2002.

\section{A. Fiscal Transparency}

A new budget systems law currently under review by the government addresses shortcomings in transparency and accountability of the budget document and budget preparation process. The new law bas been drafted in close collaboration with the Fiscal Affairs department during a technical assistance mission in August 2001. ${ }^{2}$ Its adoption by parliament is a structural benchmark for March 2002 under the current program.

In November 2001 parliament approved a revised law on the Chamber of Accounts giving it the anthority to audit all government bodies including the Oil Fund. Adequate funds have been approved in the budget for 2002 to enable an effective establishment of its operations. A work program for 2002 has been developed in collaboration with experts from the World Bank.

\footnotetext{
I The original report "Azerbaijan Republic - Report on Observance of Standards and CodesFiscal Transparency Module" was issued in December 2000 as SM/00/278.

${ }^{2}$ Developing a Budget Systems, October 2001, P. Desaj and B.K. Chaturverdi.
} 
The proposed adoption of a comprehensive energy sector reform plan marks an important step towards a clearer separation between the public and the private sector. The authorities have agreed to publicly acknowledge the quasi-fiscal activities in the energy sector. Planned reforms will reduce large inefficiencies which have been created through a system of non-payments for utility services. Further efforts will however be needed to disentangle public and private activities in other areas, including by completing the process of removing regulatory functions from state-owned enterprises.

\section{B. Data Dissenination and Reporting}

In June 2001 the government of Azerbaijan subscribed to the General Data Dissemination Standard (GDDS). The Ministry of Finance continues to produce monthly, quarterly and annual reports of fiscal operations on a GFS-based classification. Extrabudgetary funds such as the Oil Fund funds have also begun to provide regular reports. Beginning 2002 transactions of the social protection fund will be executed through the single treasury account which will further enhance its transparency.

\section{Staff commentary}

The imminent adoption of a new budget systems law and the strengthening of the supreme auditing body represent significant reform measures in fiscal transparency. An important remaining weakness in budget transparency is the lack of realistic budget estimates. Reforms would entail the introduction of a systematic revenue forecasting process and improved expenditure management methods. Finally, long term sustainable fiscal policies need to be developed in the context of a medium term expenditure framework. 


\section{INTERNATIONAL MONETARY FUND \\ Public Information Notice}

Public Information Notice (PIN) No. 02/24

FOR IMMEDIATE RELEASE

March 8, 2002
International Monetary Fund

$70019^{\text {th }}$ Street, NW

Washington, D. C. 20431 USA

\section{IMF Concludes 2001 Article IV Consultation with the Azerbaijan Republic}

On February 20,2002, the Executive Board of the International Monetary Fund (IMF) concluded the Article IV consultation with the Azerbaijan Republic. ${ }^{1}$

\section{Background}

On July 2, 2001, the Executive Board approved a new three-year program under the Poverty Reduction and Growth Facility, in an amount equivalent to SDR 80.45 million (50 percent of quota). The first semi-annual loan under this program was disbursed in July 2001 (see Press Release No. 01/33).

Azerbaijan's 2001 economic performance was strong. Real GDP growth is estimated at 9 percent, exceeding the 8.5 percent program target for the year. Both the oil and the non-oil sector, including agriculture, experienced strong growth. Consumer price inflation for the year ending December was 1.3 percent, below the 2001 inflation target in the program of 2.5 percent.

Financial policies remain on track, with money and credit growth somewhat faster than programmed and net international reserves of the Azerbaijan National Bank (ANB) well above program targets. The fiscal deficit was well within program ceilings, notwithstanding a shortfall in revenues. Revenue from state owned enterprises declined due to the switch from prenegotiated tax targets to payments according to the tax code. Expenditures were adjusted by

\footnotetext{
${ }^{1}$ Under Article IV of the IMF's Articles of Agreement, the IMF holds bilateral discussions with members, usually every year. A staff team visits the country, collects economic and financial information, and discusses with officials the country's economic developments and policies. On return to headquarters, the staff prepares a report, which forms the basis for discussion by the Executive Board. At the conclusion of the discussion, the Managing Director, as Chairman of the Board, summarizes the views of Executive Directors, and this summary is transmitted to the country's authorities.
}

Washrngton. 0.C. 20431 * Telephorte 202-623-7100 - Fax 202-523-6772 - whw. mforg | 
reducing expenditures on goods and services and domestically financed investments relative to budget projections.

Throughout 2001, the exchange rate of the manat continued its gradual nominal depreciation. The current account registered a slight deficit in the first half of 2001, compared with a small programmed surplus, as larger than projected service imports more than offset the better than programmed trade balance. Net direct investment increased sharply in the second half of 2001 and is projected to increase further over the medium term, as major energy sector projects are being developed.

On the structural front, reforms continued across a wide range of activities. Progress was made in spelling out rules for Oil Fund asset management and spending. The Customs Committee has been evaluated by an external auditor, and the government has agreed on a reform program on the basis of this evaluation. Steps that were taken to make the Chamber of Accounts operational included appointing a head, submitting a revised law on the Chamber of Accounts to parliament, and inclusion in the 2002 budget of adequate funding for this institution. The ANB eliminated its deposits at the International Bank of Azerbaijan (IBA), thus contributing to the creation of a level playing field in the banking sector. Other important reforms in this sector in 2001 included the revocation of Agroprom's banking license and the adoption of operating principles for the state-owned United Universal Joint Stock Bank.

Combating arrears and non-payments in the domestic energy sector is a key focus of Azerbaijan's economic reform program. In the second half of 2001, a long-term management contract for the Baku Electricity Distribution Network was signed, and the authorities decided to eliminate all preferential consumer tariffs for electricity, gas heating, and transportation effective January 2002. In February 2002, the government adopted a comprehensive plan to strengthen financial discipline in the energy sector. An important element in this plan is the decision to include subsidies to the utility companies in the 2003 budget, and to include these subsidies in quarterly public reports on the execution of the consolidated government budget throughout 2002. The plan also contains a commitment to gradually eliminate the spread between domestic and export prices for oil.

\section{Executive Board Assessment}

Executive Directors commended the authorities for Azerbaijan's continued strong economic performance in 2001, and noted that, despite the slowdown in the international economy and the reduction in oil prices, real GDP growth has been sustained at a high level. The authorities' economic policies contributed to low inflation and a positive consolidated government budget balance. Directors felt that the prospects for broad-based economic growth and low inflation are encouraging. However, in light of the continuing uncertain prospects in the energy sector, Directors stressed that economic diversification over the medium term should remain a crucial policy objective of the authorities in order to sustain a lasting reduction in poverty.

Directors agreed that the authorities' fiscal stance for 2002, which is somewhat tighter than originally envisaged, remains appropriate in the present circumstances. Nevertheless, they 
advised the authorities to carefully monitor revenue developments, and to be prepared to adjust the budget if developments_-particularly those related to the oil sector-tum out to be less positive than currently expected. They also urged the authorities to take steps to improve revenue collections and expenditure management, and welcomed the increase in the share of expenditures going to education, health and social protection.

Directors welcomed the adoption of a comprehensive plan to strengthen financial discipline in the energy sector, noting that failure to reduce the large quasi-fiscal subsidies in this sector would threaten both the economic stability already achieved as well as the further broadening of economic growth. Directors were particularly encouraged by the decision to incorporate into the state budget the subsidies provided by the State Oil Company of the Azerbaijan Republic (SOCAR) to the utility companies, which they consider a crucial step toward fiscal transparency and enhanced financial discipline. Directors emphasized the importance of the authorities' commitment to develop a timetable for the gradual elimination of the spread between domestic and export prices for natural gas, crude oil and oil products.

Directors were encouraged by the adoption of regulations and procedures to ensure the integrated planning, execution and monitoring of the oil fund and state budgets in the context of a consolidated budget. Directors urged the authorities to develop a prioritized Medium Term Expenditure Framework and Public Investment Program to guide the utilization of oil fund assets, stressing that the oil fund, if used wisely, can make a crucial contribution to combating poverty in Azerbaijan.

Directors considered that monetary policy should continue to target a low rate of inflation, and that the exchange rate should remain market-determined. They welcomed the ongoing efforts to strengthen the banking system, including through improved banking supervision and raising the share of foreign banks, and the progress in the rehabilitation of the state-owned United Universal Bank. They encouraged the authorities to complete the privatization of the IBA in order to create a competitive banking system in Azerbaijan. Directors praised the measures the authorities have taken to eliminate funding sources for international crime and to prevent money laundering.

Directors commended the authorities for the progress made in improving governance in 2001. with the expansion of the authority of the Chamber of Accounts, the passage of an improved procurement law, and the commitment to public reporting and auditing of the activities of the oil fund. Directors also welcomed the completion of the external evaluation of the Customs Committee and the adoption of a reform program on the basis of that evaluation, and encouraged the authorities to move forcefully with its implementation.

Directors noted the progress made in the preparation of the Poverty Reduction Strategy Paper, and urged the authorities to make every effort to develop a high-quality poverty reduction strategy in a fully participatory manner.

Directors stressed the need to improve macroeconomic and social data. They welcomed the steps that the authorities have taken in this regard in recent years, and urged them to continue 
their efforts to strengthen the statistical system and to ensure the timely dissemination of statistics. Directors welcomed the authorities' intention to accept the obligations of Article VIII, Sections 2,3 , and 4 .

Public Information Notices (PINs) are issued, (i) at the request of a member country, following the conclusion of the Article IV consultation for countries seeking to make known the views of the IMF to the public. This action is intended to stren gthen IMF surveillance over the economic policies of member countries by increasing the transparency of the IMF's assessment of these policies; and (ii) following policy discussions in the Executive Board at the decision of the Board. The Staff Report for the 2001 Article IV Consultation with Azerbaijan is also available. 
Azerbaijan: Selected Economic Indicators

\begin{tabular}{|c|c|c|c|c|c|}
\hline & 1997 & 1998 & 1999 & 2000 & $\begin{array}{l}2001 \\
\text { taff Est. }\end{array}$ \\
\hline & \multicolumn{5}{|c|}{$\begin{array}{c}\text { (Percentage change, unless otherwise } \\
\text { indicated) }\end{array}$} \\
\hline $\begin{array}{l}\text { GDP (in billions of manats) } \\
\text { Real GDP }\end{array}$ & $\begin{array}{r}15,791 \\
5.8\end{array}$ & $\begin{array}{r}17.203 \\
10.0\end{array}$ & $\begin{array}{r}18,875 \\
7.4\end{array}$ & $\begin{array}{r}23,565 \\
11.1\end{array}$ & $\begin{array}{r}26,494 \\
9.0\end{array}$ \\
\hline $\begin{array}{l}\text { Consumer price inflation (average) } \\
\text { Nominal manat wage (average) }\end{array}$ & $\begin{array}{r}3.7 \\
58.5\end{array}$ & $\begin{array}{l}-0.8 \\
18.9\end{array}$ & $\begin{array}{r}-8.5 \\
9.5\end{array}$ & $\begin{array}{r}1.8 \\
20.2\end{array}$ & $\begin{array}{r}1.5 \\
26.4\end{array}$ \\
\hline $\begin{array}{l}\text { Exports of goods (US\$ million) } \\
\text { Imports of goods (US\$ million) } \\
\text { Current account balance (US } \$ \text { million) } \\
\text { Current account balance (in percent of GDP) }\end{array}$ & $\begin{array}{r}808 \\
1,375 \\
-916 \\
-23.1\end{array}$ & $\begin{array}{r}678 \\
1,724 \\
-1,364 \\
-30.7\end{array}$ & $\begin{array}{r}1,025 \\
1,433 \\
-600 \\
-13.1\end{array}$ & $\begin{array}{r}1,877 \\
1,539 \\
-124 \\
-2.4\end{array}$ & $\begin{array}{r}2,025 \\
1,457 \\
-134 \\
-2.3\end{array}$ \\
\hline $\begin{array}{l}\text { Consolidated Government (percent of GDP) } \\
\text { Total revenue } \\
\text { Total expenditure (including net lending) } \\
\text { Fiscal balance (- deficit) }\end{array}$ & $\begin{array}{l}19.1 \\
20.8 \\
-1.6\end{array}$ & $\begin{array}{r}19.6 \\
23.7 \\
-3.9\end{array}$ & $\begin{array}{l}18.5 \\
23.6 \\
-4.7\end{array}$ & $\begin{array}{r}21.2 \\
20.9 \\
-0.6\end{array}$ & $\begin{array}{r}21.4 \\
20.0 \\
1.5\end{array}$ \\
\hline $\begin{array}{l}\text { Manat reserve money, end of period } \\
\text { Manat broad money, end of period }\end{array}$ & $\begin{array}{l}35.6 \\
29.2\end{array}$ & $\begin{array}{l}-22.3 \\
-10.6\end{array}$ & $\begin{array}{r}20.9 \\
5.3\end{array}$ & $\begin{array}{l}22.1 \\
11.1\end{array}$ & $\begin{array}{l}9.0 \\
9.8\end{array}$ \\
\hline $\begin{array}{l}\text { Exchange rate (manat/US\$, end of period) } \\
\text { Exchange rate (manat/US\$, period average) }\end{array}$ & $\begin{array}{l}3,888 \\
3,985\end{array}$ & $\begin{array}{l}3,890 \\
3,869\end{array}$ & $\begin{array}{l}4,378 \\
4,126\end{array}$ & $\begin{array}{l}4,565 \\
4,472\end{array}$ & $\begin{array}{l}4,775 \\
4,655\end{array}$ \\
\hline
\end{tabular}

Source: Azerbaijan State Committee on Statistics, Azerbaijan National Bank, Ministry of Finance; and IMF staff estimates. 


\section{Stutement by Roberto F. Cippà, Executive Director for the Azerbaijan Republic February 20, 2002}

My authorities would like to express their gratitude for the very constructive role the Fund staff has been playing in the formulation of macroeconomic policies in Azerbaijan over the last few years. For this review in particular, the good cooperation between the staff and the authorities has resulted in a comprehensive package of measures which will be instrumental in pushing forward the transition process of the Azeri economy. This is especially true in the energy sector, where the authorities have adopted a thorough reform program aimed at improving financial discipline. During the discussions about this reform program, the staff made clear what its objectives should be. At the same time, the staff kept an open mind as to how these objectives could be reached. This commendable approach allowed the authorities to come up with their own measures in order to reach these objectives. The result is an ambitious but realistic reform program with an exemplary degree of ownership.

Macroeconomic developments in 2001 were very positive with economic growth higher and inflation lower than projected. In terms of policy performance and program implementation, the authorities' record over the review period has been very encouraging. The waivers the authorities are requesting are due to relatively minor breaches of performance criteria which have been swiftly corrected.

\section{Fiscal policy and Energy Sector}

With regard to fiscal policy in 2001 , the stance was more restrictive than programmed. The authorities reacted to a modest revenue shortfall by promptly reducing expenditure, avoiding accumulating arrears. For 2002, the authorities have taken a number of important decisions in the fiscal area. Most importantly, they have formulated a program to enhance the financial discipline in the energy sector which has the potential to positively affect Azerbaijan's economy in a major way. While it is true that the energy sector program was expected to be formulated by end-September 2001, the complexity of the undertaking was probably underestimated at the outset. In any case, the delay until January this year gave the authorities the necessary lime to define, in close cooperation with the staffs of the Fund and the World Bank, measures which are both adequate and realistic.

The urgency of this program lies in the fact that a lot of resources in the energy sector are lost due to inefficiencies and wrong incentives. In order to show the magnitude of the problem to the Azeri people, the government has decided to publish the amount of the implicit state subsidy to the energy sector during the two last years, as well as the projected subsidy for this year. Starting in the first quarter of 2002 , the quarterly reports on the consolidated government budget will contain the amount of the subsidy which is provided by the State Oil Company (SOCAR) to Azerenergy and Azerigas. In return, SOCAR will be granted tax credits in the same amount. From 2003 onward, the subsidies will be formally incorporated into the state budget. With these measures, the government intends to demonstrate to the public that the current subsidies to utility consumption are too heavy a burden for the state. 
Pointing to their opportunity cost, the government will then be in a reasonably strong position to implement the ambitious reform program to enhance financial discipline in the energy sector.

Beside the inclusion of subsidies in the budget reports and, eventually, the budget itself, the energy sector program contains a wide number of measures, detailed in the Letter of Intent. Overall, these measures are designed to generate higher payments by budgetary organizations, state-owned enterprises and households, to make utility producing and consuming companies more efficient, to speed up privatization in the energy sector, and to gradually unify domestic with world market energy prices.

\section{Monetary and Exchange Rate Policies}

Monetary policy has been sound in Azerbaijan for the last several years. Over the review period, monetary developments have been well in line with the program and all quantitative performance criteria for end-September 2001 were met. With respect to the exchange rate, the ANB is intending to continue its policy of managed floating. The authorities are aware that, over the medium term, there is a need to consider the exchange rate policy in view of the expected increase both in oil fund expenditures as well as in oil sector revenues.

\section{Structural Policy}

As pointed out by the staff, the track record of structural reform in the last two years has been impressive. All measures subject to performance criteria have now been implemented and strong progress is continuing in a number of areas. In the banking sector, measures are being taken based on diagnostic studies of commercial banks done last year. In particular, five banks were closed, and both the minimum capital requirement and the limit on foreign ownership of domestic banks have been increased. The authorities are committed to eliminate the current limit of foreign ownership at the end of 2002 . Furthermore, the new Banking Systems Law will be submitted to parliament shortly. Regarding the technical violation of a performance criterion due to delays in the elimination of deposits in nonconvertible currencies from the International Bank, it has to be noted that the amounts were very small and that the accounts were closed shortly after the deadline.

The authorities recognize the importance of advancing good governance. They therefore took a number of decisions such as strengthening the Chamber of Accounts, passing an improved procurement law, developing an anti-corruption law and accelerating the privatization process. In this respect, the non-observance of the performance criterion on adopting the revised law on the Chamber of Accounts was minor in our view. This law was submitted to parliament just a few weeks later than envisaged and contains all the crucial elements. Moreover, the draft 2002 budget includes adequate funds that will enable the Chamber of Accounts to implement its new responsibilities quickly. In the area of tax administration, it is impottant to note that the government has abolished the practice of negotiating tax payments for large state-enterprises and that all taxpayers are now required to pay taxes based on their legal obligations. 
Regarding the Customs Committee, the delay was due to factors beyond the authorities' control. Since the Azeri law requires at least three bidders for a tender to be valid, the tender had to be rerun in order to obtain enough bids. However, the evaluation has now been completed and based on it a Customs Committee reform program has been adopted in January. Crucial elements of this program include better data collection and control, revenue enhancement, trade facilitation, and greater accountability and efficiency of customs administration.

\section{Technical Assistance Consultations}

Technical assistance (TA) provided by the Fund has generally been well received and successfully implemented. The authorities would like to express their gratitude for the professional and efficient TA Azerbaijan has been receiving from the Fund. They particularly appreciate the efforts of the resident advisors in the Treasury of the Ministry of Finance and the ANB as well as the technical long-term advisor for tax administration. Based on an assessment of their needs, the authorities believe that continuous TA will be most productive in the areas of fiscal and monetary policy capacity building. Furthermore, my authorities look forward to the mission scheduled for April which will assess the quality of macroeconomic statistics. Being mindful of the need of improvements in this area, they hope that the Fund would satisfy the request for a resident national accounts statistics advisor.

My authorities recognize that some of the delays occurring in program implementation were due to a lack of a systematic monitoring of the overall reform efforts. They have therefore decided that representatives of the relevant government agencies will meet on a monthly basis to review the implementation progress under the program. Based on this meetings, monthly reports on program implementation will be prepared for consideration by the Prime Minister.

To conclude, let me stress again that Azerbaijan has made significant economic progress during the review period. Despite some implementation delays, the program is on track and risks have been reduced. My authorities are grateful to the Fund for contributing to this success and look forward to continuing the fruitful cooperation. 